Minoru Naruto

\title{
Repensar a formação do arquiteto
}

Tese apresentada à Faculdade de Arquitetura e Urbanismo da Universidade de São Paulo para obtenção do título de Doutor em Arquitetura Urbanismo

Área: $\quad$ Estruturas Ambientais Urbanas

Orientador: Dr. Khaled Ghoubar

São Paulo 2006 
Autorizo a reprodução e divulgação total ou parcial deste trabalho, por qualquer meio convencional ou eletrônico, para fins de estudo e pesquisa, desde que citada a fonte.

E-mail: naruto@terra.com.br

Naruto, Minoru

N237r Repensar a formação do arquiteto / Minoru Naruto. -São Paulo, 2006.

129 p.: il.

Tese (Doutorado - Área de Concentração: Estruturas Ambientais Urbanas) - FAUUSP.

Orientador: Khaled Ghoubar

1.Arquitetura - Estudo e Ensino 2.Projeto de Arquitetura Estudo e Ensino I.Título

CDU $\quad 72: 37$ 


\section{Agradecimento}

Aos alunos, colegas e amigos com quem compartilhei as reflexões aqui registradas.

À minha esposa, participante das mesmas buscas e inquietações.

E, sobretudo, ao meu orientador, Professor Doutor Khaled Ghoubar, pela confiança e liberdade que imprimiu à sua orientação e, ainda, à forma independente com que permitiu que esse trabalho fosse desenvolvido. 


\title{
Resumo
}

NARUTO, Minoru. Repensando a formação do arquiteto. 2006. 129 p. Tese (Doutorado) - Faculdade de arquitetura e Urbanismo da Universidade de São Paulo, São Paulo, 2006.

O ensino institucional da arquitetura no Brasil é considerado insatisfatório de forma quase consensual. Tem sido objeto de inúmeras e continuadas reformulações em sua curta história de pouco mais de seis décadas, sem contudo se obter maiores avanços. Este trabalho reconstitui o processo dessas reformas centrado nas experiências da FAUUSP, muitas das quais tiveram papel decisivo na organização dos cursos da maioria das escolas do país. O autor vivenciou em parte esse processo e analisa algumas questões e propostas que considera importantes para a reflexão sobre a questão. A partir da hipótese de que o problema do ensino da arquitetura é, na realidade, problema do ensino do projeto, analisa o conflito conceitual e organizacional entre o ateliê, considerado locus privilegiado para o ensino de projeto, e a estrutura disciplinar em que está inserido. Este conflito estaria, aparentemente, na raiz da persistência do problema do ensino do projeto, apesar das sucessivas reformulações. O trabalho procura aprofundar estas e outras questões consideradas importantes para um encaminhamento mais conseqüente do problema.

Palavras-chave: Ateliê. Ensino de arquitetura. Ensino de projeto. Disciplina. Disciplinaridade. FAUUSP.

\begin{abstract}
NARUTO, Minoru. Rethinking the development of the architect. 2006. 129 p. Thesis (Doctor's degree) - Faculty of Architecture and Urbanism - São Paulo University, São Paulo, 2006.

The institutional training of architecture in Brazil is deemed unsatisfactory on an almost consensual level. It has been the target of many and continuous reformulations along his short existence - a little more than six decades - but nevertheless it has not achieved much advancement. This thesis aims to reestablish the process of these reforms, centered in the experiences of the FAUUSP, many of which have played a crucial part in the organization of the courses offered in the majority of architecture faculties in the country. Its author has partly experienced this process and analyses some issues and proposals which, in his opinion, are important for a meditation on that matter. Adopting the assumption that the problem of the teaching of architecture is, in fact, a problem of the teaching of design, this author analyses the organizational and conceptual conflict between the atelier, seen as the privileged locus for the teaching of design, and the disciplinary structure in which it is embedded. Apparently this conflict would be in the root of the problem of the persistency of the teaching of design, notwithstanding its successive reformulations. The thesis looks up to deepen this and other issues, seen as important for a more consequent forwarding of the problem.
\end{abstract}

Key words: Atelier. Teaching of architecture. Teaching of design. Discipline. Disciplinarity. FAUUSP. 


\section{Sumário}

Introdução 11

1. Ensino de arquitetura no Brasil hoje 17

$\begin{array}{lll}1.1 & \text { A escola autônoma de arquitetura } & 18\end{array}$

1.2 Panorama das reformas 22

1.3 Fases e modelos 28

1.4 Os modelos de ensino 32

2. As reformas da FAUUSP 38

2.1 ateliê como estratégia 41

2.2 A reforma de $1957 \quad 43$

2.3 As manifestações 45

2.4 Relatório "Roberto de Cerqueira Cezar" 48

2.5 Comissão de Estudo do Ateliê 50

2.6 A "Reforma de 62" 53

2.6.1 Os departamentos 54

2.6.2 Departamento de Projeto 55

2.6.3 O ateliê de 62

2.64 Trabalho de graduação $\quad 59$

2.7 O "Fórum de 68" 62

2.8 A Reforma Universitária 67

3. FAUUSP após a Reforma Universitária 71

3.1 O Fórum de 78" 72

3.1.1 A integração proposta $\quad 72$

3.1.2 A integração na prática 76

3.2 A reestruturação de $97 \quad 81$

3.2.1 Reafirmação da arquitetura 83

3.2.2 Racionalização dos recursos 87

3.2.3 Aproximação à realidade 88

3.3 Conclusão do capítulo 89 
4. O ateliê e a disciplina 91

4.1 O ateliê da FAUUSP 92

4.2 Tese de graduação 96

$\begin{array}{lll}4.3 & \text { Optativas de } 97 & 97\end{array}$

$\begin{array}{lll}4.4 & \text { A questão } & 104\end{array}$

5. Disciplinaridade ou o poder disciplinar 105

5.1 O poder disciplinar 106

$\begin{array}{lll}5.2 & \text { Disciplinaridade e projeto } & 116\end{array}$

$\begin{array}{ll}\text { Conclusão } & 120\end{array}$

Referência bibliográfica 123

$\begin{array}{ll}\text { Bibliografia } & 127\end{array}$ 


\section{Apresentação}

O presente trabalho constitui o resultado de uma pesquisa gerada pela necessidade de referenciar a participação do autor no processo de reformulações do ensino da FAUUSP, onde é professor do Departamento de Projeto desde 1977 e onde foi aluno entre 1964 e 1968. Nessas condições, vivenciou as várias reformas que a escola promoveu em seu ensino.

O interesse pelo assunto foi crescendo à medida que o autor foi se integrando ao esforço coletivo para superar as dificuldades e os problemas que interferiam no ensino do seu departamento e de toda a escola.

Já no ano seguinte ao seu ingresso como docente, participou ativamente no processo que resultaria numa das reformas mais marcantes implantadas na FAUUSP. Passou também a fazer proposições no sentido de contribuir para o encaminhamento de alguns problemas mais prementes. Uma das primeiras propostas, elaborada em conjunto com as demais professoras da equipe, introduziu questões da visualidade tridimensional e espacial, mais pertinentes à arquitetura, no conteúdo da disciplina ministrada para a turma de alunos ingressantes, até então dedicado à linguagem visual bidimensional.

Posteriormente, foi solicitado a orientar os trabalhos de graduação, mantida a alocação no primeiro ano, o que abriu a possibilidade de aferir, ainda que informalmente, o progresso obtido pelo aluno em seus cinco anos do curso. Nessa condição, era também possível ter acesso a suas apreciações sobre o curso, o que permitiu conhecer melhor o quadro geral do ensino na escola. 
A sensação que ia se firmando nesse percurso era de que os resultados demonstrados pelos alunos ficavam, na maioria das vezes, muito aquém daqueles pretendidos pelo projeto didático-curricular existente. Muitos apresentavam dificuldades no projetar, exatamente a habilidade que 0 departamento tinha como responsabilidade exercitar. Alguns pouco conheciam a natureza do objeto para o qual estavam elaborando os projetos solicitados; outros, tinham o meio - o projeto - como a finalidade da arquitetura; muitos tinham dificuldades em representar seus projetos, isso quando conseguiam. Enfim, o departamento falhava em seus objetivos intrínsecos, mesmo considerando a cultura da escola em valorizar a liberdade do alunado na organização de sua formação.

No entanto, da parte dos professores não havia um posicionamento claro sobre a situação do ensino na escola. Havia até dúvidas se realmente havia problema dessa natureza no departamento. Entretanto, era inegável que muitos de nós não estávamos satisfeitos com o ensino do departamento e também com o nosso próprio desempenho como docentes, apesar do esforço e envolvimento pessoais. Percebíamos claramente que havia problemas, mas tínhamos dificuldade em objetiválos e encaminhá-los. .

O fato é que, salvo exceções, os professores do departamento não tínhamos formação pedagógica - nem isso é exigido para o ingresso na carreira - e, tampouco, a considerávamos importante ou necessária para o ensino de arquitetura, em especial para o ensino de projeto. A crença generalizada era de que para isso seria suficiente nossa experiência de projeto em trabalhos profissionais práticos e o fato de termos sido alunos da faculdade. Assim, não tínhamos como não reproduzir automaticamente a forma de ensino que havíamos recebido, embora os tempos, meios e formação anterior dos alunos tivessem mudado drasticamente. 
Assim, estávamos pouco preparados para buscar soluções mais conseqüentes para os problemas de ensino que se avolumavam, tanto no departamento a que pertencíamos quanto em toda a escola.

Na primeira experiência de reformulação, da qual o autor participou como docente - o Fórum de 1978 - e que dizia respeito à grade curricular de toda a escola, a decisão aprovada imaginou resolver o problema da fragmentação do currículo, considerado consensualmente como a causa da degradação do ensino da escola. Entretanto, o resultado prático da reforma foi exatamente o oposto ao que visou a proposta: aumentou a fragmentação.

Na segunda experiência, em 1997, a reforma se restringiu ao Departamento de Projeto, até porque cada vez mais se firmava a idéia de que o problema de ensino de arquitetura era o problema de ensino de projeto.

O que começou a ficar mais evidente no desenrolar dessa nova experiência, confirmou, de forma mais comprometedora, o que havia sucedido no Fórum de 78: as propostas apresentadas, aliás em número significativo - da mesma maneira que as do encontro anterior -, não explicitavam claramente as premissas e os conceitos que as fundamentavam. Era patente a dificuldade para discuti-las e avaliá-las de uma forma objetiva e conseqüente: as propostas eram objeto de interpretações diversas, porque não havia uniformidade no entendimento de seus objetivos e premissas, bem como nas acepções dadas aos conceitos que circulavam nos debates e nas decisões que se tomavam. $O$ resultado foi um pesado desgaste de grande número de professores e alunos que participaram do processo, o qual se estendeu durante cinco longos anos.

Por outro lado, as mesmas razões que geraram as dificuldades conceituais para sua discussão e aprovação, podem ter prejudicado a implantação da proposta: medidas com reais potencialidades deixaram de 
ser implantadas ou o foram parcialmente, ou ainda, de forma diversa da concepção original e, sendo assim, não alcançaram os resultados imaginados, provavelmente em razão dessa interpretação imprecisa ou incorreta de seus termos.

O fato é que, a reestruturação não alcançou os resultados esperados, apesar de alguns importantes avanços obtidos, como a redução do número de disciplinas e de propostas, não implementadas, como a das disciplinas optativas reconceituadas.

Uma das hipóteses centrais para o insucesso de mais essa reforma, e também de muitas das reformulação do ensino de arquitetura em geral, parece ser o fato de que há uma questão de caráter estrutural até hoje não objetivada e que se revela na incompatibilidade entre o caráter eminentemente integrador da atividade de projeto e o caráter desintegrador da organização disciplinar do conhecimento e do ensino universitário modernos. Essa é a razão pela qual a pesquisa, neste trabalho, aprofundou a questão da disciplinaridade envolvida no ensino de projeto.

De qualquer maneira, o que restou é que, não só mais um esforço para a melhoria do ensino está se perdendo, ou já se perdeu, e está se encaminhando para mais uma tentativa de reformulação.

De fato, o Departamento de Projeto está, no momento, organizando mais uma reestruturação curricular e didática, num nível muito além do que previam os mecanismos de revisão incluídos na proposta questionada. Se essa tentativa é bem-vinda como mais uma expressão da cultura crítica, já tradição na Faculdade, por outro lado, não se pode deixar de externar a preocupação de se estar iniciando mais um passo de um "andar em círculos repetindo e revisitando propostas e criações já gastas", em meio à "névoa e à poeira que se depositaram sobre o ensino da arquitetura"1.

\footnotetext{
${ }^{1}$ Arquiteta Maria Argentina de Oliveira Bibas Naruto (manuscrito).
} 
A interpretação dos fatos, como apresentado acima, tem caráter pessoal e certamente subjetivo. A consciência dessa limitação foi um motivo importante que levou o autor a propor como tema de pesquisa a questão da formação do arquiteto.

Tentar entender de maneira mais objetiva os acontecimentos, identificar os prováveis fatores que emperraram as reformas elaboradas e implantadas com muito custo, precisar alguns conceitos, na esperança de que esse esforço - o qual, de qualquer maneira seria empreendido como uma necessidade pessoal - possa ser de alguma utilidade para se repensar o ensino de arquitetura. 


\section{Introdução}

"Formar arquiteto. Formar-se arquiteto" é o título da pesquisa que embasou o presente trabalho. A pesquisa foi proposta pela crescente conviç̧ão quanto à necessidade de refletir e compreender não só as razões dos escassos resultados práticos das sucessivas reformulações do ensino de arquitetura no Brasil e, em especial, na FAUUSP mas, principalmente, as razões das dificuldades que sempre marcaram e prejudicaram os processos coletivos de discussão e elaboração das propostas.

A vivencia direta dos processos mais recentes das reformulação do ensino na FAUUSP, especificamente a de um departamento formalmente responsável pelo "ensino" de projeto, tradicional vertente distintiva do ensino de arquitetura, constituíram campo fértil e rica fonte para essa reflexão.

Ainda que essa vivência tenha se desenvolvido no âmbito de uma escola em particular, era claro que o problema da formação do futuro arquiteto não era específico dessa escola. Ao contrário, tinha-se a nítida compreensão de que não só era um problema que afetava a maioria das escolas de arquitetura de todo o Pais, mas um problema que acompanhou a própria história da curta trajetória de formação institucionalizada do arquiteto brasileiro, iniciada nos meados dos anos quarenta. E da mesma forma que na FAUUSP, muitas outras escolas desenvolveram discussões e propostas, implantadas ou não, com preocupações muito próximas, na busca de soluções problema. Em sendo comuns os problemas e, em decorrência, poderiam ser os obstáculos e as causas da ineficácia das propostas 
A escolha de restringir o universo de análise em torno da FAUUSP se deu não só pelo fato de aí ter sido aluno e de fazer parte de seu quadro docente, o que propiciou a convivência direta dos fatos - circunstância que pode ser considerada favorável desde que devidamente objetivada -, mas também porque a escola tem acumulado ao longo de sua curta história um conjunto paradigmático de questões sobre o ensino, que muitas vezes acabou por levar a visão ou a "cultura" local para além de suas fronteiras.

Mesmo considerando que a constante revisão do ensino de arquitetura seja reflexo e exigência da própria natureza prática e dinâmica da profissão, pode se lançar a hipótese de que a ineficácia de tais tentativas provavelmente teriam sido decorrência de apreensões e compreensões inadequadas ou insuficientes dos problema considerados.

Assim, a partir de um conjunto considerado significativo dessas experiências, organizadas em torno do percurso trilhado pela FAUUSP e informado por casos considerados importantes de outras instituições, é se propôs a identificar e analisar essas dificuldades.

\section{A pesquisa}

Como foi antecipado, a pesquisa constituiu basicamente dedicada à sistematização da reflexão conceitual necessária para subsidiar uma participação ativa no processo de seguidas reformulação do ensino da escola ao qual pertence o autor, na condição de docente e pesquisador e, tambeem de ex-aluno.

Nessa medida, essa "pesquisa" se inicia praticamente com o ingresso do autor na instituição em 1977, aliás, em meio aos preparativos para a o 
tradicional Fórum da $\mathrm{FAU}^{2}$, realizado no ano seguinte, e cujo objetivo era exatamente implementar a reformulação do ensino da escola como um todo.

Por outro lado, embora tendo ingressado na FAUUSP como auxiliar de ensino de grupo de disciplinas denominado "programação visual" do Departamento de Projeto, considerado uma "linha auxiliar" em relação ao projeto de edificações e ao planejamento urbano e territorial, a condição de arquiteto formado na própria escola e a diversificada experiência prática cobrindo desde artes gráficas, edificações, mobiliário e desenho urbano, propiciaram ao autor base adequada para acompanhar e participar dessas e de outras discussões sobre o ensino .

Deve ser considerado importante o fato de o autor integrar o quadro docente do Departamento de Projeto, que constitui locus privilegiado para a reflexão sobre o ensino de arquitetura porque se ocupa justamente da atividade central do arquiteto, o projeto. Nessa condição, não é difícil confirmar, por exemplo, a constatação de que o problema do ensino da arquitetura se superpõe ao problema do ensino de projeto.

Ao lado do engajamento ativo no processo de discussão e reformulação do ensino - Fórum de 1978, seminários de reestruturação da FAU, 1986; reestruturação do Departamento de Projeto, 1992 -, foram importantes como fonte de dados e reflexão, as atividades burocrático-didáticas assumidas em diversas instâncias da estrutura acadêmica, como Congregação, Comissão de Graduação, Conselho do Departamento de Projeto, Comissões de Exames de Habilidades Específicas e de transferências de alunos (Fuvest), Câmara de TFG (Trabalho Final de Graduação) e sobretudo nas atividades didáticas desenvolvidas, entre outras, com as turmas ingressantes e egressantes, que constituem referenciais importantes para a avaliação do desempenho do curso.

\footnotetext{
${ }^{2}$ Fórum é o espaço institucional tradicional da FAUUSP para decisões mais importantes.
} 
Interessante foi igualmente a experiência didática em uma universidade privada como termo de comparação com a experiência da FAUUSP.

A experiência mais importante foi a reestruturação do Departamento de Projeto iniciada em 1992 como retomada das discussões dos seminários de 86. No entanto, a falta de apoio mais direto da direção e sem a adesão dos demais departamentos, as discussões ficaram limitadas apenas ao âmbito do departamento.

Para não repetir o insucesso das tentativas anteriores e, buscando assegurar uma proposta mais conseqüente, tinha-se como essenciais a mais ampla participação alunos e dos professores do departamento e também o esgotamento de toda discussão, o que demandava um cronograma praticamente em aberto. Na prática, isso significou um período de desgastantes seis anos para a aprovação e implantação da chamada reestruturação curricular-didático do departamento.

Dessa forma, ao longo de toda a "pesquisa" que, como já mencionado, não é senão o tempo de casa do autor, foi necessário, de uma parte, buscar um subsídio conceitual consistente para lastrear não apenas a prática acadêmica pessoal mas também para a crítica e esforço visando a mudança da estrutura e das condições em que esta prática estava inserida.

Se de uma parte, a prática didática constituía fértil fonte de dados e exigia continuada pesquisa e reflexão conceitual alimentada pela pesquisa bibliográfica, e troca de idéias com colegas, estudantes e funcionários, de outra parte, ao mesmo tempo, constituía espaço de aplicação e discussão coletiva das conclusões dessa reflexão pessoal e também de avaliação e crítica das propostas de reformulações implantadas.

É importante assinalar que a implantação da reestruturação do Departamento de Projeto a partir de 1998 não significou a suspensão do processo de discussão sobre o ensino na FAUUSP e no próprio departamento. O Departamento de Tecnologia implementou a sua 
reestruturação anos depois e o Departamento de Projeto acha-se em franca atividade visando uma nova reformulação.

Hipóteses

Como resultado da pesquisa, se configuraram algumas hipótese que $\circ$ trabalho tenta confirmar.

Em primeiro lugar, é que a compreensão insuficiente dos problemas tratados tem comprometido a eficácia das propostas, tanto na sua formulação quanto na sua implementação.

A hipótese central é a de que, tanto o êxito de algumas propostas de reformulação quanto o insucesso de outras, compartilham problemáticas semelhantes senão comuns, e que elas têm origem na forma disciplinar que rege a organização do ensino de arquitetura e, especificamente, o ensino do projeto e, principalmente a organização do conhecimento como um todo.

Dos capítulos

O Capítulo I mostra o cenário de continuadas reformulações do ensino de arquitetura no Brasil, desde a sua institucionalização a partir das duas matrizes então existentes, na década de quarenta: a dos arquitetos da tradição das belas artes e a dos engenheiros-arquitetos da tradição das politécnicas. Os primeiros esforços foram no sentido de construir um projeto de ensino em paralelo à consolidação da profissão, num quadro de franco crescimento da demanda profissional. Num segundo momento, emerge, após os anos de resistência das universidades ao regime militar, uma fase de acomodação à nova realidade educacional imposta pela Reforma Universitária de 1968. Finalmente, as transformações exigidas pelas pressão da globalização. 
O Capítulo II inicia a análise das reformas mais significativas da FAUUSP, focalizando desde os movimentos que precederam a primeira reforma em 1962 até a reestruturação do Departamento de Projeto em 1997. Foram considerados ainda o fórum de 1968 e o de 1978. Nesse processo, foi explicitada a gradativa degradação do ensino de projeto, paradoxalmente agravada pelo Fórum de 1978, até a tentativa de sua reversão em 1997.

No Capítulo III, se analisaram as experiências consideradas as mais importantes entre as reformas da escola: o resgate e a valorização do ateliê como espaço por excelência do ensino de projeto, em 1962; a implantação da tese de graduação, em 1968; e a reconceituação das disciplinas optativas como espaço não disciplinar, em 1997. Nessas análises foi possível identificar o que seria a questão central do problema do ensino de arquitetura: o conflito entre as exigências específicas do ensino de projeto e a forma de organização disciplinar do ensino vigente na FAUUSP, e de resto na própria universidade e na própria organização do conhecimento.

No Capítulo IV, se analisa a questão da disciplinaridade, sua natureza e os aspectos que interferem no ensino e na exercitação do projeto de arquitetura. 
1 Ensino de arquitetura no Brasil hoje 


\subsection{A escola autônoma de arquitetura}

Por que falar novamente em ensino de arquitetura se as escolas e os profissionais têm se ocupado continuadamente desse problema? Críticas, hipóteses e argumentos os mais diversos são mobilizados e discutidos por profissionais, acadêmicos e a sociedade; pedagogias e currículos são reformulados, novos cursos propõem métodos e currículos inovadores, propostas mais ou menos drásticas são implantadas e em seguida contestadas e novamente reformuladas. Há, pois, necessidade real de retomar, mais uma vez, ao problema?

Certamente que sim, porque esse movimento incessante de mudanças demonstra exatamente que, para além do próprio dinamismo da arquitetura como prática social e, apesar das incontáveis tentativas, existem problemas específicos de ensino de arquitetura que não estão sendo satisfatoriamente encaminhados. Não que se acredite que existam soluções definitivas ou algum padrão universal válido para o ensino de arquitetura e para todas as escolas, mas o fato é que as propostas e experiências não têm conseguido responder ao que foi percebido como problema e sequer formular uma dinâmica de constante avaliação face à evolução vertiginosa não só dos meios de produção do espaço do espaço arquitetônico como da própria sociedade como sistema cultural e econômico.

Cabe observar, por outro lado, que essa preocupação com o ensino de arquitetura não surgiu somente após e no interior das modernas escolas autônomas brasileiras, criadas a partir da década de 40 .

Com efeito, o ensino especializado e autônomo sempre constituiu instrumento estratégico no processo de afirmação e domínio das profissões e ocupações em geral. Não foi diferente no caso do resgate da 
arquitetura como profissão no País, iniciado com a fundação da associação profissional em 1921.

Conforme registrou Miguel Pereira, mesmo antes da institucionalização dessas escolas, já em 1930 Lucio Costa exigia como condição para aceitar o convite do Governo para dirigir a Escola de Belas Artes do Rio de Janeiro - onde funcionava um curso de arquitetura - "mudar, radicalmente, não só a organização, mas a própria orientação do ensino [...]", proposta aceita apesar de afrontar a tradição centenária da escola. A iniciativa, naturalmente encontrou forte resistência interna e acabou frustrada pela curta permanência de Lucio Costa na direção assumida (1984, p.109). Ainda assim, a partir dessa breve experiência foi possível preparar "o grupo de arquitetos cariocas que tão grande desempenho veio a ter na 'descoberta' da Moderna arquitetura Brasileira" (SINOPSES, 1993, p.149).

Tendo como referência essa proposta de Lucio Costa, a pequena mas já relativamente organizada categoria conseguiu criar nas décadas seguintes, os primeiros dos seus imprescindíveis cursos autônomos de arquitetura, desvinculados das escolas de belas artes e de engenharia onde eram ministrados.

Entretanto, a existência desses novos cursos, viabilizada a partir da década de quarenta, não conseguiu resolver a contradição entre o projeto que levou a criá-los e o peso das tradições das duas escolas matrizes da formação dos arquitetos brasileiros: a das "belas artes" e a das "politécnicas", numa época em que a Escola Nacional de Belas Artes do Rio de Janeiro e a Escola Politécnica de São Paulo, estendiam sobre todo o País suas raízes fincadas na Paris do século XVIII.

Se as reformas então iniciadas tinham consciência dessa contradição e procuraram superá-la, o fato é que ela continua marcando profundamente a arquitetura como um fenômeno não só nacional, mas mundial, por exemplo, na ainda mal-resolvida relação entre arte e técnica, objeto de 
intermináveis debates tanto na vertente acadêmica quanto na prática profissional.

Além disso, até pela evidência dessa contradição, de caráter conteudístico, não foram consideradas questões de outra natureza que passaram a comprometer o projeto das novas escolas, e que Miguel Pereira identificou como "vícios", ao se referir à forma de organização, transmissão e produção do conhecimento.

"Oriundas da fusão de antigos cursos de Arquitetura das Escolas de Belas Artes com os cursos de Arquitetura das Escolas de Engenharia, as Faculdades de Arquitetura trouxeram consigo, de maneira mais acentuada, aqueles vícios de atomização dos setores de conhecimento que interessam à formação do profissional arquiteto: o projeto, a tecnologia e o conhecimento histórico-crítico. São os reflexos da Universidade clássica, arcaica e estiolada, onde os setores de conhecimento não se integram, mas se justapõem, ensaiando, no máximo, uma vizinhança admitida." (1984, p.110)

Dessa forma, ainda segundo Pereira, esses vícios teriam levado a que cada escola de arquitetura se comportasse "como verdadeiras universidades", nela isolando as disciplinas desses conhecimentos, que "perdem sua potencialidade de crescimento, pois esta se vincula à convivência e ao debate com seus pares e emana, igualmente, de seus laboratórios". Até porque a universidade brasileira não tinha uma estrutura acadêmica verdadeira ${ }^{3}$. Como conseqüência, essa "escola" produziu um "meio-arquiteto", um "arquiteto clínico-geral", de inatas e privilegiadas vocação e criatividade, guiado por um "modelo" de arquitetura centrada unicamente no edifício e, portanto, inapto para enfrentar a realidade profissional cada vez mais complexa (Idem, p.110-12).

Embora publicado pela primeira vez em 1973, o diagnóstico apresentado nesse artigo revelou com perspicácia e precisão não só a problemática conjuntural da época, mas principalmente o caráter estrutural da crise do

\footnotetext{
${ }^{3}$ Ver nota 7.
} 
ensino e da profissão de arquitetura no País, quadro que se mantém inclusive até os dias atuais, distante daquele pretendido por Lucio Costa em 1930.

Por essa razão e também pela própria suscetibilidade dessa e de qualquer profissão às inevitáveis transformações sociais, a história das escolas autônomas de arquitetura no país foi marcada desde o seu início por uma sucessão de tentativas de reformas. 


\subsection{Panorama das reformas}

Tão logo foram implantados, os novos cursos no Brasil passaram a exigir a solução dos inevitáveis problemas decorrentes dos "vícios" de origem, conforme foi caracterizado por Miguel Pereira. No caso da FAUUSP, o encaminhamento desses problemas se revelaram "uma de suas 'vivências' mais dramáticas” e a organização do ensino era desde a sua criação "assunto de preocupação constante das administrações, dos professores, dos estudantes, dos arquitetos já diplomados" (PRADO, f.2).

Esse processo, que se estendeu às outras escolas, pode ser ilustrado por um conjunto de casos emblemáticos representados pelas faculdades de arquitetura da Universidade de São Paulo (FAUUSP), da Universidade Federal do Rio Grande do Sul (FAUFRGS) e da Universidade de Brasília (UnB), criadas em 1948, 1952 e 1962, respectivamente, que considerados por Miguel Pereira como os três pólos referenciais das "mais significativas reformas de ensino, acontecidas no Brasil das últimas décadas" (2005, p.111).

Já nos anos seguintes à sua criação, a FAUUSP e a FAUFRGS conduziram ativamente as discussões sobre o ensino de arquitetura congregando alunos, professores e profissionais. Foram realizados diversos eventos sobre o tema, principalmente em São Paulo, Porto Alegre e Belo Horizonte, inclusive com a participação de diretores de faculdades nos últimos encontros ${ }^{4}$.

\footnotetext{
${ }^{4}$ Cintra Prado relaciona os eventos que promoveram o movimento pela reforma do ensino no fim da década de cinqüenta e no início dos anos sessenta. Os de caráter mais abrangente seriam "os Congressos Nacionais ou Brasileiros de Arquitetos, incluindo em seus temários, o ensino de Arquitetura e suas relações com a profissão. O I ${ }^{\circ}$ foi em São Paulo (1945); o II em Porto Alegre (1948); o III ${ }^{\circ}$ em Blo Horizonte (1953); o IVº em São Paulo (1954)". Com temário específico, foram realizados os "Encontros de Estudantes e Arquitetos" "(O ${ }^{\circ}$ em São Paulo, outubro-1958, como prolongamento do "Primeiro Seminário do Ensino da
} 
Em São Paulo, ainda segundo Miguel Pereira (1984, p.83; 2005, p.110111) a proposta de reforma em elaboração pela FAUUSP procurava responder às questões mais candentes da discussão nacional e os seus conceitos já se achavam consubstanciados no projeto do futuro edifício da Cidade Universitária, de autoria de Vilanova Artigas: o ateliê, o departamento e o museu, este último como instância de síntese dos das disciplinas práticas e teóricas. O projeto didático elaborado para subsidiar o partido da nova sede da escola já previa a criação das "cinco famosas seqüências para a formação do arquiteto: Edificação, Planejamento Urbano, Paisagismo, Comunicação Visual e Desenho Industrial".

Essa reforma da FAUUSP foi implantada em 1962, mesmo ano da reformulação do curso de arquitetura da FAUFRGS conforme proposto pelo chamado Plano de Emergência de $1957^{5}$.

O ano de 1962 foi marcado também pela criação da Universidade de Brasília, que revolucionaria a própria estrutura universitária e "com ela, os caminhos da própria formação profissional dos arquitetos" (PEREIRA 2005, p.112). O primeiro curso a ser implantado foi o da Faculdade de Arquitetura e Urbanismo, com um ensino "amplo e flexível, em nível de

\footnotetext{
Arquitetura e Urbanismo'; o $I^{\circ}$ em Porto Alegre, abril-1960). Seguiram-se os 'Enconctros' entre Diretores, Professores e Alunos (O $1^{\circ} \mathrm{em}$ Belo Horizonte, agosto-1960; o II em Salvador da Bahia, julho-1961; o III em São Paulo, julho1962). Esses dois gêneros de 'Encontros' foram unificados em 1962." No ano de 1963, "realizou-se na FAU o 'Primeiro Fórum de Debates', o qual tratou, entre outros temas, do ensino de Arquitetura. Desses certames [resultaram] recomendações, resoluções e proposições ... marcos na evolução do pensamento dominante" que refletiam "as conjunturas das respectivas datas." (p.3). Eventos com enfoque na reforma universitária também eram realizados à época: o seminário de Reforma de Ensino, sob o patrocínio da UNE, Rio de Janeiro, 1957; I Seminário Latino-americano de Reforma e Democratização do Ensino Superior, Salvador, 1960; I Seminário Nacional de Reforma Universitária, Salvador, 1961. (PEREIRA, 1984, P.148)

${ }^{5}$ Para Miguel Pereira, as características desta reforma eram: divisão do curso em dois ciclos, o Básico (4 primeiros semestres) e o Profissional (6 últimos semestres), com carga decrescente do conteúdo técnico e crescente do conteúdo projetual (arquitetura e urbanismo) ao longo do curso ("visão do famoso retângulo, cuja diagonal traduzia o divisor de águas do tal procedimento" (1984, p.109); inaugurou também o sistema semestral no ensino de arquitetura.
} 
graduação e pós-graduação" que se relacionaria abertamente "com todas as áreas de conhecimento, principalmente, através das artes Plásticas". Além de se organizar através dos elementos estruturais da nova Universidade: Ciclo Básico, Ciclo Profissional, Regime Didático Semestral, Congregação de Carreira, o curso "inovava a relação de seus professores com a prática profissional e com a administração" por meio do CEPLAN (Centro de Planejamento), composto de seus professores, com o duplo objetivo de "elaborar todos os projetos do Campus e servir de base à pesquisa, [esta] provinda do Atelier, relacionada aos programas didáticos" (PEREIRA, 2005, p.110-111). A formação do arquiteto previa dois níveis: o primeiro era universitário e era cumprido no ICA - Instituto Central de Artes, "ponte pela qual o ensino de arquitetura se relacionava com a universidade"; o segundo, profissional, na Faculdade de Arquitetura e Urbanismo (ALMEIDA, p.101-102). Todavia, o projeto original tanto do curso de arquitetura como da própria universidade teve uma duração de apenas três anos, abortado que foi pelo fechamento desta decretado pelo governo militar em 1967 (PEREIRA, 2005, P.111).

Da mesma maneira que na Universidade de Brasília, os projetos de reformulação das duas outras escolas aqui consideradas, FAUUSP e FAUFRGS, foram descaracterizadas pelo fechamento político promovido pelo regime militar e pela Reforma Universitária de 1968.

Mesmo assim, essas propostas pioneiras permaneceram como conquistas possíveis e significativas para a construção da autonomia do ensino de arquitetura e constituíram inquestionável referência para a reconceituação de outros cursos existentes ou para a conceituação dos outros, criados posteriormente. Por outro lado, elas mesmas se mantiveram como matrizes para as sucessivas revisões, num processo que se estende aos dias atuais, apesar da pela drástica mudança de contexto imposta pelo governo militar.

A FAUUSP, por exemplo, teve neutralizadas as propostas aprovadas no seu $2^{\circ}$ Fórum, realizado às vésperas da implantação da Reforma 
Universitária com o objetivo de avaliar e revisar a reforma de 1962.

Na FAUFRGS, como de resto em todas as escolas de arquitetura e na universidade brasileira no seu conjunto, a Reforma Universitária "organizou os Cursos não mais por Faculdades ou Escolas, mas por conjuntos de disciplinas a serem ministradas por diferentes Departamentos", desarticulando o corpo docente dispersados pelos diferentes departamentos e comprometendo a integração dos conhecimentos por parte dos alunos. Os primeiros anos após a implantação da Reforma, como era de se esperar, foram marcados pela "falta de participação e de convívio universitário" em razão do "desaparecimento do conceito de turma, os horários diversificados, a falta de integração entre professores e alunos”. Esses problemas, somados á franca opção política de "metas desenvolvimentistas materiais, contribuiu(iram) para a consolidação do esfacelamento do chamado espírito universitário" (SILVEIRA, p.4).

Na Universidade de Brasília, os cursos do Instituo Central de Artes e da Faculdade de Arquitetura e Urbanismo foram reestruturados e retomaram as atividades regularmente em 1968. Com a "implantação da estrutura da Universidade de Brasília, através da aprovação de seu Estatuto", o ICA e a FAU se fundiram e deu lugar ao Instituto de Artes e Arquitetura, o "IA" (ALMEIDA, p.110).

A experiência a registrar nesse período, afora os exemplos dessas três escolas, por sinal públicas, foi a da Faculdade de Arquitetura e Urbanismo de São José dos Campos, mantida por uma entidade privada no Estado de São Paulo. Com base na análise crítica dos "modelos" de ensino de arquitetura até então praticados e após algumas experiências mal sucedidas foi desenvolvido e implantado o chamado sistema de Unidades Interdepartamentais de Ensino e Pesquisa - UID - que eram espaços integradores das atividades de "investigação-pesquisa-prática" e voltadas para temas de interesse social e acadêmico. As UID eram distribuídas ao longo de oito semestres intermediários do curso organizado em dois 
ciclos e os alunos podiam optar entre uma dezena de temas oferecidos. A mantenedora não concordava com a proposta que implicava a redução tanto do seu pretendido "poder absoluto" quanto das "suas expectativas de lucro" e "suspende" as atividades da escola em 1976, dando fim à experiência iniciada em 1970 (FERNANDES et alii, p.129-133).

A pesada repressão política, autorizada por instrumentos legais como o Decreto 477 e do próprio Ato Institucional n 5 , o Al-5, do Regime Militar ${ }^{6}$ durante a primeira metade dos anos setenta, impediu as escolas de arquitetura a proceder à devida avaliação dos efeitos da implantação da Reforma Universitária. A reorganização de seus cursos só foi retomada após os primeiros movimentos da sociedade em prol da redemocratização. No campo da arquitetura, profissionais e estudantes, reunidos no IX Congresso Brasileiro de Arquitetos em São Paulo em 1976, se posicionaram firmemente pela redemocratização e pela retomada das discussões sobre a formação profissional, abrindo caminho para as necessárias revisões represadas ao longo dos anos da repressão mais intensa.

Assim, não foi coincidência que a FAUUSP tenha realizado o último dos grandes fóruns em 1978 e a FAUFRGS os seus Seminários de Ensino em 1978 e 1979 que resultariam nas modificações curriculares introduzidas a partir de 1982 (SILVEIRA, p.2).

Desse modo, a partir do fim da década de setenta se generalizaram as ações visando a reformulação do ensino nas escolas de arquitetura, mas as propostas passaram a se centrar mais na questão do ensino de projeto. As discussões se voltaram mais para os aspectos operacionais do ensino e essa postura técnica e administrativa contrastavam claramente com o forte posicionamento político dos movimentos que precederam a decretação da Reforma Universitária. Pode-se dizer que,

\footnotetext{
6 “[...] o Ato Institucional n5/68 e o Decreto-lei 477/69 ameaçavam com a perda ou a limitação de emprego futuro os professores, e com a expulsão os estudantes que fossem acusados e culpabilizados, em rito sumário, por prática de atividades consideradas subversivas." (CUNHA, In: LOPES, FARIA e VEIGA, p.178)
} 
nesse sentido, após apenas uma década de vigência, a Reforma Universitária cumpriu seus objetivos e expandia seus resultados.

Vencida a fase de retomada das discussões sobre o ensino, a UFRGS realizou, em 1985, o "I Encontro sobre Ensino de Projeto Arquitetônico", considerando que a melhoria da formação do arquiteto envolvia principalmente a reforma do ensino de projeto como atividade distintiva do fazer arquitetural.

Por sua vez, a FAUUSP realizou um seminário geral em 1986 com vistas a reestruturação de todo o curso. Se os resultados desse evento foram pouco significativos, as discussões e as poucas propostas aprovadas apontavam para o Departamento de Projeto como espaço que abrigava os maiores problemas para o ensino do curso como um todo. Após um período de relativa inércia, o Departamento iniciou um longo processo de discussão interna em 1992 que culminou com a reestruturação implantada em 1998. Por sua vez, face aos problemas que foram identificados na nova estrutura, o mesmo Departamento desencadeou novo processo de discussão interna, iniciado em 2005 e ainda em curso.

Já na Universidade de Brasília, o fórum de 1989 separou as áreas das artes e da arquitetura criando a FAU/UnB e o Instituto de Artes (IdA), desarticulando as atividades de ensino, pesquisa e extensão. Em 1996 se procedeu a uma reorganização que "extinguiu os departamentos de Arquitetura e Urbanismo, criando os novos departamentos de a) Projeto, Expressão e Representação da Arquitetura e Urbanismo; b) Teoria e História da Arquitetura e do Urbanismo; e c) Tecnologia da Arquitetura e do Urbanismo" (BARRETO, p.63). 


\section{$1.2 \quad$ Fases e modelos}

Nessa curta história do ensino autônomo de arquitetura, iniciativas semelhantes às da USP, UFRGS e UnB - caracterizadas por Miguel Pereira como as mais significativas (2005, p.111), - se sucederam no âmbito das outras faculdades e universidades do país, públicas, confessionais ou privadas, resultando em propostas implantadas ou que não saíram do papel.

Entretanto, ainda hoje se continua a detectar problemas, novos e antigos, que comprometem a quase totalidade das experiências: muitas foram consideradas insatisfatórias; poucas consideradas promissoras foram inviabilizadas por razões não acadêmicas, como aquela original de Brasília e a de São José dos Campos, para citar as mais lembradas. A primeira por notórias razões político-ideológicas e a outra por interesses imediatistas de uma instituição empresarial privada. Há notícias de outros projetos considerados promissores que igualmente foram frustrados por interferência das mantenedoras e que merecem estudo mais aprofundado: Santos, Taubaté, Mogi das Cruzes, para citar de memórias casos próximos no Estado de São Paulo.

Dessa forma, ressalvados os casos citados, a provável explicação da pouca eficácia das tentativas de melhoria do ensino de arquitetura brasileiro não pode ser buscada nos fatores externos ao processo do ensino propriamente dito. Se for considerado que, em geral, as propostas foram formuladas com absoluta coerência e consistência, a análise da sua fundamentação pode contribuir para a explicação desse quadro do impasse que se configurou.

Nesse sentido, cobra importância o exame do documento referente à experiência da FAU São José dos Campos, na medida em que não só 
relata com detalhes mas analisa criticamente todo o processo daquela experiência. Nesse trabalho, redigido por um grupo de ex-professores e alunos da escola, apresentado no IX Congresso Brasileiro de Arquitetos realizado em São Paulo no ano de 1976 (IX CONGRESSO, p.125) ${ }^{7}$, é de interesse específico para o presente trabalho, a caracterização das quatro "fases principais" e dos cinco "modelos" de ensino ao longo da história recente do ensino de arquitetura no país.

\subsubsection{As fases de desenvolvimento do ensino de arquitetura}

Segundo o documento, numa primeira fase, a das escolas autônomas e que foi denominada a dos "Cursos seriados", o ensino se organiza pela "justaposição de disciplinas técnicas e artísticas". Ao mesmo tempo, vai se consolidando a percepção da necessidade dos arquitetos de preparar melhor e mais quadros tanto para a afirmação profissional quanto para atender organizadamente a demanda de um mercado de trabalho em crescimento, então disputado com os engenheiros civis. Tem início, assim, o processo de institucionalização do ensino de arquitetura.

A segunda fase seria de "de afirmação profissional", tanto respaldada pela conquista de formação profissional independente quanto favorecida pela notoriedade que ganha a arquitetura no processo das grandes transformações ocorridas no País na década de 50, principalmente com a construção do Parque Ibirapuera e o concurso do Plano Piloto de Brasília. O próprio projeto passa a ser valorizado como instrumento da ação transformadora. Nesse panorama, se organizam intensos movimentos de afirmação da profissão.

Assim,

\footnotetext{
${ }^{7}$ Também publicado em Lima et alii, in LIMA, p.63-70.
} 
"No começo da década de 60 , os cursos de arquitetura sofrem modificações no sentido de melhor atender ao papel de formar profissionais capacitados. Ao mesmo tempo, a universidade brasileira atravessa um período de discussões profundas sobre seu papel histórico, seu compromisso com uma realidade nacional em transformação. Esta fase é marcada, nos cursos de arquitetura, por uma postura muito mais voltada às perspectivas do campo profissional, do que às proposições transformadoras da Universidade." (Idem p.126)

Na fase seguinte, a de "expectativa de 1966/69", a universidade passa a resistir a pressões do Governo Militar recém implantado, "chegando a constituir-se no principal pólo de critica e inconformismo perante a situação" (idem, p.126).

"As alterações nos cursos de arquitetura passam a ser determinadas pelo próprio meio universitário, que exigia uma reforma mais ampla e radical da instituição. Os cursos de arquitetura buscam uma resposta política a um projeto de Universidade Nacional, e ao mesmo tempo, a retomada das posições pregadas na fase anterior." (Idem, p.126)

A partir de 1969 caracteriza-se uma nova fase com a implantação unilateral da reforma universitária pelo Governo para buscar "moldar os cursos de acordo com as necessidades imediatas e objetivos da produção capitalista", e que resulta em

“[...] aumento de vagas pela abertura indiscriminada de novos cursos; daí o aumento da rede privada e do ensino pago; orientação pragmática dos cursos; redução dos gastos em pesquisa e aperfeiçoamento; ênfase em aspectos quantitativos. [...] Os cursos de arquitetura são reduzidos geralmente na prática a cursos seriados, devido ao corte de recursos financeiros destinados ao ensino superior, em todas as escolas do pais." (Idem, p.126).

Observe-se que a análise desenvolvida pelo documento alinha-se, na essência, com aquela de Miguel Pereira em termos do diagnóstico da tendência de empresariamento que passou a marcar o ensino superior em geral e, em especial, o ensino de arquitetura no Brasil não só nos 
meados da década de setenta mas que ganhou nova força nos dias de hoje com a globalização da economia. 


\subsection{Os modelos de ensino}

No documento mencionado são configurados cinco modelos de ensino em função dos seguintes parâmetros: "1. forma regimental; 2 . organização funcional e operativa - órgãos, conselhos, departamentos, etc.; 3. Estrutura curricular -distribuição de cargas horárias e conteúdos; 4. Conteúdo programático e metodológico." (FERNANDES et alii, p.127)

Os primeiros cursos independentes de arquitetura se organizavam pelo modelo de "cursos seriados", justapondo disciplinas técnicas e artísticas das duas tradições do ensino da profissão, politécnicas por um lado e belas artes e liceus do outro. (FERNANDES et alii, p.126). Esse modelo dos primeiros cursos foi reproduzido pelas escolas criadas após a Reforma de 1968.

"Mesmo formalmente distribuídas em departamentos - exigência da própria legislação da Reforma do Ensino Superior - as disciplinas nos cursos seriados são autônomas, estanques e isoladas entre si. Cada professor programa sua disciplina desconhecendo na maioria das vezes, os programas dos demais mesmo aquelas mais correlacionadas a sua, de seu próprio Departamento. Atende-se ao pé da letra o estabelecido pelos currículos mínimos oficiais, geralmente copiando-se programas análogos de cursos existentes, resultando em estruturas operacionais de baixo custo de manutenção. As relações das disciplinas não vão além dos 'pré-requisitos', colocando-se como condição de matrícula nas disciplinas de uma determinada série, o cumprimento anterior e a aprovação nas disciplinas da série anterior". (Ibidem, p.127).

Um outro modelo seria o de "ateliê central": parte do esforço de afirmação profissional das primeiras décadas, resulta da busca de um espaço didático-pedagógico e político compatível com as novas responsabilidades e direitos que então estavam sendo conquistados pela profissão em franca ascensão. 
"Toma corpo o Departamento de Projeto, com grande maioria de professores arquitetos que organizam um novo espaço escolar: o Ateliê [... cuja] estrutura admite 'linhas de trabalho', as quais seriam combinadas horizontal e verticalmente $[\ldots]$

Na prática, as demais disciplinas dos outros Departamentos das escolas de Arquitetura, permanecem isoladas em sua seriação inicial. O Ateliê torna-se um veículo de afirmação dos arquitetos no sentido de melhor controlar o processo de ensino" (Ibidem, p.127).

Esta proposta foi implementada pioneiramente na FAUUSP, como resultado de intensa mobilização das partes interessadas, professores, alunos e profissionais. Lembram os autores que a proposta inicial do ateliê era mais ambiciosa, na medida em que pretendia integrar

"[...] todas as disciplinas que compõem o curso de arquitetura, em torno do 'eixo central" da escola, o Ateliê " (Ibidem, p.127).

O modelo de "ateliê central" teria sido a adequação e redução da proposta inicial mais abrangente ao "nível do possível, nessa época".

A viabilização da proposta original configurou o modelo que foi denominado "ateliê interdepartamental" ou "ateliê integrado", ou "A.I.", a partir dos debates suscitados pela reforma universitária de 1968. A proposta básica dos A.I. são:

“- o ateliê como espinha dorsal do curso de arquitetura;

- as disciplinas técnicas e históricas comparecendo ao ateliê informando e assessorando a elaboração dos projetos, e subordinadas à temática e à programação daquele Departamento;

- o Projeto, como atividade meio e fim do curso, seu produto final;

- os temas de Projeto (que permitam a integração das linhas em horizontal e vertical) escolhidos a partir de um repertório das atividades profissionais exercidas pelos arquitetos." (Ibidem, p.128) 
Um modelo que seria "tipicamente universitário", o Instituto de Arte se organiza em dois ciclos que permitem articular a formação mais abrangente e a formação mais específica. No primeiro ciclo, em muitos casos de dois anos, "são agrupadas as disciplinas de diversos cursos" para uma formação básica comum; o segundo ciclo "é orientado para a formação profissional" específica.. O modelo foi proposto pela Universidade de Brasília e pretendeu "uma ampliação do horizonte de conhecimento dos estudantes - no ciclo básico - pelo contato com outras áreas afetas à arquitetura, comunicações e artes em geral", para melhor situar a especificidade a ser trabalhada no outro ciclo.

A partir de criticas aos modelos anteriores surgiu o modelo das "Unidades Interdepartamentais de Ensino e Pesquisa", as UID.

Esta proposta foi apresentada na época do documento (1976) como "a forma mais recente de curso de Arquitetura e Urbanismo posto em prática no pais" (Ibidem, p.128), mas cuja estrutura operacional tenta conciliar "os mecanismos dos modelos anteriores e a nova legislação do ensino superior brasileiro". Entre seus objetivos constam a "integração docênciapesquisa", "participação direta e ativa" dos estudantes no ensino, a viabilização da pesquisa pelos docentes, "troca de experiência e contato entre a população local e a população escolar" (Ibidem, p.131).

Uma característica distintiva das UIDs é que não estabelecem um "modelo acabado de profissional a ser formado" e valorizam a formação do aluno a crítica do aluno e não apenas o aprendizado para sua "atuação profissional futura - após a conclusão do curso." (Ibidem, p.131)

Mantêm-se, nesse modelo, o sistema de promoção por créditos e os dois ciclos dos institutos de artes mas não há pré-requisitos dentro de cada ciclo e os alunos podem optar pelas UID oferecidas nos dois ciclos (no mínimo 3 no primeiro e 5 no segundo) e os alunos se inscrevem de acordo com a seqüência semestral que julgarem mais conveniente. $O$ 
trabalho de graduação (TG, TGI, TFG, TC) deve estar vinculado a uma dessas UID (Ibidem, p.128).

A par dessa sistematização desses modelos, será oportuno lembrar que algumas experiências no exterior parecem ter subsidia do e alimentado a dinâmica desse processo de revisão do ensino de arquitetura no Brasil (Pereira, 2005, p.82-3). Mereceriam estudo mais aprofundado o conhecido "taller total" de Córdoba, Argentina, nos anos 70, cujo modelo a UNB tentou repetir depois de 1967; a "Escuelita", que não se colocava como uma escola clássica: "não há diplomas, é uma escola que ensina arquitetos e estudantes, não tem curso regular, semestral ou seriado. São conferencistas, professores, visitantes e professores argentinos e estrangeiros que se organizam em torno de cursos, com determinados princípios básicos" (Ibidem, p.83). Desde 1956, a Argentina tem oferecido o exemplo do "ateliê vertical", modelo de ensino de projeto implantado na Faculdade de Buenos Aires e que rapidamente, mas não sem criticas, foi adotado pela maioria das escolas argentinas (CORONA MARTINEZ, p. 86).

Experiência mais recente e digna de nota é a da Escola da Cidade, funcionando desde 2002 em São Paulo com projeto de ensino que incorpora e consolida um conjunto de propostas anteriores, inovadoras mas inviabilizadas na prática. Um aspecto distintivo da escola é o fato de ser mantida por uma associação de professores que conseguem assegurar sua auto-suficiência, isto é sua independência econômicofinanceira, condição sine-qua-non para a necessária autonomia pedagógico-didática de uma verdadeira instituição universitária. Formando a sua primeira turma no corrente ano, ainda é uma experiência a ser avaliada, mas que desde já demonstra a viabilidade de outros caminhos nessa situação de impasse do ensino de arquitetura no país.

${ }^{8}$ Ver também DÍAZ et alii. 
A tipificação dessas cinco formas de organização de cursos de arquitetura ainda pode ser considerada válida, mesmo passadas três décadas de sua formulação, no sentido de que as propostas surgidas posteriormente basicamente reproduzem-nas ou delas constituem variantes.

Nessa sistematização e no breve histórico anteriormente apresentado se delineiam algumas peculiaridades do ensino de arquitetura que merecem maior aprofundamento para efeito deste trabalho. Uma característica própria da organização do ensino de arquitetura em suas diversas fases e formas de ensino é a necessidade de um espaço específico, não só didático mas também físico, consagrado historicamente como "ateliê". Com efeito, já no modelo dos "cursos seriados" algumas disciplinas eram desenvolvidas nos ateliês herdados das suas matrizes, as escolas das "belas artes" e das "politécnicas". Na fase subseqüente, ou "fase de afirmação profissional", o ateliê passa a assumir um papel central na organização do ensino de arquitetura e essa concepção de ateliê é mantida nas propostas posteriores dos "ateliês integrados" e do "instituto central de artes" e mesmo a das "uids".

O ateliê é um espaço por excelência de exercitação da habilidade de projetar, exigidas pelo caráter prático, ou "aplicativo" da profissão de arquitetura $^{9}$. Na medida em que essa atividade é central ao fazer profissional, o ateliê ganha força na organização do ensino de arquitetura como profissão e como objeto de estudo. Não é sem razão que o ateliê, na sua forma moderna, é implantado como resultado do vigoroso movimento pela valorização do projeto e da profissão sustentado na década de cinqüenta e se torna modelo padrão do ensino de arquitetura, como, aliás, confirma Katakura:

\footnotetext{
${ }^{9}$ Para Barreto, arquitetura é uma "disciplina de aplicação" e, como tal, integra os conhecimentos necessários para a concepção da forma a ser construída (p.64).
} 
"Quase toda a educação arquitetônica está baseada no trabalho do projeto, boa parte das escolas tem como eixo principal a formação do arquiteto para a prática do projeto de arquitetura e urbanismo. Entretanto, as escolas adotam diferentes meios para resolver as relações entre o conhecimento básico teórico e as habilidades apreendidas por meio da experiência do projeto" (p.32). Uma outra peculiaridade que pode ser observada, ainda que de forma implícita, é a lógica subjacente na organização do ensino que busca um procedimento "co-laborativo" considerado fundamental no processo de aprendizado de uma profissão de caráter prático.

Essa preocupação se revela na valorização das propostas de “integração", por um lado, das atividades organizadas pelas disciplinas e departamentos, com ênfase naquelas "de ateliê" e, por outro, das chamadas "atividades acadêmicas" - o ensino, a pesquisa e a extensão.

Propõe-se, para o primeiro caso a inter e a multidisciplinalidade quando não a interdepartamentalidade, o que, em última análise, constitui o anseio por um aprendizado conjunto; no segundo caso, o contato com a realidade exterior para romper o isolamento da academia, para superar 0 tão questionado descompasso do ensino em relação à prática de arquitetura. Fica aí, subjacente, o entendimento de que toda atividade prática tem como inerente a integração das atividades de apropriação e a produção de conhecimentos, além da solução de um problema da sociedade - correlatos profissionais daquelas atividades acadêmicas fundamentais. 
2 As reformas da FAUUSP 
A postura crítica com relação ao ensino caracterizou a FAUUSP desde a sua criação e constituiu a fonte e o motor do processo ininterrupto de seu questionamento e reformulação. Já observava o Professor Luiz Cintra do Prado na aula inaugural da FAUUSP em 1964:

"Os problemas do ensino da Arquitetura têm sido, desde a fundação desta casa, em 1948, uma de suas 'vivências' mais dramáticas: a organização do ensino foi, e continua a ser, assunto de preocupação constante das administrações, dos professores, dos estudantes, dos arquitetos já diplomados" (p.2).

Com efeito, desde o momento da implantação do curso, seu currículo foi alvo de criticas por ser considerado apenas "somatória de disciplinas" e incompatível com o modelo de arquiteto pretendido (ARTIGAS, p.134). O movimento por sua alteração teve êxito em 1955, inaugurando as reformas que se sucederiam ao longo da história da escola ${ }^{10}$.

Dentre as mais significativas experiências desse processo a mais importante foi a de 1962. De fato, a chamada "Reforma de 62" teve um papel decisivo não só para a FAUUSP, mas para o próprio ensino de arquitetura do pais, uma vez que se tornou referência para as reformulações da maioria das demais escolas brasileiras. Foi a primeira reforma de fato da FAUUSP e uma das três grandes implantadas naquele ano, ao lado da UFRGS e UnB, foi a que conseguiu articular e viabilizar

10 Em 1948, foi extinto o curso de engenheiro arquiteto da Escola Politécnica e criado o de arquiteto da FAUUSP. Apesar do currículo da nova escola ter também resultado de uma "fusão" de conteúdos da Escola de Belas Artes de Rio de Janeiro e da Escola Politécnica de São Paulo, observa Marlene Yurgel que "em 48, por ocasião da criação da FAUUSP, há uma afinidade marcante no curriculum com o curso da Escola do Rio, em 55 o curriculum se modifica, retornando à identidade com o programa de carreira de engenheiro arquiteto da Politécnica" (p.125) 
com eficácia o conteúdo das inúmeras propostas geradas pela intensa campanha desencadeada nos anos 50 na luta pela autonomia do ensino de arquitetura e pela conquista de uma legislação profissional à altura do prestígio e da importância que havia alcançado a arquitetura brasileira ${ }^{11}$. Por outro lado, fator importante para a disseminação dessa organização curricular talvez tenha sido o fato de a FAUUSP tê-la concebido e implantado dentro de uma estrutura "mais conservadora" na qual era necessário "romper barreiras", à semelhança do que acontecia com as demais escolas (PEREIRA 2005, p.112-113). Não havia, na USP nem na UFRGS, a possibilidade de ignorar esses obstáculos ou pensar um ensino inteiramente novo como acontecia com o nascente curso da UnB, organizado dentro de uma estrutura acadêmica inovadora.

Devido à semelhança das estruturas dentro das quais funcionavam, a grande maioria das escolas de arquitetura brasileiras adotaram "totalmente ou em parte" a nova organização curricular. Por outro lado, cabe observar que as reformulações realizadas por essas escolas não constituíram simples reprodução dessa proposta e que alterações e adaptações necessárias em cada caso acabou por gerar uma tendência de "diversificação um tanto caótica dos "currículos e programas" - em razão de uma provável falta de "orientação básica capaz de unir todas as escolas para um mesmo objetivo" como supõe Artigas (1993, p.136). Desse modo, ganha importância a tentativa de resgate da conceituação e do funcionamento originais da proposta, em particular em relação ao modelo de ensino fundado no ateliê, referencial fundamental na análise das reformas posteriores.

${ }^{11}$ Segundo Cintra Prado as principais manifestações dessa campanha foram: Congresso Nacional ou Brasileiro de Arquitetos, que incluía em seus temários o "ensino de Arquitetura e suas relações com a profissão: "l" em São Paulo (1945), "II" em Porto Alegre (1948), "III" em Belo Horizonte (1953), "IV" em São Paulo (1954); Encontro Nacional de Estudantes e Arquitetos: “I” em São Paulo (1958, outubro) "como prolongamento do 'Primeiro Seminário do Ensino da Arquitetura e Urbanismo"', "Il" em Porto Alegre, (1960, abril); Encontro entre Diretores, Professores e Alunos: "I" em Belo Horizonte (1960, agosto), "II" em Salvador (1961, julho), "III" em São Paulo (1962, julho-1962). Esses dois encontros foram unificados em 1962. No Encontro Regional de Educadores Brasileiros em São Paulo (1960), "uma comissão de arquitetos, ligados à FAU, recebeu a incumbência de analisar o ensino da Arquitetura em nosso pais". (p.3) 


\subsection{O ateliê como estratégia}

A reforma implantada na FAUUSP em 1962 tinha o ateliê centralizado "como linha mestra e ponto de síntese de todos os conhecimentos transmitidos" (PEREIRA, p.113), quatro anos após ser proposto formalmente pela chamada "reforma de 1957".

Prevalecia até então o sistema de cátedras isoladas que "gerou um ensino atomizante, de alto padrão teórico mas exclusivamente analítico, sem a indispensável integração dos conhecimentos recebidos através da aplicação prática" (CEZAR, p.12). Cada cátedra ${ }^{12}$, cadeiras ou disciplinas, tinha "planos independentes de trabalho escolar, o que sempre dificulta[va] a interpenetração efetiva dos conhecimentos, faltava, outrossim o modo eficiente de realizar a sua integração, no estudo dos projetos de Arquitetura" (PRADO, p.5).

Além disso, o curso da FAUUSP foi organizado através da adaptação do currículo padrão de arquitetura da Escola Nacional de Belas Artes, "com suas disciplinas de plástica, modelagem, arquitetura de interiores, grandes e pequenas composições" e, ao mesmo tempo, conservando o "programa de ensino técnico" característico da Escola Politécnica (ARTIGAS, p.134).

As cadeiras técnicas "são habitualmente regidas por engenheiros" e as artísticas "são dadas por artistas plásticos" ${ }^{13}$ porque quase todo o corpo docente do novo curso teve origem naquelas escolas, e não se percebe

\footnotetext{
12 Para Darcy Ribeiro, cada professor catedrático se isolava "em seu pequeno e, na maioria das vezes, decorativo laboratório, alguns deles dando aulas para dois ou três alunos". Além de outros problemas menos graves os catedráticos seriam a origem do "baixo nível do ensino e a falta de estímulo na formação de novos quadros de ensino e de investigação que se encontram[vam] impedidos de progredir ante a [sua] autoridade onipotente" (p.289).

${ }^{13}$ Faggin inclui entre os professores da área de artes os historiadores (p.131).
} 
que existe a necessidade de uma formação específica do arquiteto agora inserido em um novo contexto profissional (CEZAR, p.15). Tratava-se de uma fusão "imperfeita" de "dois domínios ... que permanecem paralelos, quase estanques"14 (PRADO, p.4).

Portanto, a reconceituação e a valorização do ateliê como instância estruturadora e integradora do ensino de arquitetura aparecia como a mais importante estratégia para uma radical transformação do ensino de arquitetura frente as exigências do novo contexto social e profissional.

Dentro da perspectiva acima, vale a pena chamar a atenção para o fato de que a "Reforma de 1962" foi a culminação de um longo processo interno, iniciado de forma mais conseqüente com a reforma curricular proposta em 1957.

\footnotetext{
${ }^{14}$ As escolas das belas artes e as das politécnicas criaram duas tradições de "tendências claras e antagônicas": o "formalismo acadêmico" daquelas e a "supervalorização da técnica, típicas da concepção positivistas do século XIX' destas (CEZAR, p.12).
} 


\section{$2.2 \quad$ A reforma de 1957}

A FAUUSP designou, em 1957, uma comissão de professores ${ }^{15}$ para "definir as grandes linhas da reforma que o momento parecia propiciar". A proposta central dessa comissão foi a valorização do ateliê como principal instrumento para os objetivos estabelecidos, na medida em que the parecia "acertado [... colcocá-lo] em posição de destaque e fazer convergir para ele todas as disciplinas do currículo" (PRADO, p.5).

A Comissão parte da constatação de que há um "sério desajuste entre os 'curricula' universitários e a vida profissional do arquiteto'”, cujas raízes devem ser buscadas menos no "processo de instruir os profissionais" e mais "dentro da própria organização da sociedade e nos conflitos entre a técnica e a arte contemporânea".

Era necessário, portanto, criar "métodos mais consentâneos com o nosso desenvolvimento" e "iniciar um novo ciclo de experiências em torno do ensino"16 , pois se reconhecia que "a 'Composição de Arquitetura' não estava tendo toda a importância devida - [...] como espinha dorsal na seriação das matérias - em correspondência natural com a importância que a mesma Composição tem [no] exercício da profissão do Arquiteto" (Ibidem, p.5).

Com esse propósito, a Comissão pretendia "consagrar o atelier como sede da mais importante tarefa na formação do futuro arquiteto, isto é, a realização da síntese ou 'visão unitária' de seus conhecimentos" disseminados em cadeiras ou disciplinas isoladas existentes na época,

\footnotetext{
${ }^{15}$ Arquitetos Abelardo de Souza, Helio Queiroz duarte, João Vilanova Artigas, Rino Levi (PRADO, p.5).

${ }^{16}$ Documento da Comissão (apud PRADO, p.5).
} 
razão pela qual que ficavam negligenciados "os aspectos humanos e sociais dos problemas da Arquitetura".

Nessa medida, o atelier haveria de ser o locus privilegiado do aprendizado e do domínio dos meios gráficos e plásticos para a expressão e representação e para a exercitação da "sua capacidade criadora, o que ele fará desenvolvendo a sensibilidade estética, ao mesmo tempo que irá cultivar a chamada 'mentalidade do construtor'. E, principalmente, [...] encontrar a ocasião de analisar, investigar, trabalhar no planejamento do meio físico e na organização dos espaços, 'em contato com exemplos vivos dos problemas reais da Arquitetura, a serem apresentados ali de forma muito próxima, senão idêntica, àquela com que tais problemas se encontram na prática da profissão"' (PRADO, p.5-6).

Na prática, entretanto, as alterações implantadas pela Comissão foram modestas. Se por um lado, havia unanimidade quanto à necessidade de uma reforma mais profunda (PRADO, P.6), por outro havia sérias dificuldades para implementá-la, provavelmente devido à legislação centralizadora de ensino em vigor, razão pela qual o que foi efetivado não passou de uma "modificação na seriação das cadeiras do currículo oficial" (Ibidem, p.17), concentrando as "cadeiras técnicas nos primeiros anos, práticas (composição) ao longo do curso [e] técnicas nos três anos centrais" (FAGGIN, p.131).

Apesar disso, para Cintra Prado, essas alterações indicaram o caminho para a integração dos estudos: "atendia-se expressamente à preocupação de convergência, de unificação, no aprendizado de conhecimentos extensos e diversos, tornando vivo o conceito de 'arquiteto integral', expressão ... insistentemente repetida ... nas escolas estrangeiras mais progressistas" (PRADO p.6).

Embora não tenha aprofundado o estudo do ateliê, a proposta de 1957 contribuiu para a sua viabilização futura ao reunir e organizar as cadeiras existentes, "estabelecendo distinções de natureza e de função educativa 
de cada matéria na formação do arquiteto" e criando "grupos de matérias de formação científica, de aplicação técnica, de cultura apropriada e do Ateliê" (MILLÁN, p.35). 


\subsection{As manifestações}

Algumas outras manifestações, sejam individuais sejam coletivas, pontuaram as reivindicações de arquitetos e estudantes pela criação de um espaço específico para a exercitação da habilidade de projetação.

Em outubro de 1958 foi realizado em São Paulo o I Seminário Nacional de Ensino de Arquitetura e Urbanismo que teve, como "prolongamento" (PRADO, p.3), o I Encontro de Estudantes e Arquitetos. Entre as contribuições dos estudantes, relativas ao ensino, acolhidas pelo Seminário figura a instituição do ateliê nas escolas, conforme consta das conclusões do encontro.

\section{"Quanto à composição ${ }^{17}$}

Considerada a importância do trabalho de criação e de objetivação dos conhecimentos adquiridos no curso, há necessidade premente de:

A - $\quad$ serem instituídos "ateliers" e o exercício efetivo de docências livres;

B - $\quad$ ser obtido o maior número de horas destinadas aos trabalhos de ateliers;

C - $\quad$ ser entendido este trabalho de ateliers como a linha mestra do ensino." (CEZAR, p.20)

O Segundo Encontro de Estudantes e Arquitetos (1960, abril) não se refere expressamente ao ateliê, mas aponta a necessidade de se criar uma legislação sobre o ensino superior "e "dotada de flexibilidade necessária para permitir a aplicação de formas de ensino condizentes com as exigências específicas" da profissão de arquitetura (CEZAR, p.27).

\footnotetext{
17 O termo "composição" era usado para designar o que hoje se conhece correntemente como "projeto": "Figuram assim, neste Departamento [de Projeto], as várias disciplinas de 'Composição de Arquitetura' (expressão que vai sendo substituída por outra, menos restrita, embora mais vaga, a de 'Projeto de Arquitetura')". (PRADO, p.9).
} 
Por sua vez, no I Encontro de Diretores, Professores e Alunos das Escolas e Faculdades de Arquitetura (1960, julho) recomendava que as "cadeiras de Composição" fossem estabelecidas como "eixo fundamental do curso" (FAUUSP-b, p.-). 


\subsection{Relatório "Roberto de Cerqueira Cezar"}

Em 1960 foi realizado em São Paulo, o Encontro Regional de Educadores Brasileiros. A comissão encarregada de analisar o ensino de arquitetura e urbanismo no país ${ }^{18}$ produziu um documento que consolidou objetivamente os diagnósticos produzidos até então sobre o assunto na "década de 50". O relatório, elaborado pelo professor e arquiteto Roberto de Cerqueira Cezar teve grande importância no sentido de melhor delinear o problema vivido pelo ensino de arquitetura brasileiro, condição fundamental para seu correto equacionamento.

O relatório reconhece a gravidade da situação do ensino de arquitetura e da profissão, mas conclui inserindo o problema na devida perspectiva histórica, na medida mesma das rápidas transformações e "evoluções" da sociedade e da profissão.

"São condições inteiramente novas que já se apresentam e que tendem a se acentuar para o futuro. É facilmente compreensível que a tal evolução deve corresponder uma reforma de base na concepção da própria formação profissional." (CEZAR, p.33).

Nessa medida, os problemas do presente não deveriam ser considerados deficiências do projeto que modelou o ensino:

"Assim, as falhas do atual ensino da arquitetura não são o resultado de insuficiências de organização tendo em vista o objetivo que se propunha alcançar na época em que foi concebida. É o resultado da vigência de condições e concepções inteiramente novas que é necessário satisfazer". (Ibidem, p.33).

\footnotetext{
${ }^{18}$ Essa comissão era composta pelos "professores arquitetos João Villanova Artigas, Roberto de Cerqueira Cezar, Hélio Duarte, Joaquim Guedes, Carlos Millán, Lúcio Grinover, Roberto Coelho Cardoso, Luiz Roberto Carvalho Franco, Rubens Maister, Miranda Maria Martinelli Magnoli" (MILLAN, p.6, grafia original)
} 
Como possibilidades de superação das novas condições que defasaram o projeto do ensino em vigência, Cerqueira Cezar relaciona uma série de proposições elaboradas pelos arquitetos e estudantes, algumas das quais praticadas correntemente "há bastante tempo" no exterior, inclusive nos paises sul-americanos. Em faculdades uruguaias e chilenas seriam "diretrizes assentes e normas habituais e já quase tradicionais":

'O ensino em 'Ateliers', com a integração das cadeiras técnicas no desenvolvimento dos trabalhos de projeto através de uma assistência efetivas dos professores dessas cadeiras; o contato contínuo com a planificação ampla em todo o curso de forma a criar no futuro arquiteto uma mentalidade urbanística real; a formação técnica concentrada na fase inicial do curso ..." (CEZAR p.31). 


\subsection{Comissão de Estudo do Ateliê}

A elaboração de uma proposta de criação do ateliê na FAUUSP foi o objetivo para a formação de uma "comissão restrita" de quatro docentes ${ }^{19}$ "incumbida por reunião ampla de professores da Faculdade a apresentar um primeiro estudo e uma estrutura preliminar para o Ateliê". O resultado dos trabalhos dessa comissão - "Comissão (ou Grupo) de Estudo do Ateliê" - foram publicados no início de 1962 (MILLÁN, p.5).

A proposta elaborada não foi implantada mas se colocava a "meio caminho entre o existente até então e o conteúdo da 'Reforma de 62'” e teve papel importante no processo de reformulação do ensino da faculdade.

Para a Comissão, o ateliê tinha como objetivos:

“1) realizar o aprendizado e domínio dos meios de representação e expressão gráficos;

2) iniciar o aluno, egresso dos cursos médios de caráter geral, no mundo dos valores plásticos e estéticos, desenvolvendo nele, pela experiência, a sensibilidade e a capacidade criadora, aliadas a uma necessária mentalidade de construtor;

3) ser o lugar de estudo, de pesquisa e trabalho do planejamento do meio físico nas suas relações diretas com o homem, onde o aluno entrará em contato com os problemas vivos da arquitetura e do urbanismo, na forma mais próxima daquela em que os terá como profissional ..." (MILLÁN, p.37).

O ateliê teria uma estrutura composta por duas "séries" de anos de curso. O $1^{\circ}$ e o $2^{\circ}$ ano integravam a primeira série, a do "Aprendizado gráfico e

${ }^{19}$ Os professores Arquitetos "Carlos Millán, João A. M. Maitre Jean, Gian Carlo Gasperini e Lúcio Grinover (MILLÁN, p.5, grafia original) 
plástico-construtivo"; os três anos subseqüentes a segunda, "Mentalidade de construtor. Formação do arquiteto".

Na primeira série, o ateliê promoveria o "aprendizado gráfico e plástico construtivo", isto é o "domínio dos meios de representação e expressão", através do que foi chamado de "trabalhos horizontais", basicamente trabalhos individuais, "eminentemente práticos", realizados com o desejável "esforço coordenado das cadeiras neles seriados". O objetivo desses exercícios "de composição" seriam de "fixar a nova linguagem e a nova sintaxe que começam a conhecer" e versariam sobre temas restritos - "muito particulares da organização espacial, nos quais possam verificar as implicações de ordem construtiva".

A segunda série seria desenvolvida por meio de duas estruturas: uma, "dos trabalhos horizontais" de caráter individual tendo como temas "a Arquitetura, o Paisagismo e o Desenho Industrial"; a outra, "dos trabalhos verticais", em equipe composta por três alunos da série - um de cada um dos três anos - mais um aluno do $2^{\circ}$ ano, organizada e dirigida pelo aluno do $5^{\circ}$ ano. Os trabalhos versavam sobre temas de "Urbanismo, entendido como 'a prática da coordenação, integração e equipamento do espaço exterior"'.

Além disso, havia uma articulação entre a estrutura horizontal e a vertical: os trabalhos horizontais seriam derivações específicas do trabalho vertical do ano letivo precedente, o qual já fornecia os subsídios e as "formulações gerais" necessário para o desenvolvimento dos primeiros. Assim, não havia necessidade de "novas indagações sobre a razão e natureza do tema e suas relações com o conjunto urbano" e haveria tempo suficiente para um aprofundamento maior dos trabalhos.

Por outro lado, como o funcionamento do ateliê partia da premissa de que a "formação do arquiteto deverá se processar num clima realista", com a imprescindível participação de professores de fora do departamento. Por exemplo, abria-se a possibilidade de que assistentes das cadeiras 
técnicas fossem chamados ao ateliê para "ministrar cursos auxiliares e participar da crítica". As atividades do ateliê também seriam subsidiadas pelo CEPEU - Centro de Pesquisa de Estudos Urbanísticos ${ }^{20}$ - com "elementos para a compreensão das condições nacionais".

Millán concebe o ateliê como departamento mas num sentido diverso de um "departamento" auto-suficiente, como era concebido tradicionalmente, mesmo que tenha uma direção exclusiva exercida "pelo coletivo de seus professores, que fixarão sua organização, seus programas, seus critérios de trabalho e aprovação":

"É da maior importância, para sua plena eficiência, uma colaboração direta e harmônica dos outros departamentos que reúnem as cadeiras técnicas, as cadeiras de história e ciências sociais e o departamento de atividades extracurriculares". (MILLÁN, P.45)

Para Faggin, o ateliê dessa Comissão da visava "simular o funcionamento de um escritório de Arquitetura com equipes verticais de desenvolvimento de projetos", mas integrando-se aos demais departamentos para receber o necessário suporte para as suas atividades. (p.132).

Ainda conforme Faggin, a proposta da Comissão, elaborada para "intervenções imediatas na organização do ensino da FAUUSP" não foi aprovada mas "selava a reforma pedagógica que viria a materializar-se pouco depois na 'Reforma de 62'” e (p.132).

20 Para Fggin, o CEPEU "foi proposto por Millan como o braço de prestação de serviços à comunidade e o verdadeiro laboratório de ensaios das doutrinas gerais experimentadas de maneira acadêmica pela Faculdade" (FAGGIN, P.132). 


\subsection{A "Reforma de 62"}

Nas palavras de Artigas, a proposta de 1962 não só "cumpria decisões das diversas reuniões e congressos sob temas do ensino de Arquitetura organizados dentro do IAB" - o que significava "organizar as escolas em torno do estúdio" -, mas foi "um pouco além" (1993, p.134).

A reforma foi elaborada e aprovada "após numerosos debates entre todos os professores da casa, em fins de 1961" e, basicamente, a nova estrutura curricular incorporou as diretrizes da proposta de 1957, o que significou uma mudança radical e complexa, inclusive a reformulação simultânea da organização acadêmica então vigente em função da Lei de Diretrizes e Bases da Educação Nacional, recém aprovada e que havia introduzido a estrutura departamental no ensino superior.

Segundo Yurgel, a nova estrutura de ensino proposta era integrada por: Departamentos; Biblioteca; Laboratório de Artes Gráficas e de Fotografia; Oficina de Modelos; Museum; ...". O Museum tinha a finalidade de "gerenciar" as atividades extra-curriculares que o GFAU já vinha organizando desde a década anterior ${ }^{21}$, 'bem como os laboratórios e

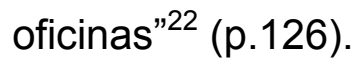

Pretendia-se que essa estrutura, acrescida das novas matérias de projeto e de "todas as áreas de conhecimentos técnicos, históricos, sociais e econômicos, pertinentes ao desenvolvimento de um perfil 'moderno' da

${ }^{21}$ O GFAU promovia "cursos, pesquisas e documentação, publicações, exposições e concerto ... viagens de estudos, ... visitas às obra ...", além de participar de congressos estudantis nacionais e, no âmbito da faculdade, das diversas de suas Comissões. Criou também o Centro de Estudos Folclóricos e a "slidoteca" das obras de arquitetura do Patrimônio Histórico Paulista (YURGEL, p.126)

22 O Museum e o GFAU foram extintos em 1964 pelo Governo Militar (YURGEL, p.126). 
profissão" proporcionasse "uma educação para expressão de um humanismo que reivindica para o arquiteto uma linguagem arquitetônica brasileira, capaz de responder às mudanças da sociedade." (YURGEL, p.126)

\subsubsection{Os departamentos}

Assim, foram criados na FAUUSP os departamentos de "História, Projetos e Técnicas (sic)"23 ou, o Departamento de História da Arquitetura e Estética do Projeto, o Departamento de Projeto e o Departamento de Tecnologia. Cabe observar que esses departamentos foram concebidos como órgãos que devem, certamente, gozar de "certa liberdade de ação, porém não se mantêm estanques" e que devem buscar "áreas de interpenetração" e "tópicos de contatcto no trabalho escolar de todos os dias" (PRADO, p.8).

Aos departamentos cabiam a coordenação do grupo de matérias do currículo a que correspondiam - as antigas ou as que foram criadas com a reforma. O Departamento de Tecnologia apenas " "reuniu" as matérias existentes (PRADO, p.8) que não sofreram modificações, os outros incorporaram matérias novas.

O departamento de história incorporou algumas inovações: "1) estudo de elementos de ciências sociais, com[o] fundamentação da Arquitetura; 2) ... estudo da Arquitetura Contemporânea e da Urbanização ...; 3) ... esforço ... [para a] introduzir o estudo da Estética do Projeto ..." (FAUUSP-b, p.151).

${ }^{23}$ De acordo com o documento "Relatório sobre o ensino de arquitetura no Brasil. UIA-UNESCO", organizado pela FAUUSP, a partir de depoimentos dos professores Flávio Motta João Baptista Vilanova Artigas (FAUUSP-b, p.151). Entretanto, o curso da FUUSP era ministrado por quatro departamentos conforme disposto pela Portaria $\mathrm{n}^{\circ} 122$ da Reitoria da universidade: 0 Departamento de Ciência Aplicada, o Departamento de Construção, o Departamento de História de História e o Departamento de Projeto (PRADO, p.8). 


\subsubsection{Departamento de Projeto}

Os objetivos das reivindicações dos movimentos de reforma do ensino seriam atendidos através da implantação de um espaço, "uma área reservada ... a atividades criativas de 'atelier', laboratórios e oficinas" (MOTTA, p.138), na forma do Departamento de Projeto. Sua organização refletia a complexidade dessa incumbência e incluía grande número de matérias - algumas a serem ainda melhor conceituadas e construídas -, que cobria desde "técnicas" de "comunicação visual" até "matérias" que tinham a responsabilidade de treinar a habilidade de projetação em todo o espectro de trabalho do arquiteto - da casa à cidade e à região, espaços interiores e exteriores (PRADO, p.9).

Para Cintra do Prado as matérias do Departamento estavam organizadas em "quatro linhas de tarefas ou estudos" denominadas "seqüências" porque cada linha desenvolvia os seus temas em ciclos que se sucediam alternando com as demais. As seqüências implantadas pela reforma e citadas por Prado em 1964 foram: Comunicação Visual, Desenho Industrial, Arquitetura e Planejamento (Ibidem, loc.cit.).

Segundo Flávio L. Motta, na Comunicação Visual "a tônica recai sobre problemas de linguagem"; no Desenho Industrial "dominam as preocupações sobre objetos, produtos e sistemas industriais"; no Edifício, sobre "a sistematização de problemas de construção, na área de edifícios e espaços habitáveis"; no Urbanismo e suas implicações, sobre "os problemas das cidades, metrópoles , paisagismo, ocupação territorial" (p.138).

Nas palavras de Cintra do Prado, a comunicação visual corresponde ao "estudo e prática intensiva dos meios de representação - desenho e plástica - disciplinas indispensáveis à formação básica de todo arquiteto, fornecendo-Ihe a técnica necessária para exprimir suas concepções ...; o desenho industrial se destina a "familiarizar o futuro arquiteto com as técnicas da produção industrial" (PRADO, p.9-10). 
Pode-se dizer que essas duas matérias, na realidade são reinserções de preocupações inerentes à arquitetura num novo contexto social.

De fato, a necessidade de uma matéria que fizesse frente ao acelerado avanço técnico e do processo de industrialização já fazia parte da pauta dos primeiros foros de reivindicação dos estudantes e arquitetos da década de 50. Com efeito, o desenho industrial já fazia parte do conjunto de novos "campos da arquitetura" reivindicados no $1^{\circ}$ Seminário do Ensino da Arquitetura realizado em São Paulo em 1958, juntamente com a "decoração, o paisagismo e o planejamento" (CESAR, p.27). Tanto o ${ }^{24}$ quanto o ${ } \mathrm{II}^{25}$ Encontro de Diretores, Professores e Alunos das Escolas e Faculdades de Arquitetura (Belo Horizonte, 1960) reiteram a posição daquele $1^{\circ}$ Seminário de ensino da Arquitetura.

Cabe observar que, ao contrário do desenho industrial, a proposta de comunicação visual não estava presente nas preocupações manifestadas anteriormente, pelo menos nos termos em que foi concebida na FAUUSP. Para Artigas, o curso de comunicação visual, que viria a "substituir um certo número de disciplinas [para o] aprendizado da arquitetura, do urbanismo e do desenho industrial" seria, sobretudo, um "esforço no sentido de aprofundar o conhecimento das imagens artísticas e seu papel na sociedade contemporânea" (1981, p.117).

\footnotetext{
24 “... o desenho industrial e a concepção de objetivos industrializáveis de grande interesse na formação do arquiteto, no que se refere aos projetos de equipamento, móveis e utensílios e à fabricação de elementos de construção, é da maior conveniência seja ele integrado no ensino de arquitetura, completado pelo estudo mais amplo dos problemas de padronização, modulação, normalização e demais processos industriais" (FAUUSP-d, p.-).

25 “... a participação do arquiteto na produção industrial deve ser voltadas para três campos preferenciais:

1) o projeto de bons edifícios industriais;

2) a criação de objetos de formas funcionais e belas;

3) a padronização de elementos construtivos de edifícios, destinada a racionalizar a construção" (Idem, p.-).
} 
A comunicação aqui era "ao nível da arquitetura, ao nível estético" e se referia à capacidade de "informar a sociedade sobre o ... conteúdo e o seu destino" (Ibidem, p.115) da arquitetura e urbanismo, ou das formas arquitetônicas determinadas "a partir de uma valorização mais ampla de seu significado humano" (Ibidem, p116), formas que são, afinal, expressão de "todo um projeto de progresso econômico e social" (Ibidem, p.118). A comunicação daria o instrumental para o arquiteto conseguir "ler" o caos que "a cidade de hoje comunica" e para se contrapor à aceitação da inevitabilidade das "revelações da irracionalidade que a instituiu" e propor a possibilidade de uma "racionalidade de seu existir" e, assim, "projetar a cidade de amanhã" (Ibidem, p.120-121).

Dessa maneira, a estrutura do Departamento de Projeto passou a ser composta por "seqüências de Comunicação Visual, Desenho Industrial, Edifícios e Planejamento Urbanístico" (ARTIGAS 1993, p.135); ou, nas palavras de Marlene Yurgel, pelas "disciplinas" de "Desenho Industrial, Comunicação Visual, Paisagismo, Projeto, em substituição de 'Pequenas e Grandes Composições', Planejamento" (1993, YURGEL, P.126).

É interessante observar a diversidade de denominações utilizadas para identificar tanto as matérias quanto a forma de agrupamento de disciplinas adotada pela FAUUSP ${ }^{26}$. Esse fenômeno, sem dúvida constitui reflexo da sua informalidade do ponto de vista do estatuto ou do regimento da universidade mas também é decorrência de desencontros conceituais causados pela novidade dessas matérias agora incorporadas ao campo da arquitetura.

\footnotetext{
${ }^{26}$ A nomenclatura referente à estruturação do Departamento de Projeto não coincide entre as fontes: em texto de 1973, a reforma de 62 teria caracterizado "quatro linhas básicas de estudo": "Desenho Industrial, Projeto de Edificações, Programação Visual e Planejamento" (FAUUSP-b, p.151); em texto de 1974, a FAUUSP teria subdividido o campo de trabalho em "áreas de interesse": de "Comunicação Visual ...; Desenho Industrial ...; Edificação ...; Urbanismo e suas implicações com os problemas das cidades, redes urbanas, paisagismo e ocupação territorial (1974, MOTTA, p.138). Atualmente, a estrutura da FAUUSP inclui os departamentos de História da Arquitetura e Estética do Projeto, Tecnologia da Arquitetura e de Projeto, este subdividido em áreas de Projeto de Edificações, Planejamento Urbano e Regional, Programação Visual, Desenho Industrial, Paisagem e Ambiente.
} 


\subsubsection{O ateliê de 62}

A Reforma de 62 conseguiu viabilizar o ateliê na "sua verdadeira forma orgânica" (PRADO, p.3), integrando o apoio dos demais departamentos e da infra-estrutura implantada concomitantemente - biblioteca, laboratórios, oficina, museu e o CEPU proposto por Millán (FAGGIN, p.132) e não só constituir-se como "mera oportunidade para expandir as aptidões artísticas do estudante-arquiteto" (PRADO, p.10), mas sendo, isso sim, o verdadeiro centro de formação do futuro profissional (Ibidem, p.11)

Para Cintra do Prado o ateliê de 1962 é

“[...] único, para todos os alunos da Faculdade; e, nele, a prática escolar se processa ciclicamente, por série de aulas que, para o mesmo tema de trabalho, se estendem por dias consecutivos. A existência de um único atelier, a par de alguns inconvenientes de ordem prática, tem certamente a vantagem de estabelecer contacto diário entre alunos e professores de todos os anos, o que redunda em constantes trocas de idéias, amplas e improvisadas, representando repetidas ocasiões para real progresso em conhecimentos. Os programas anuais dos projetos, a desenvolver ali, obedecem a um plano de conjunto para todas as séries do Curso. Assim, a complexidade crescente dos temas vai sendo inserida e vencida naturalmente, no processo do atelier. Os alunos de uma série acompanham, de certo modo, o trabalho dos alunos de outras séries, para diante e para traz, beneficiando-se dest'arte, todos os que realmente estudam e trabalham." (Ibidem, p.9)

Por outro lado, para racionalizar a contribuição das diversas áreas de conhecimento, do próprio ateliê e de outros departamentos, havia a necessidade de distribuir as diversas matérias de acordo com a programação do ateliê, conforme descrição de Cintra do Prado:

"[...] as matérias de ciência aplicada existem em grande número na primeira série; há somente uma ou duas delas na segunda; daí por diante não figuram 
mais. As disciplinas do Departamento de Construção, às vezes chamadas 'de aplicação técnica', distribuem-se com relativa uniformidade desde a primeira até a quarta série, e estão ausente na. última. Por outro lado, a formação históricosociológica principia com pouca matéria na primeira série, apresenta intensificação crescente até o quarto ano do Curso, e prolonga-se atenuada na última série. $O$ trabalho do atelier, esse é praticamente constante, de ponta a ponta, e ocupa cerca de $50 \%$ do tempo disponível do horário, em todas as séries."

De conformidade com este esquema, as primeiras tarefas do atelier correspondem sobretudo ao aprendizado das técnicas de comunicação visual. 0 projeto começa por temas simples, as chamadas 'pequenas composições', e permanece nessa escala durante os dois anos do curso, enquanto o estudante, vai formando o seu cabedal de conhecimentos científicos, técnicos e históricoeconômicos. Do terceiro ano em diante, os projetos enveredam por temas mais amplos e mais complexos - 'as grandes composições'. À medida que o estudante avança no curso, vai acumulando conhecimentos que o habilitam a dominar problemas mais árduos de Arquitetura, ao mesmo passo que, [...] dispõe de maior capacidade criadora pra formular as soluções." (p.10-11)

\subsubsection{Trabalho de graduação}

Outra proposta incorporada pelo currículo da FAUUSP, que se tornaria padrão para o ensino de arquitetura no Brasil, é o trabalho de conclusão do curso implantado em 1968 com o nome de "Tese de graduação" e que tiveram como seus primeiros professores João Batista Vilanova Artigas e Paulo Mendes da Rocha. A TG, na realidade, representava um desdobramento do trabalho do último ano já previsto na estrutura da Reforma de 62 e no qual os alunos desse ano do curso deveriam desenvolver em equipe e com orientação de professores "temas gerais que incluem aspectos urbanísticos e paisagísticos, realizando aquilo que os programas definem como 'a prática de coordenação, integração e equipamento do espaço exterior'." (PRADO, p.10). Exemplo típico desse 
tipo de trabalho foi o projeto do porto da cidade de São Sebastião, no Estado de São Paulo, desenvolvido em 1966.

Se este trabalho era coletivo e tinha um tema pré-estabelecido, o novo TG dele se diferenciava por ser individual e pela livre escolha do tema por parte do aluno.

Cabe observar, entretanto, que a TG da FAUUSP não foi a primeira experiência no gênero no país, pois "o trabalho-tese já era uma experiência consagrada" na FAUFRGS, conforme observa Miguel Pereira. Com efeito, já em 1957, como resposta a uma "aspiração generalizada", havia sido designada uma comissão para "discutir o então chamado trabalho de diplomação, [...] coroando, no $5^{\mathrm{a}}$ ano, toda a seqüência do curso" e que seria denominado "trabalho-tese" no plano de reforma proposto pela FAU/RS.. O trabalho constituía o último dos três segmentos de seu novo curso, iniciado com um ciclo básico de dois anos, "dedicados aos conhecimentos básicos da formação do arquiteto" e seguido de um ciclo profissional de cinco semestres. Era um trabalho que culminava um curso que, como a FAUUSP, tinha uma maior presença de matérias técnicas no seu início e o ateliê como elemento de estruturação (2005, p.113-114).

Tanto em São Paulo como em Porto Alegre, o significado maior desse tipo de trabalho era abrir a possibilidade para o aluno vivenciar uma aproximação com a realidade da profissão, além de poder realizar uma síntese final e a transição entre a escola e a vida prática. Nessas condições, os problemas eram "equacionados e estudados" com alto senso de responsabilidade contribuindo "decisivamente para fortalecer no estudante o conceito verdadeiramente universitário de sua profissão" (PEREIRA, p.114).

A evidência da importância do trabalho de conclusão do curso, na FAUUSP rebatizado como "TGI" - Trabalho de Graduação Interdisciplinar 
-, levou, posteriormente, a que fosse exigido por força de lei, com o nome de "Trabalho final de graduação" - "TFG" e agora, "Trabalho de Curso" 27. Além disso, justificou a criação de um concorrido concurso nacional.

${ }^{27}$ Portaria $n^{\circ} 1.770$ / 1994 do MEC; em 2006, foram aprovadas as novas diretrizes curriculares para o curso de arquitetura e urbanismo, que mudou o nome TFG para "TC" - Trabalho de Curso (MEC, CES, Resolução n 6, 2006) 


\subsection{O "Fórum de 68"}

A estrutura curricular da reforma de 1962 se manteve ao longo de uma década e meia apesar do desgaste natural no plano interno da escola que aprofundou paulatinamente os problemas já agravados pelos efeitos da Reforma Universitária decretada em fins de 1968.

A primeira tentativa de revisão aconteceu na forma de um fórum realizado em meados de 1968, o "Fórum de 68", para "rever os métodos de ensino de todos os departamentos e propor uma estrutura global de ensino e pesquisa" (FAUUSP/MUSEU, p.1-2) ou, "restabelecer as diretrizes de 62" (ARANTES, p.91).

Ao cabo de amplos debates e trabalhos de diversas comissões foram aprovadas várias medidas. Em termos da graduação, métodos e programas foram revisados para melhor articular as atividades dos quatro departamentos e das seqüências de cada departamento; introdução do "processo de pesquisa" como meio de conhecimento ao invés de sua simples transmissão em aulas expositivas; implementação do "sistema de unidades de ensino básicas e alternativas de duração variável", desenvolvendo, respectivamente, campos de conhecimentos de interesse mais geral e específicos da arquitetura; estabelecimento de "temáticas básicas" para organizar as atividades de ensino e pesquisa ${ }^{28}$.

Outra decisão propunha ampliar o curso de pós-graduação e instituir um curso regular de mestrado.

Foram aprovadas várias medidas para a promoção da pesquisa com a finalidade de formar quadros para a escola e fortalecer a posição da FAU

${ }^{28}$ O primieor tema proposto foi "Arquitetura e sociedade de consumo" (FAUUSP/MUSEU, p. 1) 
e da Universidade perante a sociedade no tocante aos problemas da arquitetura e do urbanismo: foi criado o "Atelier Interdepartamental" como espaço para o desenvolvimento de pesquisas de "alto nível com caráter interdepartamental"; o CEPEU, Centro de Pesquisas Urbanísticas deveria ser reorganizado para transformar-se de mero prestador de serviços de planejamento em órgão de pesquisas básicas para o suporte conceitual e metodológico dos trabalhos profissionais não acadêmicos.

Foi decidida também a reabertura do Museu, agora com funções ampliadas: além de organizar as atividades extra-curriculares da escola como palestras, debates e exposições - e orientar os laboratórios e bibliotecas, passaria a "programar, coordenar e divulgar as atividades curriculares e extra-curriculares de ensino e pesquisa, tanto da graduação como da pós-graduação.

O Fórum de 68, segundo Luiz Carlos Daher, não produziu maiores conseqüências para a essência da organização do ensino da FAUUSP. Apesar dos "intensos debates, diferenças aguçadas em controvérsias e polêmicas" e as propostas aprovadas no seu final apenas "se contiveram em estimular certa flexibilidade e certo realismo critico", apoiando a posição de Vilanova Artigas (p.160).

A propósito, ainda que considerasse essas polêmicas um avanço no sentido de que elas possibilitavam "discutir a unidade de propósitos a partir de divergências" dentro da própria escola sobre como conduzir seus processos, Artigas não concordava com a proposta de um grupo de professores que tinha por objetivo tentar mudar radicalmente a arquitetura brasileira, a qual, "apesar das melhores intenções ou resultados obtidos, nada conseguira que provasse ou instituísse os seus propósitos democráticos e humanísticos". Para esses professores, uma vertente de ação nesse sentido seria a educação, onde deveriam ser construídas novas "técnicas e uma conceituação de educação de arquitetos" no ensino da FAUUSP. Para Artigas, ao contrário, tratava-se de continuar a 
manter "a orientação descolonizadora" pela qual sempre se bateu e para a qual havia proposto uma prática escolar (1993, p.135-136).

Reivindicavam tais professores maior "aproximação do trabalho do ateliê com a realidade empírica, a fim de municiar uma compreensão concreta da realidade" através de "encomendas obtidas de algum modo - na Prefeitura por exemplo", mas contra essa proposta foram levantados alertas com relação ao risco de expor o conteúdo dos currículos aos interesses privados, ao mesmo tempo em que tal procedimento poderia se caracterizar como uma indesejável concorrência com a atividade profissional (DAHER, p.160).

Nesse sentido, o Fórum de 68 constituiu a culminação de uma certa polarização ideológica que, segundo Faggin (p.132), começou a se delinear, no processo da reforma de 1962, entre duas posições antagônicas do ponto de vista profissional, representadas pelo "documento de Millán" e a "reforma de Artigas":

“[...] a primeira entende que a Arquitetura é uma profissão e deve ser vista como uma atividade para cujo exercício se recebe treinamento específico. A segunda entende que a Arquitetura é uma atividade intelectual e por isso passível de pressões resultantes de ideologias diversas, da esquerda à direita. Esse aparente maniqueísmo obstacul[iz]ou um efetivo entendimento entre as propostas de Millán e as de Artigas." (FAGGIN, loc.cit.)

De fato, no Fórum de 68, aconteceu, segundo Pedro Arantes (p.92 et.seq.), basicamente, o confronto ético e político entre um grupo de professores $^{29}$. Foi questionada "a possibilidade de fazer oposição ao regime militar dentro do campo estrito da arquitetura e da prática profissional" - e, inevitavelmente, no campo do ensino profissional - ao invés de uma ação profissional "acima de qualquer outra". Tratava-se, grosso modo do confronto entre "a busca prioritária do desenvolvimento

\footnotetext{
${ }^{29}$ Flávio Império, Rodrigo Lefèvre e Sérgio Ferro, que lideravam a chamada "geração da ruptura" (ARANTES, p.92).
} 
das forças produtivas em arquitetura" defendida por Artigas e "a critica das relações de produção e de exploração" (FERRO, apud ARANTES, P.3) daquele grupo de professores. A essa crítica foi contraposto o argumento de que uma ação exclusivamente no plano político inviabilizaria a ação possível no plano da profissão, com seu "conhecimento técnico" e sua "visão artística do mundo" - e, por extensão, a ação no ensino -, e significaria o abandono da prática profissional e o fechamento da escola.

A resposta prática a esse questionamento foi dada posteriormente, quando dois de seus autores formuladores aderiram à luta armada para resistir à ditadura: era preciso agredir mais contundentemente, era preciso abandonar a prática profissional. A opção era, portanto, entre o "lápis e o fuzil": quem empunhava o fuzil o empunhava não como arquiteto, mas como cidadão; o cidadão que optava pelo lápis só poderia agir através de sua profissão.

Posteriormente, Artigas, dirá que os fatos provaram seu acerto em ter defendido o papel "progressista e emancipador" da Arquitetura, alinhada com as "lutas de todo o nosso povo" (1993, p.134). Por sua vez, Rodrigo Lefèvre, critico dessa posição na ocasião relativiza a polêmica numa entrevista:

“[...] começaram a falar que existiam arquitetos que diziam que não se devia trabalhar na prancheta, que não se devia produzir desenho. Não era nada disso. Simplesmente nós achávamos que talvez fosse importante, em um certo momento, pensar um pouco e aprender a pensar um pouco antes de fazer alguma atividade profissional." (KOURY, p.198, apud ARANTES, p.93)

Apesar da intensidade dos debates, os resultados concretos do "Fórum de 68" se caracterizou mais pelo "enfoque da diversificação profissional" (PEREIRA 2005, p.114), o que significou, na prática, a atribuição de "novas tarefas aos grupos de disciplinas já existentes", especialmente para o Departamento de Projeto (DAHER, p.160). Por exemplo, o grupo 
de Comunicação Visual desse departamento deveria assumir um "curso completo de emprego de meios de comunicação visual", sem se "limitar ao 'exercício', mas ao projeto concreto" de peças gráficas e de identidade visual - cartazes, embalagens, livros, marcas, etc. (ARTIGAS 1998, P.34).

Para Artigas, a proposta central de 1968 era "integrar o curso de forma a não precisar mais da concentração em torno do estúdio", reformulando "um departamento de estudos técnicos de construções e lhe definir o caráter, o significado, a linha de pesquisa possíveis" e estudando "a definição para o estudo das ciências humanas no Departamento de História", além de modificar o "estúdio, tornando-o mais maleável do que era" (1993, p.136).

Muitas das propostas do Fórum de 1968 foram "desenvolvidas, outras tornara-se inviáveis ${ }^{30}$ [...] entretanto, todos os avanços possíveis naquele período conturbado" foram inibidos pelo quadro político que se desenhou a partir da decretação do Ato Institucional $n^{a}$ 5: a universidade, assim como toda a sociedade, foi alvo de atos de autoritarismo, entre os quais a aposentadoria de seus professores mais progressistas, entre os quais 27 pertencentes à USP, três deles da $\mathrm{FAU}^{31}$, o movimento estudantil foi reprimido e, em novembro daquele ano, foi decretada a Reforma Universitária (DAHER, p.160-161).

\footnotetext{
${ }^{30}$ O relatório apresentado pelo Museu ao fórum que seria realizado em 1969 já anunciava algumas dificuldades: "O Atelier Interdepartamental foi talvez o setor no qual menos progresso se conseguiu [...]" em razão do desinteresse geral e da falta de verbas para sua operacionalização. (FAUUSP/MUSEU, p.7-8).

31 João Batista Vilanova Artigas, Paulo Mendes da Rocha e Jean Maitrejean.
} 


\subsection{A Reforma Universitária}

A Reforma Universitária (Lei $n^{\circ} 5.540$ de 28.11.68) constituiu, sem dúvida, o acontecimento mais decisivo da curta história do ensino superior brasileiro. Para Marilena Chauí (2001, p.47 et seq.), a Reforma Universitária foi imposta para "resolver a "crise estudantil", delineada pelo Relatório Meira Mattos (1968) como sendo de "falta de disciplina e de autoridade" no campo da educação superior e na qual a autonomia universitária era considerada um "privilégio para ensinar conteúdos prejudiciais à ordem social e à democracia". Propunha também o relator medidas práticas e pragmáticas que pudessem se tornar "instrumento de aceleração social e da expansão de oportunidades, vinculando a educação aos imperativos do progresso técnico, econômico e social do país" (Apud CHAUÍ, 1977, p.17).

O plano político da questão foi encaminhado pela edição de medidas eficazes de repressão representadas pelo Ato Institucional $n^{\circ} 5$ e pelo Decreto $n^{\circ} 477$ - aquele de caráter geral e este destindo especificamente à comunidade acadêmica -, para assegurar as condições necessárias para a solução da crise no plano social, traduzidas por fortes "demandas de ascensão e prestígio sociais da classe média que apoiara o golpe de 64". Para tanto havia urgência em ampliar grandemente o número de vagas do ensino superior, mas "com o 'máximo rendimento' e a 'mínima' inversão"' (p.47 et seq.), num enfoque quantitativo como havia sido sugerido pelo Relatório Atcon (1966) e oepracionalizado por algumas medidas muito precisas de caráter eminentemente técnico.

"Uma primeira modificação importante foi a departamentalização. [...] Consistiu em reunir num mesmo departamento todas as disciplinas afins, de modo a oferecer cursos num mesmo espaço [...] e sem aumentar o número de 
professores. [...] Além de diminuir os gastos, a departamentalização facilita o controle administrativo e ideológico dos professores e alunos.

Outra modificação foi a matrícula por disciplina (o curso parcelado e por créditos), que leva a uma divisão das disciplinas em obrigatórias e optativas, mas fazendo que as obrigatórias para um aluno possam ser optativas para outro, de modo que alunos de cursos diferentes possam seguir a mesma disciplina, ministrada na mesma hora pelo mesmo professor numa mesma sala de aula. Segundo o texto da reforma, essa operação visa aumentar a 'produtividade' do corpo docente, que passa a ensinar as mesmas coisas para maior número de pessoas.

Foi inventado o curso básico. No texto da reforma, [... para ...] o melhor aproveitamento da 'capacidade ociosa' de certos recursos, isto é, daqueles cursos que recebem poucos estudantes e dão prejuízo ao Estado, além de evitar o crescimento do corpo docente naqueles cursos que recebem grande quantidade de alunos e que exigiriam a contratação de maior número de professores. Ocupando vários professores dos cursos 'ociosos' no básico, o prejuízo desaparece e não há necessidade de gastos com outras contratações. $[\ldots]$

A unificação do vestibular por região e o ingresso por classificação tiveram a finalidade de permitir o preenchimento de vagas em cursos pouco procurados, forçando os alunos à opção, quando não o força a matricular-se nas escolas particulares que, sem tal recurso, seriam menos procuradas. $O$ curso básico e $o$ vestibular unificado produzem o que a reforma do ensino denomina 'unificação do mercado de ensino universitário'”. (CHAUÍ, p.48-49)

A departamentalização caracterizava um processo de reestruturação "administrativo-pedagógica" e possibilitava substituir as unidades acadêmicas isoladas e estanques além de "eliminar a duplicidade de trabalhos" e de disciplinas, aumentando a taxa de utilização dos recursos de espaço, instalações e professores" além daqueles referentes ao controle administrativo (SINOPSES MEMÓRIA, p.145). Os departamentos extinguiam e substituíam as cátedras, uma "velha reivindicação dos estudantes e dos setores avançados do professorado" e 
passaram a representar a "menor fração na direção do ensino" (DAHER, p.161).

Por sua vez, a "matrícula por disciplinas (regime de créditos)" contribuía para o objetivo de redução de custos do ensino porque os alunos "não mais se matriculariam em todo o conjunto de disciplinas, constituindo uma série", mas o faziam em cada disciplina, "compondo" o currículo conforme as disciplinas oferecidas - obrigatórias e optativas, ou eletivas -, de acordo com seus interesses "intelectuais e profissionais" e com os prérequisitos estabelecidos (SINOPSES MEMÓRIA, p.145).

Foram criados também cursos de graduação de menor duração, "correspondendo a uma parcela da habilitação" do curso completo. Naturalmente essa fragmentação do ensino visou oferecer alternativas para atender a demanda de vagas, "sempre a custos adicionais reduzidos" (Ibid., p.146).

Algumas dessas medidas foram abandonadas por autoritárias (por exemplo, o condicionamento da representação discente ao aproveitamento escolar). Com relação àquelas consideradas "efetivas", como a extinção da cátedra, revelou-se que "eram irrelevantes diante do conjunto de medidas, que parecia uma rancorosa vingança contra os espíritos críticos que animaram as universidades de todo o Brasil" (DAHER, p.161).

Segundo Maria de Fátima de Paula (p.117-119), as principais medidas integrantes da Reforma Universitária coincidiam formalmente com parte das reivindicações da comunidade acadêmica mas reelaboradas "numa chave conservadora", a partir da "lógica racionalizadora do capital" 32.

\footnotetext{
${ }^{32}$ Estudioso há que considera ter havido algum saldo positivo nas conseqüências produzidas por essa ingerência do governo militar na universidade brasileira. Segundo Luiz Antônio Cunha, "a reforma do ensino empreendida em 1968, bem como dos documentos legais que as antecederam, propiciaram condições institucionais para a efetiva criação da instituição universitária no Brasil, onde, até então, existiam somente faculdades isoladas ou
} 
Com efeito, o projeto do Ministério da Educação e Cultura visava a construção de "uma maior eficiência e racionalização" de caráter eminentemente empresarial no ensino superior, inaugurando um política marcada pela "disposição de imprimir uma instrumentalidade à vida acadêmica", e que se traduziu

"[...] nas novas concepções de trabalho intelectual, de avaliação da universidade e da 'produtividade' dos professores universitários, de financiamento de pesquisa, de pós-graduação, de prestação de serviços à sociedade, etc."

Dessa maneira, as universidades deveriam passar a priorizar as "demandas extra-universitárias, principalmente àquelas originárias do campo econômico", então no início do processo globalização. Nas palavras de Arabela Campos Oliven (Apud PAULA, p.118):

"a questão da relevância social da universidade passou a ser aferida tendo como critério central o comportamento do mercado. Assim, ensino e atividade de extensão passaram a ser percebidas apenas como mercadorias que podiam ser adquiridas por aqueles que almejassem um diploma, um certificado de aperfeiçoamento, uma consultoria... A própria pesquisa nas universidades, criadas como fundações, passara a ser concebida como algo vendável. [...] A universidade toma, desta forma, a empresa capitalista como modelo. Volta-se para atender a demanda e deixa de lado as necessidades sociais mais prementes, pois para tal atendimento não existe procura no mercado, na forma de remuneração aos serviços prestados" (OLIVEN, p.55).

ligadas por laços mais simbólicos do que propriamente acadêmicos. ... Sem desconsiderar as danosas conseqüências que a ditadura militar (1964-82) teve na vida acadêmica, não é possível deixar de levar em conta o fato de que foi nesse período que o processo tardio de formação da universidade brasileira recebeu o maior impulso" (In: LOPES, FARIA e VEIGA, p.178). O que deve ser lembrado é que o o processo que foi truncado também continha, em seu bojo, alcance e objetivos equivalentes mas com sentido inverso ao de dominação. 
3 FAUUSP após a Reforma Universitária 


\subsection{0 "Fórum de 78"}

\subsubsection{A integração proposta}

Decorridos quinze anos da grande Reforma de 62, o ensino da FAUUSP vivia uma situação descrita por alguns alunos como sendo de "insatisfação generalizada entre professores, alunos e funcionários", distante do "projeto formulado pelos fóruns de 1962 e 1968"

"[...] não porque estivessem equivocadas em suas formulações, mas porque, de lá para cá, uma nova configuração da sociedade brasileira coloca para o arquiteto, a necessidade não só de redefinir seu campo de atuação profissional e política como também sua própria formação." (PROPOSTA, p.13)

Em termos de ensino, o problema maior e reconhecido quase consensualmente era a fragmentação em uma multiplicidade de disciplinas, o que implicava uma sobrecarga para os alunos, obrigados a desenvolver grande número de atividades e tarefas, muitas delas de forma simultânea.

Nesse período não foram poucas as tentativas visando reverter esse visível processo de deterioração do ensino da escola: o fórum de 1968, os fóruns mais restritos de 1969, 1970 e 1971, a retomada das discussões em 1976 não tiveram resultados mais significativos e, para Zanettini, "serviram mais como indicadores da necessidade de alterações substantivas" (1980, p.20). Para fazer frente a esse quadro, cuja gravidade era reconhecida de modo quase consensual, a FAUUSP convocou o último dos seus fóruns em 1978.

Já em 1977, o relatório da Comissão de Reestruturação Curricular (COMISSÃO, p.3 et seq.) reconhecia a "fragmentação e parcelização" do 
conhecimento da arquitetura ali ministrado, decorrente da "atomização das disciplinas, conteúdos e trabalhos". No entendimento da comissão, não teria havido uma coordenação competente no sentido de para articular, em um conjunto equilibrado e harmônico, as reformulações parcelares introduzidas pelas seqüências e departamentos da escola desde a reforma de 1962.

Assim, todas as disciplinas, independentemente do departamento a que pertenciam, passaram a manter um conteúdo exclusivo e estanque, que era ministrado e avaliado de forma autônoma com relação aos conteúdos das outras disciplinas. Nessas condições, era inevitável que a cada disciplina correspondesse, pelo menos teoricamente, um trabalho a ser elaborado pelo aluno simultaneamente com os trabalhos das demais disciplinas,

"a ponto de um mesmo aluno ter que produzir cerca de 12 trabalhos, às vezes completamente diferentes uns dos outros, além de ter que assistir às aulas, e elaborar sumários de suas leituras" (Ibidem, p.4)

A conseqüência natural dessa situação se traduzia em trabalhos que permaneciam em uma "superficialidade atomizada [...] incompatível com os objetivos que a FAU se propõe para a formação do aluno".

Os alunos tinham plena consciência da atomização dos departamentos, tanto no seu interior quanto nas relações entre si (ENSINO, p.44-45). Para eles, "a mais completa fragmentação expressa na desconecção das disciplinas", gerou a situação descrita como sendo de "total superficialidade do ensino" e de "total escamoteamento da realidade" (Ibidem, p.53).

Diferenças de ênfases e de operacionalização à parte, a quase unanimidade com relação ao problema a ser superado alinhou de forma natural as propostas apresentadas ao fórum na direção tanto do resgate 
da unidade do ensino, então fragmentado quanto da articulação dos trabalhos isolados das disciplinas.

Para reduzir o número de tarefas se defendeu a criação de trabalhos que conseguissem integrar os conteúdos de várias disciplinas. Alguns alunos, por exemplo, propuseram que o Departamento de Projeto desenvolvesse um trabalho único por turma, o "projeto interdisciplinar", complementado por quatro disciplinas optativas, de três tipos - as de "aprofundamento do [...] projeto", as de "pesquisa" e as "vinculadas ao projeto interdisciplinar" (PROPOSTA, p.20, 25-26). Um outro grupo de alunos sugerem medida semelhante ("trabalho único"), mas coordenado por comissões horizontais e verticais (CORPO, passim).

Já um professor, apesar de considerar insuficientes as demais propostas, no que se refere a recomendações como a criação de comissões de coordenação e projetos interdisciplinares, propõe a introdução de um "trabalho fundamental e principal", que seria desenvolvido sobre uma problemática a ser escolhida pelo aluno dentre outras pré-estabelecidas, numa estrutura curricular que tem a "presença de todos os setores da FAU", isto é, os Departamentos de História, Tecnologia, "outros" e Projeto, com as suas seqüências - "Projeto Edifício", "Projeto Planej.", "Projeto PV", "projeto DI". Além deste "trabalho fundamental”, cada disciplina poderia "propor o desenvolvimento de trabalhos próprios para cumprir seu programa e atingir seus objetivos", os trabalhos "subsidiários". (DENTE, p.-)

A Comissão de Reestruturação Curricular, por sua vez, apontava a urgente necessidade de estabelecer uma "articulação horizontal" e uma coordenação entre as disciplinas tanto de um único departamento quanto de diversos departamentos, principalmente as obrigatórias - que normalmente têm turmas maiores -, numa expectativa de que os trabalhos fossem desenvolvidos com "níveis de profundidade e de complexidade compatíveis com o perfil do arquiteto pretendido": 
“[...] os professores destas disciplinas dos 3 departamentos deverão estabelecer uma coordenação entre conteúdos, atividades e trabalhos de cada uma das disciplinas [...] tendo em vista alguns objetivos além dos objetivos gerais buscados pelo ensino na FAU: por um lado uma diminuição do número e dos tipos de trabalhos a serem feitos pelos estudantes e, por outro, uma conexão entre os trabalhos tal que, enquanto eles elaboram um deles, para qualquer das disciplinas, estejam ao mesmo tempo pensando, investigando, problematizando os temas das demais obrigatórias." (Ibidem, p.4)

A ênfase dada pela Comissão para a idéia de "coordenação" e não de "integração" entre disciplinas é justificada por seu entendimento de que deva ser mantida a "única coisa [...] importante e necessária" da situação fragmentária anterior ou seja, a diversidade assegurada pelas mais diferentes "concepções e orientação" de grande número de professores com quem o aluno conseguia ter contato, diversidade que sem a necessária coordenação poderia ser chamada de "caos, de anarquia, de individualismo, de liberalismo" (Ibidem, p.5).

Entretanto, ao mesmo tempo em que defende a coordenação, em detrimento conceito de integração das disciplinas, a Comissão, ambiguamente, recorre ao mesmo conceito - integração -, invocando o próprio regimento da Universidade. O relatório transcreve o parágrafo $3^{a}$ do Artigo 96 que prevê o assim chamado "conjunto de disciplinas" que

"corresponde a programa de ensino, com enfoque multidisciplinar que deva ser ministrado [...] de maneira integrada (isto é, de maneira coordenada). Neste caso, a avaliação do aprendizado será feita com base no programa integrado (coordenado) do conjunto de disciplinas" (Ibidem, loc.cit.).

A Comissão propõe valer-se "dessa formalidade" como recurso para que os alunos "cursem ao mesmo tempo disciplinas coordenadas dos 3 Departamentos, que formarão 'um conjunto de disciplinas', sem perderem suas autonomias". Essas disciplinas seriam as "obrigatórias interdisciplinares" de ateliê do Departamento de Projeto (Ibidem, p.5-6), uma vez que a Comissão acreditava "ser a atividade de projeto o 
elemento deflagrador do processo de conhecimento do aluno de Arquitetura" (Ibidem, p.3).

Apesar da concordância das partes envolvidas com relação ao problema central a ser resolvido, o fórum conseguiu aprovar apenas uma proposta de integração das disciplinas de caráter genérico e indicativo, designando uma comissão técnica para sua operacionalização. A proposta apresentada por esta comissão foi sumariamente rejeitada pela Congregação alguns meses depois e somente no ano seguinte a pressão dos estudantes e professores conseguiu aprovar a versão final da proposta.

\subsubsection{A integração na prática}

A reforma, finalmente implantada em 1980, prescrevia, basicamente, o remanejamento de toda a grade curricular do curso, com exceção dos dois últimos semestres, por sinal reservados ao "TGl" - trabalho de graduação interdisciplinar, a antiga "TG”, tese de graduação.

Acreditava-se que quanto mais disciplinas fossem integradas melhor seria o resultado da mudança mas, paradoxalmente, foi mantida a autonomia curricular e didática dos departamentos, tanto que não havia previsão de quaisquer instrumentos para que promovessem a integração interdepartamental. Sendo assim, a reforma foi implementada isoladamente dentro de cada cada departamento, e a integração era implmentada apenas entre suas disciplinas. Assim, o nível de integração variou de departamento a departamento, porque neles existiam disciplinas com carga horária semanal insuficiente para ser subdividida, o que, de acordo com essa visão, era a condição necessária para a integração. No Departamento de Tecnologia da Arquitetura, por exemplo, foi criado apenas um conjunto seqüencial de oito semestres de "Tecnologia da Construção" para promover a integração com outras disciplinas de carga horária menor. 
O Departamento de Projeto foi o único que teve condições para implementar integralmente a reforma, já que havia um equilíbrio na distribuição de carga didática entre os seus quatro grupos de disciplinas ao longo de ${ }^{33}$ todos os oito semestres. Essa característica única desse departamento veio a facilitar o desdobramento das disciplinas e todas elas puderam ser alocadas em todos os semestres do curso, criando a condição para se integrarem.

Na grade anterior cada um desses grupo ministrava aulas de duas por semana em semestres alternados, somando quatro semestres durante o curso e, com a reforma, passou a fazê-lo com uma única aula semanal de uma tarde mas em oito semestres. A quinta tarde da semana era dividida entre as disciplinas optativas e aulas de Paisagismo, ainda pertencente ao grupo de planejamento.

A idéia contida na operacionalização da reforma era de que, com esse remanejamento da grade, o número de trabalhos do Departamento de Projeto fosse reduzido dos anteriores três (os de duas obrigatórias e uma optativa) para dois (o integrado e o de uma optativa). Assim, se assegurariam as condições requeridas para que os temas propostos fossem desenvolvidos com maior profundidade e, sobretudo, enriquecidos pela contribuição dos professores de todos os grupos do Departamento.

Com a implementação da reforma e as subdivisões por ela exigidas, o Departamento de Projeto aumentou substancialmente seu número de disciplinas, que passou de 20 para 41 ou $105 \%$ a mais que antes do Fórum ${ }^{34}$ e de 15 para 36 , um aumento de $140 \%$ se forem consideradas somente as obrigatórias, enquanto nos demais departamentos os

\footnotetext{
${ }^{33}$ Grupos de disciplinas de Projeto de Edificações (GDPr), Planejamento GDPI), Desenho Industrial (GDDI) e Programação Visual (GDPV).

${ }^{34}$ Das 65 disciplinas que eram ministradas antes da reforma, 11 eram optativas e duas, trabalhos de graduação - TGI; desse total, 20 eram de responsabilidade do Departamento de Projeto, das quais 5 eram optativas. Após a reforma esses números passaram a ser de 94 incluindo 12 optativas e duas de TGI em todo o curso; 41 incluindo 12 optativas no Departamento.
} 
números foram de 50 para 58 , ou um incremento de apenas $16 \%$. Já no curso da FAUUSP como um todo, o aumento foi de 65 para 94 ou de $44,6 \%$.

Entretanto, bastaram poucos meses para se perceber que o resultado foi exatamente o agravamento do problema que se tentou resolver. A situação a que chegou nesse momento é descrita por uma carta aberta de uma professora do primeiro semestre ${ }^{35}$.

"Como dizem os estudantes a situação é caótica, tal o número de trabalhos, exercícios, provas e seminários que se superpõe a cada semana, sendo que eles (os alunos) têm aulas todas as manhãs e todas as tardes. A novidade em relação aos anos anteriores é que em nome da integração fragmentou-se o currículo a níveis talvez insuportáveis a médio prazo: novas disciplinas foram criadas, [...] todas as disciplinas de projeto que ocupavam apenas um semestre, concentrando a carga horária, agora tem essa carga pulverizada pelo ano todo. São cinco disciplinas, só no ateliê. Como não há integração entre as 15 disciplinas, cada uma fecha-se em seu universo tentando constituir um todo coerente com começo, meio e fim, abordando, alguma, aspectos teóricos e práticos.

Para que o colega tenha uma idéia da irracionalidade do conjunto, embora cada parte seja extremamente coerente e racional em si, anexamos uma relação dos trabalhos que os alunos são obrigados a fazer, além das 8 horas de aulas diárias. Os alunos chegaram mesmo a afirmar que receberam a proposta de greve na USP com alívio, pois finalmente teriam tempo de estudar, ir à biblioteca, ir aos laboratórios, sem a obrigação de executar tarefas imediatas sem interesse. O resultado qualitativo dos trabalhos assim executados deixa muito a desejar segundo eles. $E$ foi justamente o precário desenvolvimento do trabalho na minha disciplina, levou-me a buscar as causas do mesmo e envolver-me com esta questão.

O mais grave dessa dinâmica de cumprir tarefas, é a deterioração da relação aluno-professor e aluno-escola e o comprometimento da qualificação do aluno.

${ }^{35}$ Ermínia Maricato, carta de 19.05.1980. 
O aluno inicialmente tão motivado se desilude paulatinamente com o ensino na escola, passa procurar os escritórios e a fajutar entrega de trabalhos. É claro demais o descontentamento do aluno do 3.0 ano em diante para com a escola, para que eu me ocupe de sua demonstração aqui. A questão que levantamos é, se não nos cabe parte da responsabilidade desse processo, com o extremo individualismo com que conduzimos cada disciplina (falo de modo geral e não me prendo a alguns casos particulares) acarretando superposição de tarefas extra-aulas, algumas das quais fazendo parte do programa de duas disciplinas, sem que os professores se dêem conta."

Com efeito, no Departamento de Projeto especialmente, somente umas poucas disciplinas com metodologias e conteúdos próximos conseguiram viabilizar um trabalho comum. Mas, mesmo nesses casos e principalmente no conjunto das demais disciplinas, os conteúdos especificos originais não puderam ser ministrados integralmente porque elas seriam obrigadas a participar do trabalho interdisciplinar. Houve mesmo disciplinas que, para colaborar neste trabalho, tiveram que abrir mão do seu projeto curricular individual e atuar de forma subalterna em relação às outras, o que as levou a se desengajarem da reforma implantada.

Com o correr do tempo, outras disciplinas foram retomando seus conteúdos específicos, mas, apesar disso e apesar da crítica generalizada, a nova estrutura foi mantida formalmente, consolidando a fragmentação e aumentando a sobrecarga dos alunos, que passaram a desenvolver concomitantemente, além do trabalho interdisciplinar, os trabalhos específicos de todas as disciplina do departamento. Se antes da reforma os alunos tinham que dar conta de até 12 trabalhos simultâneamente, com a integração, esse número poderia chegar a 16 um para cada uma das 13 disciplinas mais os interdisciplinares que poderiam chegar a três, considerando que cada departamento poderia implementar o seu. 
Tais condições vieram a inviabilizar de vez qualquer possibilidade de dedicação e de aprofundamento da formação dos alunos. O ensino do departamento se deteriorou e o descrédito em que caiu a reforma atingiu tal ponto que , ao fim de alguns anos, sua proposta central - a integração - passou a se restringir a algumas poucas iniciativas isoladas.

Não se conseguiu, portanto, superar a barreira da segmentação das disciplinas, até porque a especificidade e a parcelaridade de seus conteúdos são condições estruturais de sua existência e também porque a própria estrutura da universidade se baseia na disciplinaridade do conhecimento $^{36}$.

Uma das razões, senão a mais determinante do que pode ser considerado um fracasso, foi a de não se ter compreendido essa condição inerente à disciplinaridade: os professores não podem, de forma unilateral e voluntária, deixar de ministrar e avaliar o conteúdo específico da disciplina em que estão alocados. Ou, em outras palavras, as disciplinas não conseguem, por principio, articular os seus conteúdos ao conteúdo de um trabalho dito "integrado".

36 Regimento Geral da USP, ART. 66: "A unidade do ensino é a disciplina". 


\subsection{A reestruturação do Departamento de Projeto / 1977}

Como foi visto, a estrutura curricular aprovada nos desdobramentos do chamado "Fórum de 78" e implantada em 1980, tinha como objetivo a integração das disciplinas, ou a interdisciplinaridade, para superar da fragmentação do conhecimento e do ensino instalada na FAUUSP e que teria distanciado a formação do futuro arquiteto da realidade profissional e social em que iriam atuar. No entanto, o que ocorreu, de fato, foi o aprofundamento do problema que a reforma se dispôs a superar.

Apesar da gravidade da situação, a FAUUSP não conseguiu implementar nenhuma medida eficaz para sua solução por quase duas décadas. As assembléias plenárias convocadas em 1986, por exemplo, pouco contribuiu para melhorar a situação do ensino. Apenas duas propostas então aprovadas viriam a ser implementadas, mas somente uma década depois pelo Departamento de Projeto: a criação do "Curso introdutório" integrado para os alunos ingressantes e a redução do TGI de dois para um semestre.

Foi o Departamento de Projeto que deu início à tentativa de reversão da situação, porque era nesse departamento que o problema havia se instalado de forma mais aguda, exatamente porque era onde a reforma havia sido implantada integralmente. Mesmo assim não o fez senão em 1992 grandemente instado pela decisão tomada no ano anterior pela Comissão de Graduação ${ }^{37}$ - criada em 1989 pelo novo estatuto da USP _ , que determinava, basicamente, a redução do número de disciplinas da escola em pelo menos $25 \%$, como parte do esforço para superar a atomização da estrutura curricular.

37 À Comissão de Graduação "cabe traçar diretrizes e zelar pela execução dos programas determinados pela estrutura curricular [...]" (Estatuto da USP, Artigo 48). 
Após cinco anos de desgastante mas aprofundado processo de análises e discussões em seminários, comissões e grupos de trabalho e no próprio Conselho do Departamento ${ }^{38}$, foi aprovada a proposta de reestruturação que seria implantada parcialmente em 1998 e integralmente no ano seguinte.

Como não podia deixar de ser, o problema mais imediato a ser enfrentado era, novamente, a fragmentação generalizada, determinada pela compartimentalização e estanqueidade estruturais tanto das disciplinas quanto das atividades ditas "acadêmicas" - isto é, o ensino, a pesquisa e a extensão de serviços à sociedade -, aprofundada pela multiplicação de disciplinas resultante das decisões do Fórum de 78.

Para agravar ainda mais esse quadro, ao longo desse período ocorreu uma deterioração gradativa da proporção aluno/professor, causada pela falta de reposição de docentes determinada por diversos fatores. Criouse, então, uma condição insustentável, em que a média dessa relação chegou, em aulas praticas de ateliê, a 45 alunos para cada professor, com casos que chegaram a mais de 60 para 1, configurando uma situação cuja impraticabilidade ficava ainda mais evidente se for considerado o critério adotado pelo próprio Departamento de Projeto para a definição das turmas em suas disciplinas optativas - de funcionamento similar às demais -, em torno de 15 alunos por professor.

O ponto de partida para a concepção da reestruturação foi a definição conjunta de algumas premissas e diretrizes que orientaram as discussões do encaminhamento dos problemas, e sobre as quais não havia maiores dissensões: a) reafirmação da arquitetura como o eixo condutor das atividade s do Departamento de Projeto; b) a necessidade de

\footnotetext{
${ }^{38} \mathrm{O}$ conselho do departamento é o "órgão deliberativo em assuntos de administração, ensino, pesquisa e extensão universitária" (Estatuto da USP, Artigo 54); o departamento "é a menor fração da estrutura universitária para os efeitos de organização didático-científica e administrativa” (Ibidem, Artigo 51).
} 
racionalização dos recursos acadêmicos; c) aproximação à realidade prática da profissão.

\subsubsection{Reafirmação da arquitetura}

A reestruturação deveria enfatizar, como conteúdo central do Departamento de Projeto, a edificação e a cidade ${ }^{39}$, ao mesmo tempo como uma atividade concreta de produção, nos termos enunciados pela proposta aprovada.

"A arquitetura, entendida como demanda contemporânea de espaço construído, em sua dimensão econômica, social, cultural, política e ambiental.

O urbanismo, como coordenação política e instrumental planejada das aglomerações urbanas e do território sob sua influência". (FAUUSP-d, p.3)

Para tanto, foi decidido, por um lado, que a participação desse conteúdo seria ampliada na carga horária das atividades do ateliê e, por outro, que se manteria o objetivo de "integração do conhecimento" (Ibidem, loc.cit.).

Como resultado, o total de horas de atividades-aula dedicadas a todas as disciplinas obrigatórias de projeto de edificações e de planejamento urbano somadas a todas as suas optativas, teve um aumento de $33,33 \%$. Essa porcentagem se manteria em $25 \%$ mesmo em casos em que o aluno não cursasse nenhuma das optativas com esses temas. A

\footnotetext{
${ }^{39}$ Apesar de todo o currículo do Departamento ter sido organizado visando a formação do arquiteto, nem sempre seus conteúdos foram interpretados corretamente. Mesmo professores do próprio departamento muitas vezes têm dificuldade de entender o papel das outras disciplinas que não a sua, especialmente aquelas que se definem por meio de conceitos não consensuais, como "desenho industrial", "paisagismo" e, especialmente "programação visual". Esse equívoco tende a se ampliar no âmbito externo da escola, como revela o injusto comentário de que FAUUSP "forma até arquiteto". A propósito, consultas informais feitas pelo autor com alunos ingressantes, nos meados da década de noventa, revelaram em certos casos que até em torno de metade da turma declaravam que a opção pela FAUUSP havia sido tomada para se formarem "designers" gráficos.
} 
participação desses conteúdos no total de horas de atividade-aula do Departamento passou a ser de $70 \%$ (contra os $51,21 \%$ anteriores, representando um incremento percentual de $36,69 \%$ ) se somadas todas as obrigatórias e todas as optativas. Ainda que estas fossem excluídas, o percentual se manteria em $50 \%$ (contra $39,02 \%$ anteriores, um aumento de $28,13 \%)$.

Em paralelo a essas medidas, o projeto de reestruturação procurou desenvolver esses conteúdos em gradações de complexidade e "de modo crescentemente convergente, na busca de integração do conhecimento, consideradas as várias escalas de atuação do arquiteto, centradas na arquitetura e urbanismo" (Ibidem, loc.cit.).

Esses objetivos seriam alcançados por meio de uma estrutura organizada em segmentos seqüenciados considerados adequados para implementar essa gradação. Foram criados quatro "ciclos" que compunham duas seqüências maiores: uma, inicial, com caráter de introdução à arquitetura e de apropriação da habilidade de projetação, denominada "Ciclo Básico" e a outra, de exercitação de projeto, dividida em três etapas, "Ciclo de concentração", "Ciclo de projetos" e "Ciclo final".

"Ciclo básico"

A fase inicial, de cinco semestres, foi denominada "Ciclo básico" e se compõe de um semestre de introdução aos fundamentos de arquitetura (sempre no sentido de "arquitetura e urbanismo", conforme Artigas), seguido de uma fase de transmissão de conhecimentos básicos e de exercitação de habilidades de projeto, sempre incluindo a articulação dos aspectos práticos e teóricos em trabalho em ateliê. Neste ciclo as disciplinas têm como objetivo preparar os alunos para os ciclos seguintes e por essa razão, elas são de caráter obrigatório. 
O primeiro desses cinco semestres - "Fundamentos de projeto" - é constituído de uma única disciplina e seu conteúdo é elaborado e ministrado por uma equipe de professores dos cinco grupos de disciplinas do departamento. Dispõe de quatro aulas por semana e mais uma tarde livre para atividades de apoio. Já nos outros semestres, os grupos de disciplinas desenvolvem seus conteúdos específicos em uma ou duas tardes por semana (dois dos cinco grupos com duas aulas, um com uma aula em revezamento semestral), mas com todos os grupos dispondo da mesma carga horária ao fim desses quatro semestres e assegurada a seqüencialidade semestral para as disciplinas de arquitetura - edificações e cidade.

"Ciclo de concentração"

Iniciando a seqüência dedicada à exercitação do projeto, após a conclusão da fase de preparação, este ciclo foi concebido em função de uma possibilidade inovadora de relativização da compartimentalização disciplinar tradicional ${ }^{40}$.

\footnotetext{
${ }^{40} \mathrm{Na}$ realidade, havia inicialmente uma quase unanimidade com relação ao caráter de opcionalidade de toda a segunda fase do curso, que compreendia os quatro semestres após o Ciclo básico, tanto que essa fase era chamada "Ciclo de projetos". Na concepão original deste Ciclo de projetos as atividades de exercitação de projeto - a razão e finalidade maior da existência do Departamento - seria organizada não mais pelos grupos de disciplinas mas pelos professores com a participação dos alunos com o princípio de livre associação e livre proposição, com a única condição de que um mínimo de 50\% das temáticas ministradas fossem de arquitetura, isto é, que versassem sobre edificações e/ou cidade. Entretanto, o Grupo de Discplinas de Projeto de Edificações exigiu o controle disciplinar sobre a sua parte nesta reserva temática. A exigência, colocada de forma incondicional, teve que ser acatada para evitar que fossem anulados os outros avanços que haviam sido conquistados duramente ao longo de cinco anos. Naturalmente, a inevitável cessão a essa imposição unilateral abriu caminha para que igual exigência por parte do Grupo de Disciplinas de Planejamento fosse também incluída na proposta, na forma das disciplinas de "concentração" de Projeto de Edificações e de Planejamento, com a metade da carga horária total do ciclo que seria de projetos não disciplinares.
} 
Mesmo que ainda tenham sido programados como disciplinas obrigatórias desenvolvendo conteúdos diferentes, neste ciclo devem ser elaborados projetos integrais, ao contrário dos trabalhos com abordagens parcelares das disciplinas dos 4 semestres do Ciclo básico. Não se trata mais, então, de "integrar" conteúdos pré-estabelecidos, mas sim de organizar os conhecimentos a partir do tema trabalhado, e para isso é recomendada a associação e mobilização dos professores os mais preparados segundo o problema escolhido, independentemente da disciplina em que estão formalmente alocados.

“[...] será estimulada a formação de grupos de professores de várias àreas, para ministrar o mesmo curso, para que tenham maior oportunidade de intercâmbio de conhecimento entre si, criando-se mais um mecanismo integrativo e portanto tornando mais simples a tarefa de integração do aluno." (Ibidem, p.4)

Ciclo de projetos

O objetivo deste ciclo é de exercitar a atividade de projetação por meio de problemas a serem livremente escolhidos pelos alunos a partir de um elenco de opções previamente estabelecidas versando, naturalmente, sobre conteúdos afins à arquitetura. Cabe observar que a oferta das disciplinas, caracterizada agora como "optativas" será de responsabilidade mais dos professores do que dos grupos de disciplinas ou mesmo do departamento, , pois deverá haver, neste ciclo

"ainda maior estímulo que no de Concentração, para a formação de grupos interdisciplinares de professores, até de outros departamentos da FAU e mesmo de outras unidades de ensino e pesquisa da USP, na ministração de seus cursos." (Ibidem, p.5)

Ciclo final 
Na nova estrutura, o já tradicional trabalho de graduação, agora TFG Trabalho Final de Graduação passou a ser desenvolvido em apenas um semestre em vez de dois, como era praxe desde sua criação em 1968. Essa medida foi incorporada à proposta em observância à decisão que havia sudi tomada na assembléia plenária da escola realizada em 1986. Entretanto, havia consenso de que o tempo previsto era insuficiente e 0 Conselho do Departamento aprovou posteriormente uma proposta conciliadora que possibilitava ao aluno optar por iniciar os trabalhos a partir do oitavo semestre, sem prejuízo da matrícula e freqüência no TFG do décimo semestre.

\subsubsection{Racionalização de recursos}

Para fazer frente à pulverização do conhecimento a transmitir, e as suas conseqüências, como o excesso de superposições de conteúdos, a sobrecarga de trabalho tanto de professores quanto de alunos e o desperdício de recursos de toda sorte - acadêmicos, pessoais, físicos e materiais -, a reestruturação efetivou uma drástica redução do número de disciplinas mantendo, no entanto, a carga horária total do Departamento de Projeto (na realidade, houve uma pequena redução de $2,43 \%$ ).

As 41 disciplinas herdadas do Fórum de 78 foram substituídas por 21 (redução de $48,78 \%$ ), não inclusas aí as duas disciplinas que constituíam anteriormente o TGI, que passou a ser apenas um depois da mudança; as 36 disciplinas obrigatórias passaram a ser 17 (redução de 52,77\%); as 5 optativa passaram a 4 (redução de $20 \%$ ).

Assim, foi reduzido de forma significativa o número tanto das disciplinas quanto o de seus respectivos trabalhos. Após a reestruturação, os alunos passaram a desenvolver, concomitantemente, apenas um trabalho no primeiro semestre, três nos quatro seguintes e dois no oitavo e no nono semestres. Além disso, dispunham, agora, de mais tempo para elaborar 
seus trabalhos, pois as disciplinas tiveram suas cargas horárias praticamente dobradas.

Em média, houve uma redução de 5,12 disciplinas por semestre para 2,33 $(54,47 \%)$, mas mantendo a carga didática total do curso em $2.880 \mathrm{~h}$, entre créditos-aula e de trabalho. Com esses novos números, também melhorou a proporção média aluno/professor, da anterior, de 45 alunos para 1 professor - 45:1 - a em alguns casos, que chegava a até mais de 60:1 para 35:1, com redução de 22,22\% e 41,66\% respectivamente, relação ainda extremamente alta.

Não se pode desprezar também, ainda que num plano complementar que fato de que, com menos disciplinas ocorreu a racionalização de recursos em geral -desde físico e mateirais a humanos e financeiros.

\subsubsection{Aproximação à realidade}

A possibilidade de se propor trabalhos sem a limitação de caráter disciplinar, aberta pelo expresso apoio manifestado à livre associação de professores - de forma mais restrita já no ciclo de concentração mas, de forma extensiva no ciclo de projetos, ou seja nas "disciplinas" optativas abre, de forma inédita, a perspectiva para a elaboração de projetos que lidassem com problemas reais da sociedade. Nessas condições, tais problemas induziriam o aluno a uma motivação e um comprometimento muito maiores para com o trabalho de ateliê e, ao mesmo tempo, referenciariam a organização da mobilização ou até a produção dos conhecimentos necessários para a sua solução. Essa forma de trabalho, que contrastava com a abordagem anterior, na qual era o conteúdo das disciplinas que determinavam tanto a escolha quanto o tipo de solução dos problemas, reproduziria, de certa maneira, as condições reais do trabalho do arquiteto e aproximando, portanto, o aluno da realidade prática da profissão. 


\subsection{Conclusão do capítulo}

Da análise desses momentos mais significativos do processo de reformulações do ensino da FAUUSP pode-se extrair algumas conclusões aplicáveis à questão do ensino da arquitetura em geral.

A reforma como necessidade do processo

Em primeiro lugar, confirma-se a observação de Cintra do Prado sobre a vocação crítica da FAUUSP e sobre a necessidade intrínseca de continuadas revisões de seu ensino, que mantém estreita interação com a profissão. Nesse sentido, a critica e as ações reformadoras que ela permite instaurar constituem, mais que uma constante, uma condição vital para a existência não só das escolas, mas da própria profissão. Tanto é que a própria institucionalização do ensino independente de arquitetura, na década de quarenta, foi o resultado da reivindicação da categoria então em ascensão, impulsionada pelas novas condições desenvolvidas pela expansão econômica do pais. Entretanto, apesar das fortes pressões externas sofridas através da profissão, o ensino profissional comporta questões específicas que podem e só podem ser resolvidas no âmbito interno. É nesse contexto que as reformulações do processo focalizado foram empreendidas e é a partir dessa perspectiva que devem ser entendidas.

O "ensino de arquitetura" como "ensino de projeto"

Uma evidência que emerge desse processo é que as "reformulações mais significativas do ensino de arquitetura" dizem respeito ao "ensino" de projeto, atividade central, embora não exclusiva, da arquitetura. 
Resumindo, os problemas de "ensino de arquitetura" são, fundamentalmente, problemas do ensino de projeto.

Com efeito, uma das reivindicações do intenso movimento da categoria na década de cinqüenta no que se referia ao ensino profissional era a reorganização do ateliê, reiteradamente promovido como espaço por excelência de formação de um projetista.

A ineficácia das reformulações

Outra constatação é que, apesar do vigor da postura crítica e o sem número de reformulações que ela conseguiu propor e implantar por todo o país, alguns importantes problemas do ensino de arquitetura continuam sem solução satisfatória, condição que pode ser confirmada pela persistência das queixas sobre o desempenho das escolas de arquitetura e a manutenção desse processo de revisões sucessivas nas escolas dos mais diferentes lugares e matizes, públicas, confessionais, particulares.

No exemplo da FAUUSP confirma-se que alguns problemas foram equacionados e outros não. Foi visto que a tentativa de resolver um problema pode até gerar outros ou até agravar o que se tentou solucionar; a solução de hoje poderá ser o problema de amanhã. E é, a partir dessas experiências da FAUUSP - bem sucedidas ou não - que podem ser destacadas algumas propostas que parecem constituir importante fonte para a reflexão sobre o ensino de arquitetura ou, o ensino de projeto: o resgate e a valorização do ateliê de 1962 e seu desgaste paulatino, a formatação da tese de graduação em 1968 e a reconceituação das disciplinas optativas em 1997. 
O ateliê e a disciplina 


\section{1 $O$ ateliê da FAUUSP}

O ateliê revigorado e reorganizado, um dos objetivos maiores da mobilização dos arquitetos e estudantes na década de cinqüenta e viabilizada pioneiramente na FAUUPS pela Reforma de 62, sofreu um processo de desgaste gradativo que acabou por frustrar o entusiasmo inicial passando até a ser alvo de intensas criticas e ser responsabilizado pela alienação do estudante em relação ao mundo real da profissão e da própria sociedade.

Pode-se dizer que esse processo de degradação tenha se iniciado no momento mesmo de sua implantação, quando a atividade de projetação, para a qual foi concebida, sofreu uma divisão artificial e foi distribuída pelas quatro "linhas de tarefas ou estudos" (PRADO, p.9), mais tarde caracterizadas como "áreas" do departamento de "projeto", ou grupos de disciplinas, que compartilhavam a organização dos trabalhos do Departamento de Projeto mas, de fato, mantinham e funcionavam com conteúdos específicos.

Inicialmente, essa divisão não indicava uma fragmentação do conjunto do conteúdo curricular ou da estratégia didática, na medida em que o aluno era avaliado no conjunto das disciplinas organizadas com periodicidade anual. Entretanto, com a implantação da Reforma Universitária e o seu sistema de créditos, tanto a matrícula quanto a avaliação - e, portanto, a aprovação -, passaram a ser efetuadas por disciplinas, das quais, algumas podiam ser optativas.

Essa nova organização do ensino dividiu e transferiu para as disciplinas o antigo poder acadêmico concentrado nas cátedras, por sinal abolidas pela mesma reforma. Como a nova legislação universalizou o acesso a esses novos nichos do poder, dispensando quaisquer ritos como aqueles que 
regiam os concursos para as cátedras, todos os professores passaram a deter os fragmentos desse poder assim que eram alocados nas disciplinas, independentemente de sua competência ou titulação acadêmicas.

Por outro lado, como não havia restrições para a criação de novas disciplinas, a nova estrutura universitária trazia no seu cerne a possibilidade de multiplicação desses pequenos nichos de poder para delimitar e proteger os territórios do conhecimento, cada vez mais especializado.

Fosse por essa razão ou por outra, mas certamente pela semestralização da grade curricular, também determinada pela Reforma Universitária, o fato é que o número de disciplinas se multiplicou até se atingir uma situação, percebida e criticada, como sendo de atomização do ensino em geral e, em particular, na FAUUSP. Realmente, a necessidade de acomodar esse grande número de disciplinas pelas etapas semestrais do curso provocou, muitas vezes, a convivência de conteúdos sem relação de continuidade entre si, deixando evidente a fragmentação do ensino.

Para os alunos, essa sensação era reforçada pela ausência de um critério maior na composição de seus conteúdos semestrais, seja por força de aprovações ou reprovações processadas isoladamente, seja pela dificuldade em exercer a opção preconizada naquelas disciplinas que, formalmente, deveriam ser de livre escolha: as optativas.

Além disso, na FAUUSP em particular, e nas escolas que reproduziram o seu currículo, esse processo foi exacerbado pela inclusão de conteúdos inéditos e, aparentemente estranhos à arquitetura: o desenho industrial e a comunicação visual. Provavelmente, esse estranhamento foi reforçado pela transposição equivocada de uma determinada imagem da profissão, influenciada pelo destaque alcançado por alguns arquitetos que se dedicavam principalmente a atividades consideradas afins daquelas disciplinas - como o projeto de produtos gráficos -, mas que não compartilhavam o objeto por excelência da arquitetura, o espaço. 
Não se discute aqui o direito do arquiteto em atuar em atividades diversas àquela de sua atribuição específica, mas o que se coloca é o efeito reverso que as opções em outros campos profissionais provoca na organização do ensino do futuro arquiteto.

Com efeito, é fácil verificar que, até para muitos professores da FAUUSP, a comunicação visual por exemplo, hoje conhecida como "programação visual", é considerada competência diferente da arquitetura mas, ao mesmo tempo, uma de suas "áreas" profissionais. Esse entendimento se estende, ainda que mais moderadamente, ao desenho industrial.

Dessa maneira, não é de se estranhar que essas disciplinas fossem percebidas como uma primeira fragmentação do conteúdo da arquitetura e da atividade de projeto ministrado pelo Departamento de Projeto, ainda que elas estivessem mantendo e ainda mantêm um imprescindível papel em razão pela qual foram inseridas na sua grade: o trato das questões da visualidade do espaço e da produção e dos processos de industrialização. ${ }^{41}$

O que essa ambigüidade, envolvendo tais disciplinas revela, é a inexistência de um projeto acadêmico claramente estabelecido ou, pelo menos discutido, no Departamento de Projeto e na FAUUSP, fato que caracteriza uma crise de identidade que pode estar comprometendo o seu potencial de formação profissional mais conseqüente.

Como foi visto, a Reforma de 78 agravou o problema da pulverização do ensino da FAUUSP. Esse fracasso pode ser atribuído a algumas incompreensões que envolveram a discussão, a elaboração, a aprovação e a implantação daquela proposta, especialmente no que se refere à forma disciplinar da estrutura de ensino da escola, baseada no princípio da segmentação dos conteúdos. Sem uma correta compreensão dessa

${ }^{41}$ Ver nota 41, em "Reestruturação proposta". 
característica intrínseca da disciplinaridade, decidiu-se pela estratégia da integração das disciplinas, caracterizando um claro equívoco conceitual que afrontava o princípio com que estas se organizam. O resultado foi que a maioria das disciplinas acabou por não abrir mão de seus conteúdos quando da implantação da integração.

Pode-se dizer que esse equívoco, bem como outras incompreensões têm levado à repetição desgastante de experiências, que apenas tangenciam os problemas mais decisivos, gerando uma reação de descrença e apatia com relação aos problemas do ensino, Assim, foram-se mantendo ou retomando os procedimentos antigos que foram, exatamente, a origem dos problemas que se pretendeu solucionar. Essa situação se prolongou por quase duas décadas e, certamente, prejudicou seriamente os arquitetos que a FAUUSP formou nesse período.

É importante observar que essa "incompreensão" conceitual não se limita à questão da disciplinaridade. A própria idéia de ateliê, por exemplo, concebida acertadamente pelos movimentos de sua reivindicação e na sua implantação, foi se perdendo na rotina estabelecida nessas poucas décadas de existência.

Para concluir essas considerações, parece patente que esse equívoco de fundo que frustrou a Reforma de 78 se repete, em maior ou menor grau, em outras experiências de reformulação do ensino de arquitetura, tanto da própria escola quanto das demais. 


\subsection{Tese de graduação}

Ao contrário da proposta do ateliê, o trabalho de conclusão do curso, ou "Tese de graduação", implantada em 1968, até como iniciativa isolada dos responsáveis por essa disciplina, teve ampla aceitação e construiu um exemplo da forma de trabalho de ateliê possível para uma desejável exercitação da atividade projetual.

A transformação do trabalho do último ano do ateliê em tese de graduação, ou seja, um trabalho desenvolvido a partir da livre escolha do problema pelo aluno, devidamente acompanhado pelo professor orientador, representou a liberação do aprendizado de projeto dos limites impostos pelo método disciplinar e uma aproximação maior à realidade e à prática profissional.

Ao invés do que havia sido obrigado a fazer nos quatro anos anteriores do curso, produzindo respostas a problemas previamente formulados pelas disciplinas, pela primeira vez no curso, ao aluno é concedido, ao menos em tese, a liberdade e a total responsabilidade de assumir e formular um problema.

Abria-se, assim, a real possibilidade para o aluno construir sua autonomia intelectual, através da exercitação da responsabilidade de assumir um problema e construí-lo, dimensões tão ou mais importantes que a sua solução, se for aceito que os problemas em arquitetura envolvem uma complexidade tal que neutraliza qualquer abordagem por meio de modelos de soluções para problemas também formulados como modelos. É por essa forma de organização curricular-didática que a tese de graduação suscitou o comprovado e sempre revitalizado interesse dos alunos e consolidou-se como um importante referencial, ainda pouco reconhecido, para a reflexão sobre o ensino de projeto como um todo. 


\subsection{Optativas de 97}

As optativas de 1997 faziam parte da proposta de reestruturação que visou a superação dos problemas agravados pelo Fórum de 78. Apesar de não ter conseguido objetivar as razões desse agravamento e tampouco os fundamentos da proposta de sua superação, inovou ao criar uma estrutura que abria possibilidades promissoras para a melhoria do ensino de projeto no ateliê.

Em primeiro lugar pressentiu-se que o curso deveria ser dividido segundo duas necessidades didáticas básicas do ensino de projeto. Um ciclo inicial, que corresponderia á introdução e à preparação do aluno para as atividades do ateliê propriamente dito, compreendendo os conhecimentos e habilidades básicos para o projeto. As atividades deste ciclo seriam organizadas através de disciplinas obrigatórias, preparadas e ministradas pelos grupos de disciplinas.

Em seguida, com a preparação adquirida no ciclo inicial, o aluno aprofundaria a exercitação da atividade de projetação, de preferência trabalhando em problemas reais por meio de "disciplinas optativas", agora totalmente reformuladas em relação às homônimas anteriores à reestruturação.

Essas novas optativas haviam recebido um aumento substancial de carga horária (100\% em cada uma e $60 \%$ no conjunto) e passaram a ser organizadas e oferecidas tendo como princípios a livre associação de professores, inclusive vindos de outras escolas, e a livre proposição de problemas. Estes não mais seriam formulados de maneira setorizada e, portanto, abstrata nos limites dos conteúdos parcelares e preestabelecidos dos grupos de disciplinas. A única condição era que o conteúdo de duas das quatro optativas que o aluno deveria cursar, 
fossem relativos a edificações e à cidade. Pode-se afirmar que, o que essa proposta autorizava e assegurava era o resgate da liberdade como valor que deve fundamentar o fazer acadêmico tanto em termos das pesquisas docentes quanto em termos da formação de uma autonomia intelectual por parte dos futuros formandos e, ainda, como um dos objetivos maiores da universidade.

Se a proposta fosse efetivamente viabilizada, certamente sua prática poderia abrir algumas outras perspectivas nela implícitas: uma possibilidade seria a proposição organizada de temas por iniciativas dos alunos, individualmente ou através de seus órgãos extra-curriculares como os escritórios-modelo ou empresas-júnior.

Outra perspectiva promissora configurada pelas novas optativas seria a articulação sistemática do ensino com as atividades de pesquisa e de prestação de serviços ou, inversamente, a proposição e a condução dos trabalhos de ateliê por outras instâncias acadêmicas, tais como laboratórios, e não exclusivamente pelas disciplinas.

Cabe observar que, nestes casos se conseguiria aproximar as atividades das optativas e das pesquisas dos professores e, assim, mobilizar a infraestrutura de pesquisa da instituição como apoio às atividades de ensino, o que propiciaria condições mais adequadas para incorporar ao trabalho do ateliê, problemas concretos de interesse social e acadêmico e cumprir a expectativa de aproximação entre a formação profissional e a realidade em que o aluno virá a se inserir.

Além disso, os trabalhos do ateliê, assim organizados, poderiam estabelecer de forma natural e clara, os procedimentos para a necessária aferição do aprendizado tanto dos alunos quanto do desempenho didático dos docentes. Os alunos conseguiriam acompanhar seu desenvolvimento por meio da resposta dada pela sociedade para seus projetos; os professores, por sua vez, poderiam conferir o seu desempenho didático e 
a validade de sua proposta através do grau de adesão dos alunos à sua optativa.

Desse modo, o aluno, ao mesmo tempo, aprenderia, pesquisaria e prestaria serviço à sociedade, realizando em uma única experiência a integração das atividades acadêmicas tradicionalmente fragmentadas, o que em uma atividade de síntese como o projeto comparece até como uma pré-condição, mas que não era reproduzida na escola. Viabilizar essa experiência no ensino foi o sentido em que a proposta das optativas de 97 constituiu uma inovação. Oferecia-se, assim, ao aluno, a perspectiva de construir uma experiência muito próxima da prática profissional e muito mais que isso, a autonomia que lhe permite lidar com a realidade dinâmica do campo profissional.

Na essência, o que as novas optativas possibilitavam e ainda possibilitam não era a integração entre disciplinas como a reforma anterior havia pretendido, mas a mobilização e a efetiva integração dos conhecimentos que fossem necessários para a solução de um determinado problema, independentemente das disciplinas depositárias de tais conhecimentos, o que só é possível a partir da correta compreensão do problema assumido.

Portanto, não se tratava mais de tentar, inutilmente, enquadrar a questão, real ou idealmente construída, aos limites da disciplina, mas o inverso, ou seja, formular e construir o problema com base na busca e na rearticulação dos conhecimentos disponíveis e produzindo aqueles que faltavam. Nesse sentido, esses espaços da grade curricular-didática não eram mais pensados em termos de "disciplinas", tanto que durante o processo de discussão da proposta de reestruturação, eram denominados muitas vezes como "ateliês de projeto".

A propósito, é interessante registrar que essa significativa mudança no conceito de organização do ateliê, expressamente estabelecido na proposta oficial de reestruturação, de certa forma incorporou a já larga e 
bem sucedida experiência das teses de graduação, apenas restringindo a liberdade de escolha dos problemas por parte dos alunos.

A proposição dessas optativas, que podem ser consideradas, em tese, a contribuição mais importante da reestruturação de 97 , só foi possível pelo correto posicionamento - ainda que não tenha sido de forma objetivada e explicitada - com relação à disciplinaridade da organização do ensino de projeto arquitetura.

Reconheceu, de uma parte, sua importância enquanto instrumento privilegiado para as imprescindíveis atividades de transmissão e produção do conhecimento, bem como de treinamento de habilidades específicas preparatórias e incorporou-a no Ciclo básico. De outra parte, descartou-a por sua incompatibilidade para com as atividades de exercitação de habilidades de projetação, ou seja, demonstrou sua ineficiência na aplicação daqueles conhecimentos e habilidades adquiridos pelo método disciplinar, e introduziu uma outra forma, não disciplinar, de organização das atividades do Ciclo de concentração e do Ciclo de projetos.

É possível avaliar o potencial das "optativas de 97" pela experiência de algumas delas, que conseguiram resultados considerados bastante expressivos. Embora não se possa, em caráter definitivo, avaliar exatamente qual tenha sido a parcela de contribuição real da reestruturação para o seu sucesso, até porque elas já tinham alguma experiência similar na estrutura anterior, pode-se certamente afirmar que foram beneficiadas com a duplicação da carga horária determinada por essa reestruturação.

Vale citar que, duas dessas "disciplinas" foram oferecidas por professores de planejamento. Uma assumiu o problema dos loteamentos irregulares articulado com a questão da sustentabilidade ambiental (ver abaixo), outra o problema dos cortiços na área central da capital paulista. Mais recentemente outra optativa, conduzida por professores de paisagismo, 
desenvolveu um projeto em área de um assentamento do Movimento dos Sem Terra localizado na Região Metropolitana de São Paulo.

Nos três exemplos, portanto, foram assumidas questões distantes do conceito tradicional de arquitetura, mas intervieram em uma realidade em processo, nem sempre com um resultado material palpável e imediato, mas sem dúvida através de uma forma imprescindível de atuação para a organização do espaço e do ambiente humanos, ao fim e ao cabo o objetivo maior da arquitetura.

O primeiro dos exemplos foi a optativa "AUP 0547 - Ambiente Construído e Desenvolvimento Sustentável - Moradia Social" e teve como responsáveis as professoras Ermínia Maricato e Maria Lúcia Refinetti Martins que propunham como tema o equacionamento do problema da habitação de interesse social em articulação com situações reais envolvendo relações conflituosas com o meio ambiente.

O objeto de trabalho específico, focado por essa optativa em 2002 e em 2003, foi um loteamento irregular localizado no município de Diadema, próximo às margens da Represa de Billings. Esse loteamento era um exemplo paradigmático inserido no contexto do problema de ocupação generalizada e ilegal da área dos mananciais da região metropolitana de São Paulo.

Por envolver uma população de mais de um milhão de habitantes, não era socialmente viável a aplicação automática da legislação que permite e obriga a desocupação da área. Este impasse levou o Ministério Público a buscar parceria com o Labhab - Laboratório de Habitação Popular, coordenado na época pela Profa Ermínia, para estudar propostas integradas para o equacionamento do problema.

A solicitação foi incorporada na programação do Labhab que, além de um convênio de pesquisa já em andamento com uma universidade estrangeira sobre a questão, mantinha parcerias em várias frentes, 
inclusive com a Prefeitura do Município de Diadema, diretamente interessada na pesquisa em em curso.

O Labhab incorporou as atividades da referida optativa como parte do convênio. Como apoio à disciplina, foi colocada à disposição dos alunos a infraestrutura do Labhab: dados da pesquisa, apoio para a organização de seminários, palestras a serem proferidas por professores, especialistas de diversas áreas, como urbanistas, juristas, promotores, técnicos das prefeituras e órgãos públicos, etc.

Além dessas atividades, foram programadas e realizadas aquelas de rotina de uma disciplina tradicional, como aulas teóricas, visita ao local, pesquisas de campo, levantamentos iconográficos e bibliográficos, processamento de dados levantados, produção de materiais de base como mapas, trabalhos propositivos em ateliê, seminários.

O aproveitamento dos alunos ao final do curso pode ser avaliado tanto pelas propostas que, de alguma maneira, contribuíram para a pesquisa do Labhab, quanto pelo nível de familiarização dos alunos com a questão trabalhada.

Muitos dos alunos continuaram o trabalho iniciado na optativa como estagiários e, depois, pesquisadores do Labhab, bem como em empresas e órgãos públicos envolvidos com questões afins. Não poucos alunos também foram requisitados pelas prefeituras da região dos mananciais como estagiários e, às vezes, até para assumirem responsabilidades não usuais para estagiários, tendo inclusive uma dessas ex-alunas da disciplina, oficialmente apenas uma estagiária, sido designada por uma Secretária Municipal para substituí-la numa palestra de apresentação do projeto de plano diretor do município na FAUUSP.

É importante reiterar que o trabalho com uma problemática concreta, em estreito contato com a realidade e comprometido com a produção de resultados que possam contribuir para uma pesquisa institucional foi. e 
sempre, será a fonte da motivação e do empenho dos alunos e condição para um aprendizado mais maduro e responsável por parte do futuro profissional. Além disso, o caráter eminentemente social do problema trabalhado certamente foi um incentivo para a adesão significativa dos alunos à optativa e para sua conscientização com relação às possibilidades de uma ação social na prática da arquitetura.

Esses exemplos comprovam que a reestruturação oferecia a real possibilidade de equacionar os problemas que procurou resolver. Entretanto, deve se reconhecer que tais possibilidades foram escassamente exploradas e a maioria das optativas continuou a ser programada e ministrada de forma tradicional, como disciplinas especializadas em conteúdos abstratos. 


\subsection{A questão}

Uma evidência que se configura na análise desses casos, é que os fenômenos da degradação do ateliê, do sucesso da tese de graduação e da indiferença para com as optativas reconceituadas, foram determinados diretamente pelo tipo de relação que cada experiência estabeleceu com a estrutura didática em que foi inserida.

Na medida em que essa estrutura se organiza disciplinarmente, emerge como dimensão decisiva do ensino de arquitetura o paradigma da disciplinaridade que a justifica e a sustenta.

Por outro lado, a constatação de que tais relações nunca foram explicitadas sistematicamente ao longo de todo o processo em que se destacaram os exemplos analisado, direciona, naturalmente, a conclusão das reflexões desenvolvidas para a questão da disciplinaridade. 
5 Disciplinaridade ou o poder disciplinar 


\subsection{O poder disciplinar}

A universidade moderna foi criada na passagem do século XVIII para XIX para promover o "desenvolvimento máximo da ciência". Para tanto, Humboldt, concebeu para as "Instituições Científicas Superiores" em Berlim, conhecida como Universidade de Berlim, uma estrutura baseada em "departamento" 42 , uma instância organizacional destinada a "produzir e preservar uma colaboração contínua entre cientistas de diferentes disciplinas", porque acreditava que a atividade intelectual "somente progride quando há cooperação". A idéia era de que "um investigador forneça o que falta ao outro" mas também que o "êxito de sua atividade entusiasme o outro".

Uma característica marcante da proposta de Humboldt era que a universidade e seus departamentos deveriam ser instituições necessariamente estáveis e perenes porque, em primeiro lugar, a pesquisa seria infinita ("a ciência é [...] um problema que nunca pode ser totalmente resolvido", "uma eterna busca") e também porque deveriam ser assegurados os princípios de autonomia e liberdade, imprescindíveis para se realizar "a idéia pura" da ciência.

Por outro lado, para Humboldt, a universidade deveria ser independente mas, ao mesmo tempo, ser mantida pelo Estado, pelo evidente interesse e benefício que para este representaria o bom desempenho daquela.

Com essa concepção, a Universidade de Berlim se tornou, desde sua criação em 1810, o modelo por excelência das instituições de pesquisa e ensino superiores. Tanto quanto sua estrutura de departamentos, a

\footnotetext{
42 O departamento seria uma re-elaboração da instituição medieval "faculdade", que se referia, igualmente, "a uma capacidade, a um ramo de conhecimento e a um grupo corporativo" (BURKE, p.86-87).
} 
própria forma de organização do conhecimento através das "disciplinas científicas" se universalizou e, em apenas dois séculos, todo "o conhecimento assumiu a forma disciplinar" num grau tal que hoje é até "difícil imaginar alguma outra forma em que se possa produzir e organizar o conhecimento". (MESSER-DAVIDOW, SHUMWY e SYLVN, p.vii).

Para esses autores, o poder dessa forma de organização é muito mais determinante: hoje estaríamos sendo "socialmente e conceitualmente disciplinado" pelas disciplinas:

Elas ajudam a produzir nosso mundo. Elas especificam os objetos que nós podemos estudar (genes, desvios de personalidade, textos clássicos) e as relações que se obtém entre eles (mutação, criminalidade, canonicidade). Elas proporcionam critérios para o nosso conhecimento (verdade, significado, impacto) e métodos (quantificação, interpretação, análise) que regulam nosso acesso a ele.

Segundo, disciplinas produzem profissionais, o ortodoxo e o heterodoxo, o especialista e o generalista, o teórico e o experimental. Elas produzem veteranos circunspetos e iniciantes volúveis, conformistas e iconoclastas, inovadores e conservadores que povoam o bestiário acadêmico.

Terceiro, disciplinas produzem economias de valor. Elas produzem discursos em abundância: efêmeros ensaios para conferência, artigos arbitrados, sólidas monografias, livros premiados e discussões onipresentes. Elas produzem trabalho: catedráticos com dotações generosas, conferencistas com remuneração mínima, assistentes de graduação explorados. Elas asseguram recursos financeiros: financiamento de pesquisa, contratos, verbas para laboratórios, bolsas e salários. Elas garantem prestígio: distinções institucionais, avaliações departamentais, estrelato científico e acadêmico.

Finalmente, disciplinas produzem a idéia de progresso. Elas multiplicam objetos de estudo e aperfeiçoam explicações. Elas inventam noções que 
impõem ininterrupta adesão aceitação: a conservação de massa, a luta de classes, a ironia de Jane Austen. Elas contam estórias de progresso, mostrando como o conhecimento avança dentro das disciplinas existentes e pela criação de novas disciplinas." (Ibidem, p.vii-viii)

Entretanto, a forma disciplinar do conhecimento se apresenta em sua dupla identidade. Para Foucault ela é, ao mesmo tempo, forma de conhecimento e tecnologia de poder.

Com efeito, a partir dos séculos XVII e XVIII, a disciplina se tornou uma "fórmula de dominação": não mais pela custosa e violenta "apropriação dos corpos" como na escravidão; ou pela "dominação constante, global, maciça, não analítica, ilimitada e estabelecida sob a forma da vontade singular do patrão" da domesticidade; nem pela "submissão altamente codificada, [...realizada] sobre os produtos do trabalho e as marcas rituais da obediência" da vassalidade; tampouco pelo "ascetismo e das 'disciplinas' de tipo monástico" que visam realizar renúncias e o domínio sobre o próprio corpo (FOUCAULT, p.126-127).

Essa visão de disciplina se configura quando ela passa a visar não só o "aumento' das habilidades e "aprofundar" a sujeição" do corpo humano mas, sobretudo, "a formação de uma relação que no mesmo mecanismo o torna mais obediente quanto é mais útil, e inversamente". Estava nascendo uma "[...] política das coerções que são um trabalho sobre o corpo, uma manipulação calculada de seus elementos, seus gestos, de seus comportamentos", que é “igualmente uma 'mecânica do poder'”.

Ao mesmo tempo a disciplina aumenta e diminui as forças do corpo: faz deste uma aptidão e uma capacidade ("em termos econômicos de utilidade") e sujeição estrita ("em termos políticos de obediência). Nesse sentido "a coerção disciplinar estabelece no corpo o elo coercitivo entre uma aptidão aumentada e uma dominação acentuada" (Ibidem, p.127). 
Essa natureza essencial da disciplina, manifestada duplamente como forma e poder, vai constituindo aos poucos "um método geral" que se dissemina "pelos campos cada vez mais vastos, como se tendessem a cobrir o corpo social inteiro" (Ibidem, p.128). Organizações econômicas e sociais - escolares, hospitalares, militar, judiciária, industriais e quantas outras -, são reformuladas a partir da visão disciplinar, consolidando o que foi definido por Foucault como "poder disciplinar", e que também poderia ser chamado "disciplinaridade".

A característica desse poder é que, "em vez de se apropriar e de retirar, tem como função maior 'adestra'” ou que adestra "para retirar e se apropriar mais e melhor".

"Ele não amarra as forças para reduzi-las; procura ligá-las para multiplicálas e utilizá-las num todo. Em vez de dobrar uniformemente e por massa tudo o que Ihe está submetido, separa analisa, diferencia, leva seus processos de decomposição até às singularidades necessárias e suficientes. 'Adestra' as multidões confusas, móveis, inúteis de corpos e forças para uma multiplicidade de elementos individuais - pequenas células separadas, autonomias orgânicas, identidades e continuidades genéticas, segmentos combinatórios. A disciplina 'fabrica' indivíduos; ela é a técnica específica de um poder que toma os indivíduos ao mesmo tempo como objetos e como instrumentos de seu exercício. Não é um poder triunfante [...]; é um poder modesto, desconfiado, que funciona a modo de uma economia calculada, mas permanente. Humildes modalidades, procedimentos menores, se os comparamos [...] aos grandes aparelhos do Estado. E são eles justamente que vão pouco a pouco invadir essas formas maiores, modificar-Ihes os mecanismo e impor-Ihes seus processos. O sucesso do poder disciplinar se deve sem dúvida ao uso de instrumentos simples: o olhar hierárquico, a sanção normalizadora e sua combinação num procedimento que lhe é específico, o exame." (Ibidem, p.153) (grifo nosso) 
Esses traços de modéstia e humildade se afirmam por meio da vigilância hierarquizada - "uma das grandes 'invenções' técnicas do século XVIII e consolida o poder disciplinar como "um sistema 'integrado', ligado do interior à economia e aos fins do dispositivo onde é exercido" e "múltiplo, automático e anônimo". Essa vigilância se realiza como uma rede multidimensional e atinge a todos os indivíduos e em todas as direções: de alto para baixo, de baixo para alto e para os lados. Enfim, ela acaba por estabelecer um quadro em que todos vigiam e todos são vigiados.

"O que permite ao poder disciplinar ser absolutamente indiscreto, pois está em toda parte e sempre alerta, pois em princípio não deixa nenhuma parte às escuras e controla continuamente os mesmo que estão encarregados de controlar; e absolutamente 'discreto', pois funciona permanentemente e em grande parte em silêncio" (Ibidem, p.158). (grifo nosso)

Por outro lado, os objetivos e os resultados devem ser alcançados de forma sistemática e eficaz e a disciplina desenvolveu suas técnicas de poder para o controle dos indivíduos e de suas atividades. Os tempos e os espaços são segmentados e organizados em relações claramente estabelecidas e hierarquizadas, numa matriz que permita a otimização da vigilância hierárquica e da sanção normalizadora. (Ibidem, p.130 et.seq.).

Em termos do campo da educação, é esse poder disciplinar que está incubado na estrutura da universidade moderna, concebida por Humboldt e que se preservou até os dias de hoje.

A Universidade de São Paulo - USP, principalmente por ser de "pesquisa", é regida pelo poder disciplinar expressa na sua organização por disciplinas e departamentos.

Com efeito, para ela "a unidade de ensino é a disciplina". Entende-se, aí, a disciplina como "um conjunto sistematizado de conhecimentos afins" (USP, RG, Art.62) que compõem o currículo de cada um de seus cursos, 
tanto de graduação quanto de pós-graduação. Para obter grau acadêmico, ou seja, para concluir um de seus cursos e obter diplomas e certificados de conclusão desses cursos, o aluno necessita ser aprovado em todas as disciplinas que o integram (Idem, Art.63).

Por sua vez as disciplinas são ministradas pelo departamento, conceituado como a "a menor fração da estrutura universitária para os efeitos de organização didático-científica e administrativa" (USP, Estatuto, Art.51), o que significa que constitui a instância-meio para a realização dos fins da universidade: "promover e desenvolver todas as formas de conhecimento, por meio do ensino e da pesquisa"; "estender à sociedade serviços indissociáveis das atividades de ensino e de pesquisa"; "ministrar o ensino superior ...", aliás, em observância ao dispositivo constitucional que firma o "princípio de indissolubilidade entre ensino, pesquisa e extensão" (Art. 207).

Para tanto, ao departamento foi conferido todo o poder considerado necessário para cumprir a responsabilidade designada, reportando-se apenas às instâncias reguladoras e administrativas. Assim, a disposição estatutária (art.52) determina que cabe ao departamento:

"I elaborar e desenvolver programas delimitados de ensino superior;

II ministrar, isoladamente ou em conjunto com outros

Departamentos, disciplinas de graduação e pós-graduação;

III ministrar cursos de extensão universitária;

IV organizar o trabalho docente e discente;

V organizar e administrar os laboratórios;

VI promover a pesquisa;

VII promover a extensão de serviços à comunidade;

VIII encaminhar à Congregação, anualmente, o relatório das atividades dos docentes do departamento."

Por essa regulamentação, fica claro que o departamento - seja da USP ou o original da Universidade de Berlim - foi a forma e meio em que se 
institucionalizou a antiga disciplina (BURKE, p.86), revigorado no sentido de Foucault.

Nos departamentos podem ser identificados os procedimentos e as técnicas do poder disciplinar: a segmentação do conhecimento em conteúdos distribuídos e rearticulados hierarquicamente no tempo e no espaço, o poder fragmentado e discreto, a vigilância, a supervisão e, principalmente, o exame.

A propósito, para Hoskins e Macve, que teriam "ampliado" as idéias de Foucault (Vigiar e Punir), sustentam que foi na prática educacional que foi engendrada a visão disciplinar. Para eles, quando Foucault trata da emergência das relações entre o poder e o conhecimento, ele estaria se referindo ao ensino (p.29).

Além disso, Hoskin considera que o exame desempenhou papel principal na transformação nas relações poder-conhecimento, ao invés da posição de Foucault que vê essa mudança ocorrer num campo onde o exame se sobressai e a educação é um campo entre muitos outros. A partir dessa perspectiva, Hoskin reivindica que o poder do conhecimento e o poder disciplinar é constituído por: "1) exame constante e rigoroso; 2) avaliação numérica; 3) um insistente processo de escrita pelos estudantes, sobre estudantes e organizacionalmente em torno dos estudantes" (p.272).

De qualquer maneira, foi no campo do ensino que as técnicas do poder disciplinar se realizaram de modo mais completo: as atividades de seus protagonistas, os professores e os alunos, estão organizados de maneira expressamente disciplinar através da "grade curricular".

Primeiro se divide a "duração em segmentos, sucessivos ou paralelos, dos quais cada um deve chegar a um termo específico"; depois se organiza essas seqüências "segundo um esquema analítico - sucessão de elementos tão simples quanto possível, combinando-se segundo uma complexidade crescente"; por último, para finalizar esses segmentos temporais, "fixar-lhes um termo marcado por uma prova", para verificar 
"se o indivíduo atingiu o nível estatutário, de garantir que sua aprendizagem está em conformidade com a dos outros, e diferenciar as capacidades de cada indivíduo" (FOUCAULT, p.143). Essas etapas serão vencidos pelo procedimento disciplinar visando a "economia das atividades e o controle orgânico", o "exercício" - "técnica pela qual se impõe aos corpos tarefas ao mesmo tempo repetitivas e diferentes, mas sempre graduadas" que permite uma contínua avaliação do indivíduo em relação ao objetivo estabelecido, aos companheiros ou a um tipo de percurso. (FOUCAULT, p.145-146).

É o "tempo disciplinar" que se impôs à prática pedagógica:

"organizando diversos estágios separados uns dos outros por provas graduadas; determinando programas, que devem desenrolar-se cada um durante uma determinada fase, e que comportam exercícios de dificuldade crescente; qualificando os indivíduos de acordo com a maneira como percorrem essas séries. O tempo 'iniciático' da formação tradicional (tempo global, controlado só pelo mestre, sancionado por uma única prova) foi substituído pelo tempo disciplinar com suas séries múltiplas e progressivas. Forma-se toda uma pedagogia analítica, minuciosa (decompõe até aos mais simples elementos a matéria de ensino, hierarquiza no maior número possível de graus cada fase do progresso) [...]" (Ibidem, p.144). (grifo nosso)

Desse modo, em cada um desses segmentos, que também eram segmentos do espaço curricular e do espaço físico que constituíam a "unidade de ensino", ou seja em cada "disciplina" se instalou o poder necessário para controlar os procedimentos do poder disciplinar, especialmente o do "exame" Aliás, como estabelecido formalmente: "a avaliação do rendimento escolar do aluno será feita em cada disciplina em função de seu aproveitamento verificado em provas e trabalhos decorrentes das atividades previstas ..." (USP, RG, Art.81). 
Para Foucault, o exame constitui a brilhante "cerimônia do poder e a forma da experiência, a demonstração da força e o estabelecimento da verdade", por isso, um ato "altamente ritualizado". É um dispositivo disciplinar em que se combinam as técnicas da vigilância hierárquica e a sanção normalizadora para "qualificar, classificar e punir" para ostentar a "sujeição dos que são percebidos como objetos e a objetivação dos que se sujeitam" (p.164-165).

Não é, portanto, de surpreender, o poder que as disciplinas conquistaram, a partir da estrutura proposta por Humboldt, transformando-se de simples "unidade de ensino" em verdadeiras "unidades de poder" dentro da estrutura universitária moderna.

Entretanto, o poder disciplinar não é exclusivo da disciplina enquanto espaço didático. Da mesma maneira que o ensino, a pesquisa constitui campo de exercício do poder disciplinar, até mais importante. De fato, a vocação da ciência, já intuída por Humboldt, em ser "um problema que nunca pode ser totalmente resolvido" que transforma a pesquisa "num esforço infinito" (p.81), faz desse campo o solo fértil para a germinação de novos caminho e fronteiras do conhecimento, em grande parte como subdivisões e especializações, e, portanto uma pressão para a criação de novas disciplinas dentro da estrutura universitária.

Esse processo pode ser ilustrado com dois exemplos. Levantamento elaborado pelo $\mathrm{MEC}^{43}$ em 31 escolas de arquitetura e publicado em 1978 já contabilizava 2006 disciplinas agrupadas em 49 matérias, mesmo considerando que tenham sido incluídas aquelas com conteúdos próximos mas com denominações diferentes. A pesquisa de autoria de Julie Thompson Klein, divulgada em 1994 no $1^{\circ}$ Congresso Mundial da Transdisciplinaridade, realizado em Portugal, registrava um total de 8.530, campos de conhecimento, ou disciplinas, com a oportuna observação de

\footnotetext{
${ }^{43}$ BRASIL. Ministério da Educação e Cultura. Departamento de Assuntos Universitários. Comissão de Ensino de Arquitetura e Urbanismo. Catálogo geral das disciplinas dos cursos de arquitetura e urbanismo. Brasília: 1978.
} 
que esse número continuava a se ampliar "em desenvolvimentos complexos, híbridos, não lineares, heterogêneos" ${ }^{\text {"4 }}$.

Esses números confirmam a natureza do poder disciplinar voltada permanentemente para o fragmento e para o detalhe, o que conduz às definições de Foucault como "uma anatomia política do detalhe", um poder onipresente que controla "as mínimas parcela da vida e do corpo" e que constrói o que ele chamou de uma "nova 'microfísica' do poder"' (p.128-129).

44 DOMINGUES, Ivan (org.). Conhecimento e transdisciplinaridade. Belo Horizonte: Editora UFMG, 2001. p.37. 


\subsection{Disciplinaridade e projeto}

A organização disciplinar da universidade

Para efeito das considerações que se seguem, é necessário estabelecer a distinção entre as acepções com que deve ser entendido o uso do termo "disciplina". Para designar o poder disciplinar no sentido de Foucault, o termo será grafado "Disciplina" com inicial em maiúscula. Será escrita "disciplina" com minúsculas quando indicar as "unidades de ensino" como foi definido pela USP. Como um equivalente de Disciplina, com o sentido de poder disciplinar, será usado também o termo "disciplinaridade".

A análise da questão da disciplinaridade permitiu mostrar que a disciplina é Disciplina e, ao mesmo tempo, seu fragmento e o meio através do qual se revela e se realiza enquanto poder. Nesse sentido, a disciplina é poder e mecanismo do poder disciplinar e, assim, integra as estruturas de poder crescentemente maior. Sua instância imediatamente superior é o departamento e o topo da pirâmide seria o que Foucault chamou de "sociedade disciplinar' e a própria Disciplina que a organiza.

Por sua vez, numa escola, no caso uma instituição de ensino superior ${ }^{45}$ estrutura de poder baseado no domínio de um corpo de conhecimento organizado em função de um objeto e um fim, o currículo - cada instância didática detém a parcela desse corpo de conhecimento e a parcela de poder correspondente, num processo de segmentação e recomposição hierárquica como caracterizado por Foucault. Assim, cada departamento detém o seu conteúdo, e cada disciplina do departamento uma parcela desse conteúdo, necessariamente parcelar.

\footnotetext{
${ }^{45}$ Preferencialmente, instituições de ensino superior públicas, nas quais essa
} estrutura se realiza de forma mais típica. 
Nessa medida é que a disciplina, como a "menor unidade de ensino" é também a "menor unidade de poder" dentro da hierarquia porque detém o menor fragmento do conteúdo curricular. Inversamente, a perda de conteúdo significa perda de poder.

Observe-se, de outra parte, na medida em que o currículo é constituído de conteúdos pré-estabelecidos, normalmente os conteúdos dos departamentos e das disciplinas são também pré-estabelecidos. Por essa razão, a estrutura disciplinar é, em princípio, estável e harmônica, mas sua estabilidade pode ser perturbada em algumas circunstâncias.

Conflitos disciplinares

Como o poder da disciplina é emanado pelo conteúdo que detém, o poder de uma disciplina ou de disciplinas que detêm conteúdos afins é diretamente proporcional ao poder desses conteúdos, que se constitui qualitativa e quantitativamente: disciplinas que têm conteúdos maiores e poder proporcional mantém segmentos maiores do tempo para o ensino, que é a forma em que se opera seus conteúdo - horas de aula, carga didática -; por sua vez, o que determina o domínio de tempos maiores é o prestígio ou a importância dos conteúdos, entendido que esse prestígio é determinado socialmente. No caso da arquitetura, algumas disciplinas se destacam das demais exatamente porque detém conteúdos de maior prestígio por seu nível de importância socialmente atribuído - edificações e cidade, como exemplos. O desequilíbrio ocorre quando essa escala de prestígio é alterada por força de mudanças ocorridas no cenário externo, fato que acarreta naturalmente o rearranjo da relação de poder no plano interno: disciplinas ganharão conteúdo e poder, outras perderão, uma vez que o tempo disponível para o ensino é limitado, na medida do tempo correspondente aos conteúdos fixos do departamento e ao da escola como um todo, circunstâncias que podem provocar distúrbios no equilíbrio interno, o que conflita com o princípio de estabilidade do corpo disciplinar. 
A disciplina e seus operadores

O agente que opera o conteúdo disciplinar no ensino é, fundamentalmente, o professor. Mas, o professor não exerce diretamente o poder da disciplina, tanto que, diferentemente da cátedra, o professor não detém o conteúdo, que está intrinsecamente vinculado à disciplina: a disciplina fica e o professor pode ser substituído, removido. Por outro lado, a disciplina também não depende do prestígio do professor, e viceversa: o prestígio pessoal do professor não the confere poder. Por essa razão nessa estrutura, na raiz de eventual conflito entre professores, está o conflito entre disciplinas ${ }^{46}$

O ensino

O ensino é a forma de operação do conteúdo por meio da qual o poder da disciplina é exercido no interior da estrutura educacional. Sendo os procedimentos disciplinares sempre orientados para a ao eficácia, o ensino ganha eficiência sendo como transmissão de conhecimentos ou sendo a exercitação de habilidades, desde que constituam conteúdos segmentados.

A organização do ensino - a operação desses conteúdos - se faz de maneira exemplarmente disciplinar: subdividem-se o conteúdos e os tempos em segmentos - cada segmento é atribuído a uma disciplina, rearticulam-se e distribuem-se esses segmentos no tempo e no espaço (numa disposição expressa na familiar "grade-curricular"): cada conteúdo

\footnotetext{
${ }^{46}$ Foi o que aconteceu, por exemplo, na reestruturação do Departamento de Projeto da FAUUSP, EM 1997: a perspectiva de diminuição da carga horária aprovada em primeira instância foi contestada e a carga retirada de um grupo de disciplinas teve que ser restituída para a aprovação da proposta final. $\mathrm{Na}$ realidade, não se tratava de uma redução real do tempo do grupo de disciplinas: o que se propunha era a desvinculação do conteúdo desse grupo, mas mantendo-se o conteúdo que seria acessível a outros grupo. De qualquer maneira, configurava flagrante afronta aos princípios disciplinares em vigiencia.
} 
no seu horário e no seu lugar. Nesses segmentos se aplicam os exercícios em grau de complexidade crescente e se aplicam exames para avaliar os desempenhos em relação aos objetivos de cada segmento, visando uniformizar o aprendizado, e diferenciar as capacidades individuais.

O ensino de projeto na estrutura disciplinar

Para Barreto, a arquitetura caracteriza-se por seu caráter de aplicação: é uma "disciplina de aplicação, é conhecimento universitário, mas não é conhecimento sobre algo (... o arquiteto não é cientista), mas conhecimento aplicado a algo, com vistas a gerar algo" (BARRETO, p.64).

De fato, arquitetura gera um espaço novo e para tanto necessita de conhecimentos, isto é, não trabalha só com um segmento de conhecimento ou com um único conteúdo disciplinar. Ao contrário, mobiliza múltiplos conteúdos conforme necessidade para gerar um espaço.

Além disso, o procedimento que capacita o arquiteto a gerar espaços é o projeto, uma atividade e habilidade fundamentalmente de síntese.

Nessa medida a atividade de projeto, mesmo como treinamento, não se compatibiliza com a estruturas disciplinares, fundamentalmente de análise. Ou seja, o ensino de projeto necessita de uma estrutura não disciplinar. 


\section{Conclusão}

Este trabalho procurou confirmar o caráter disciplinar da estrutura das escolas em que se processa o ensino de arquitetura. Isso significa que as escolas são, no dizer de Foucault, uma forma de organizar o conhecimento - transmite, produz, divulga, mas também é uma forma de poder. São, de fato, mecanismos do poder disciplinar, poder de dominação, são estruturas marcadas pelos procedimentos eficazes que os exercem, com o objetivo básico de adestrar. Como foi visto, é um poder onipresente, permanente mas discreto, pois funciona "em grande parte em silêncio" (FOUCAULT, p.158). Por essa razão é um poder que não é aparente nas escolas, pois que poucos devem conhecer seus mecanismos, seu funcionamento. Dessa forma, mesmo o nome "disciplina", quase sinônimo de ensino, aparece apenas como um componente operacional do sistema educacional, sem revelar a sua natureza como forma de poder.

Esta é a primeira dificuldade a ser considerada por aqueles que pensam o ensino e, principalmente por aqueles que imaginam poder mudar o ensino. Esse cuidado é ainda mais necessário nos casos em que o ensino enfrenta obstáculos interpostos por essa forma de organização, e é o caso do ensino de projeto que, como foi visto, não consegue se exercitar dentro da estrutura disciplinar.

Recapitulando, a incompatibilidade do ensino de projeto com essa estrutura, se dá em três níveis: o projeto se baseia na operação por síntese e a Disciplina, por análise; o projeto compõe conteúdos, a Disciplina decompõe conteúdos; o projeto tem um conteúdo aberto a constituir, a Disciplina conteúdo fechado, pré-estabelecido, instituído. Com efeito, a arquitetura, enquanto "aplicação", tem na síntese o princípio 
que conduz a habilidade de compor e recompor os conteúdos fragmentários das disciplinas para constituir o conteúdo, isto é, os conhecimentos necessários para "gerar" um "algo" que é uma nova forma espacial. Nessas condições, o projeto não se compatibiliza com uma estrutura em que o principio seja de análise, opere por decomposição e o conteúdo seja único, pré-estabelecido, fragmentado.

Ao contrário, o espaço do projeto é o da não disciplinaridade e é nessa medida que se configura sua incompatibilidade com os espaços da disciplinaridade das escolas de arquitetura atuais, mesmo que o chamem de "ateliê", que, aliás, recebeu a missão impossível de se tornar o espaço do projeto dentro das regras da disciplinaridade.

E também não se alimenta nenhuma ilusão de que a escola de arquitetura, antes de ser de projeto, seja escola no sentido pleno do mecanismo do poder disciplinar. É evidente que a estrutura educacional é eficaz em termos de treinamento e adestramento e, dentro dessa sociedade disciplinar, uma instituição imprescindível.

Por outro lado, não se pretendeu, pelo menos aqui, questionar a existência de tais mecanismos de poder. Nem aqui se buscam outros espaços educacionais, não escolares, para a arquitetura ou para qualquer outro ramo do saber e de atividade, ou outros poderes ou não-poderes, não disciplinares. Que há os que já os buscam, por exemplo, os que propõem a transdisciplinaridade, Edgar Morin à frente.

O que se coloca aqui é apenas que o exercício do projeto se faça de acordo com as necessidades de uma atividade claramente incompatível com a estrutura disciplinar, e o presente trabalho pretendeu ter mostrado que é possível construir espaços para o projeto mesmo dentro da estrutura disciplinar das atuais escolas de arquitetura. Espaços que certamente não serão disciplinares e que também não deverão ser inter ou multidisciplinares, porque antes de ser inter e multi, já são disciplinares. Talvez, um espaço não disciplinar, simplesmente. 
Exemplos foram lembrados para mostrar que isso é possível. Mas, para isso é necessário que essa estrutura e o caráter da disciplinaridade sejam desvelados, seu funcionamento conhecido por trás das inocente grades curriculares povoadas de quadradinhos com as suas disciplinas. 


\section{Referências bibliografias}

ARANTES, Pedro Fiori. Arquitetura Nova: Sérgio Ferro, Flávio Impeerio e

Rodrigo Lefèvre, de Artigas aos mutirões. São Paulo: Editora 34, 2002. ARTIGAS, João Batista Vilanova.

- $\quad$ Caminhos da Arquitetura. São Paulo: LECH, 1981.

- $\quad$ ALBUQUERQUE, Roberto Portugal (coord.). Caderno dos riscos originais: projeto do edifício da FAUUSP na Cidade Universitária. São Paulo, FAUUSP, 1998.

- $\quad$ A função social do arquiteto. São Paulo: Nobel, 1989.

- $\quad$ Contribuição para o relatório sobre ensino de arquitetura. UIAUNESCO. Sinopses Memória, São Paulo, 1993, p.133-137.

Edição especial

BURKE, Peter. Uma história social do conhecimento: de Gutenberg a Diderot.

Rio de Janeiro, Jorge Zahar Editor, 2003.

CEZAR, Roberto de Cerqueira. O ensino da arquitetura e urbanismo Relatórios. In: MILAN, p.8-33.

CHAUÍ, Marilena de Souza. Escritos sobre a universidade. São Paulo: Editora UNESP, 2001.

- $\quad$ A reforma do ensino. Revista Discurso, n8, 1977.

COMISSÃO DE REESTRUTURAÇÃO CURRICULAR. Relatório 1977. São Paulo: FAUUSP, 1977.

COSTA, Eliane Marta Teixeira, FARIA Filho, Luciano Mendes de e VEIGA, Cynthia Greive (orgs.). 500 anos de educação no Brasil. Belo Horizonte: Autêntica, 2000.

DAHER, Luiz Carlos. O espaço arquitetônico brasileiro dos últimos 20 anos e a formação profissional do arquiteto. Sinopses Memória, São Paulo, 1993, p.156-165. Edição especial.

DENTE, Edgar Gonçalves. Proposta apresentada pelo professor. In: FAUUSP-c, Vol.2, s.p.

ENSINO e currículo na FAU: propostas para o fórum de agosto. In: FAUUSP-c, Vol.2, p.37-74. 
FAGGIN, Carlos. O ateliê na formação do arquiteto: uma análise critica do documento apresentado por Carlos Millán na FAUUSP, em 1962.

Sinopses Memória, São Paulo, 1993, p.130-132. Edição especial. FAUUSP.

- a Fundamentos econômicos e sociais da profissão do arquiteto. São Paulo, s.d. / Mimeografado /

- b Relatório sobre o ensino de arquitetura no Brasil. UIA-UNESCO. Sinopses Memória, São Paulo, 1993, p.144-155. Edição especial.

- c Conclusões dos I, II, e III encontros de diretores e estudantes de arquitetura em Belo Horizonte 1960, Salvador 1961 e São Paulo 1962. São Paulo, FAUUSP, 1962.

- d Departamento de Projeto. Proposta de reestruturação curricular para 1999. São Paulo, 1997 / Mimeografado /

- e Propostas apresentadas à Comissão curricular: 1978. São Paulo: FAUUSP, 1978. Vol. 1 e 2.

FAUUSP/MUSEU. Fórum de 1969: relatório Museu FAU. São Paulo: FAUUSP, 1969.

FARIA, Ernesto. Vocabulário latino-português. Rio de Janeiro: F.Briguet, 1943.

FERRO, Sérgio. Depoimento. In: SANTOS, Maria Cecília Loschiavo. Maria Antonia: uma rua na contramão. São Paulo; Nobel, 1988.

FERNANDES, Ari Vicente et alii. Prática - Investigação. In: IX CONGRESSO BRASILEIRO DE ARQUITETOS, São Paulo, 1976. Anais. São Paulo, IAB-SP, 1976.

GOUVÊA, Luiz Alberto de Campos, BARRETO, Frederico Flósculo Pinheiro e GOROVITZ, Matheus (orgs.). ContribuiContribuição ao ensino de arquitetura e urbanismo. Brasília: Instituto Nacional de Estudos e Pesquisas Educacionais, 1999.

KATAKURA, Paula. O ensino de projeto de arquitetura. São Paulo, 2003, 298p. Tese (Doutorado) - Faculdade de Arquitetura e Urbanismo, Universidade de São Paulo.

KOURY, Ana Paula. Grupo Arquitetura Nova. São Paulo: 1999. Dissertação (Mestrado) - Faculdade de Arquitetura e Urbanismo, Universidade de São Paulo.

LIMA, Mayumi Watanabe de Souza; LIMA, Sérgio de Souza (org.). Arquitetura e educação. São Paulo: Studio Nobel, 1995. 
LOPES, Eliane Marta Teixeira, FARIA FILHO, Luciano Mendes de e VEIGA, Cynthia Greive, (orgs.). 500 anos de educação no Brasil. Belo Horizonte: Autêntica, 2000.

MESSER-DAVIDOW, Ellen, SHUMWAY, David R. e SYLVAN, David J. (edits.). Knowledges: historical and critical studies indisciplinartity. Charlottesville e Londres: University Press of Virginia, 1993.

MILLÁN, Carlos Barja (Coord.). O ateliê na formação do arquiteto. São Paulo: FAUUSP, 1962.

MONGELLI, Lênia Márcia (coord.). Trivium e quadrivium: as artes liberais na Idade Média. Cotia (SP): Íbis, 1999.

MOTTA, Flávio. Subsídios para o relatório sobre ensino de arquitetura UIAUNESCO. Sinopses Memória, São Paulo, 1993, p.138-143. Edição especial.

OLIVEIRA, Maria Rita Neto Sales (org.). Confluências e divergências entre didática e currículo. Campinas, SP: Papirus, 1998.

OLIVEN, Arabela Campos. Resgatando o significado do departamento na universidade brasileira. In: MARTINS, Carlos Benedito (org.). Ensino superior brasileiro; transformações e perspectivas. São Paulo:

Brasiliense, 1989.

PEREIRA, Miguel.

- a Arquitetura e os caminhos de sua explicação. São Paulo: Projeto Editores associados, 1984.

- b Arquitetura: cultura, formação, prática e política profissional. São Paulo: Pini, 2005.

PIOTROWSKI, Andrzej e ROBINSON, Julia Williams (eds.). The discipline of architecture. Minneapolis e Londres: University of Minnesota Press, 2001.

PRADO, Luiz Cintra do. Tendências no ensino de arquitetura. Aula inaugural na Faculdade de Arquitetura e Urbanismo, USP, 12 de março de 1964. São Paulo: FAUUSP, 1964. (transcrito do "Digesto Económico", n 177, maio/junho, 1964). (datilografao)

PROPOSTA apresentada por um grupo de alunos dos $3^{\circ}$ e $5^{\circ}$ anos. In: FAUUSP-c, Vol 1, p.13-34.

SANTOS, Lucíola de Castro Paixão e OLIVEIRA, Maria Rita Neto Sales. Currículo e didática. In: OLIVEIRA, M., p.7-32.

YURGEL, Marlene, Arquitetura paulista - 1952/92. 40 anos de contribuição dos arquitetos formados na FAUUSP. Sinopses Memória, São Paulo, 1993, p.124- 129. Edição especial. 
ZANETTINI, Siegbert. O ensino de projeto na área de edificação. São Paulo: FAUUSP, 1980.

\section{Anais e catálogos de exposição}

“100 ANOS DE ENSINO DE ARQUITETURA E URBANISMO EM SÃO PAULO”, FAUUSP, REIS, Nestor Goulart (coord.), São Paulo, Museu da Casa, Brasileira, Catálogo de Exposição, 1996.

IX CONGRESSO BRASILEIRO DE ARQUITETOS, São Paulo, 1976. Anais. São Paulo, IAB-SP, 1976.

\section{Periódicos}

SINOPSES MEMÓRIA. São Paulo: FAUUSP, 1993. Edição especial. , 2005, p.114). 


\section{Bibliografia}

ABBOTT, Andrew Delano. The system of professions: an essay on the division of expert labor. Chicago e Londres: The University of Chicago Press, 1988.

APPLE, Michael W. Ideologia e currículo. Porto Alegre: Artmed, 2006.

BENÉVOLO, Leonardo. História da arquitetura moderna. São Paulo: Perspectiva, 1976.

CARREIRA, Eduardo. "Limites e grandezas do pensamento geométrico na Idade Média". In: MONGELLI (coord.), p.203-247.

CHAFEE, Richard. "The teaching of architecture at the Ecole des Beaux-

Arts". In: DREXLER, p.61-109.

COMAS, Carlos Eduardo Dias. "Ideologia modernista e ensino de projeto arquitetônico: duas proposições em conflito". In: COMAS (org.), p.33-45.

CORONA Martinez, Alfonso. "Crise e renovação no ensino do projeto em arquitetura". In: COMAS (org.), p.85-94.

COSTA, Lucio.

- $\quad$ Arquitetura. Rio de Janeiro: José Olympio, 2002.

- $\quad$ Lúcio Costa: registro de uma vivência. São Paulo: Empresa das Artes, 1995.

CUFF, Dana. Architecture: the history of practice. Cambridge, Massachusetts: MIT Press, 1992.

CUNHA, Luiz Antônio. "Ensino superior e universidade no Brasil". In: LOPES, FARIA FILHO e VEIGA, (orgs.), p.447-468.

CZAJKOWSKI, Jorge. "Arquitetura brasileira: produção e critica". In: COMAS (org.), p.9-13.

DÍAZ, Antonio et alii. Cursos de Arquitetura 1976 - 1981. La Escuelita. 5 anõs de enseñanza alternativa de arquitectura en la Argentina. Buenos Aires:

Espacio,1981.

DRAPER, Joan. "Le Ecole de Beaux-Arts y la profesión de arquitecto en los Estados Unidos: el caso de John Galen Howard". In: KOSTOF, p.201226.

DREXLER, Arthur (ed.). The architecture of the Ecole des Beaux-Arts. Cambridge: Massachusetts, The MIT Press, 1977. 
DUFREENE, Mikel. A estética e as ciências da arte. Amadora, Portugal:

Bertrand, 1982.

DURAND, Carlos Garcia. A profissão de arquiteto (estudo sociológico). Rio de Janeiro: CREA 5a Região, 1974.

EGBERT, Donal Drew. The Beaus-Arts traditions in French. Princeton:

Princeton University Press, 1980.

FICHER, Sylvia. Os arquitetos da Poli: ensino e profissão em São Paulo. São Paulo: Fapesp e Edusp, 2005.

FERRIS, Roger. Introduction. In: SAUNDERS, William S. (ed.). Reflections on Architectural Practices in the Nineties. Nova York: Princeton Architectural Press, 1996.

FURLANI, Lúcia Teixeira. A claridade da noite: os alunos do ensino superior noturno. São Paulo: Cortez, 1998.

GRAEFF, Edgar A. Arte e técnica na formação do arquiteto. São Paulo: Nobel, 1 995.

HAUTECOEUR, Louis. Révolution et Empire. Paris: A. et J. Picard, 1953.( Histoire de l'architecture classique en France, v.5)

KATINSKY, Júlio Roberto. Ensinar e aprender: por uma educação criadora. In: GOUVÊA, BARRETO e GOROVITZ, p.7-30.

KOSTOF, Spiro.

- (coord.). El arquitecto: historia de una profesión. Madrid: Cátedra, 1984.

- a. "El ejercício de la arquitectura en el mundo antiguo: Egito e Grécia”. In: KOSTOF, p.13-34.

- b. El arquitecto en la Edad Media, en Oriente y Occidente". In: KOSTOF, p.65-98

KRAUSE, Elliot A. Death of guilds: professions, states, and the advance of capitalism, 1930 to the present. New Haven e Londres: Yale University Press, 1996.

MACDONALD, William L. "Los arquitectos romanos". In: KOSTOF, p.35-64.

MAHFUZ, Edson da Cunha. "Os conceitos de polifuncionalidade, autonomia e contextualismo e suas conseqüências para o ensino de projeto arquitetônico". In: COMAS (org.), p.47-68.

OLIVEIRA, Rogério de Castro. "A formação do repertório para o projeto arquitetônico: algumas implicações didáticas". In: COMAS (org.), p69-84.

OLMOS, Susana Acosta. Ética e estética no ensino de projeto: práticas atuais nos ateliês da FAUUFBA. Salvador, 2004, 372p. Tese (Doutorado) Faculdade de Arquitetura e Urbanismo, Universidade Federal da Bahia.

PATETTA, Luciano. Historia de la Arquitetura. Antologia crítica. Madrid: Hermann Blume, 1984. 
PAULA, Maria de Fátima de. A modernização da universidade e a transformação da intelligentzia universitária. Florianóplis: Insular, 2002.

ROSENFELD, Myra Nan. "La real administración de Edifícios en Francia, de Carlos V a Luis XIV". In: KOSTOF, p.159-174.

SAUNDERS, William S. (ed.). Reflections on architectural practices in the nineties.Nova York: Princeton Architectural Press, 1996

QUEIROZ, Terza Aline Pereira de. "Aprender a saber na Idade Média”. In: MONGELLI (coord.), p.9-31.

SEGNINI Jr., Francisco. A prática profissional do arquiteto em discussão. São Paulo, 2002, 238p. Tese (Doutorado) - Faculdade de Arquitetura e Urbanismo, Universidade de São Paulo.

SILVA, Elvan. "Sobre a renovação do conceito de projeto arquitetônico e sua didática". In: COMAS (org.), p.15-31.

SILVEIRA, Roberto Py Gomes. O ensino de arquitetura na UFRGS: um documento para debate. Porto Alegre: URFGS / Faculdade de Arquitetura, 1984..

USP. O espaço da USP: presente e futuro. São Paulo: Universidade de São Paulo, Prefeitura da Cidade Universitária "Armando de Salles Oliveira", 1985.

WILKINSON, Catherine. "EI nuevo profesionalismo en el Renacimiento". In: KOSTOF, p.159-176. 